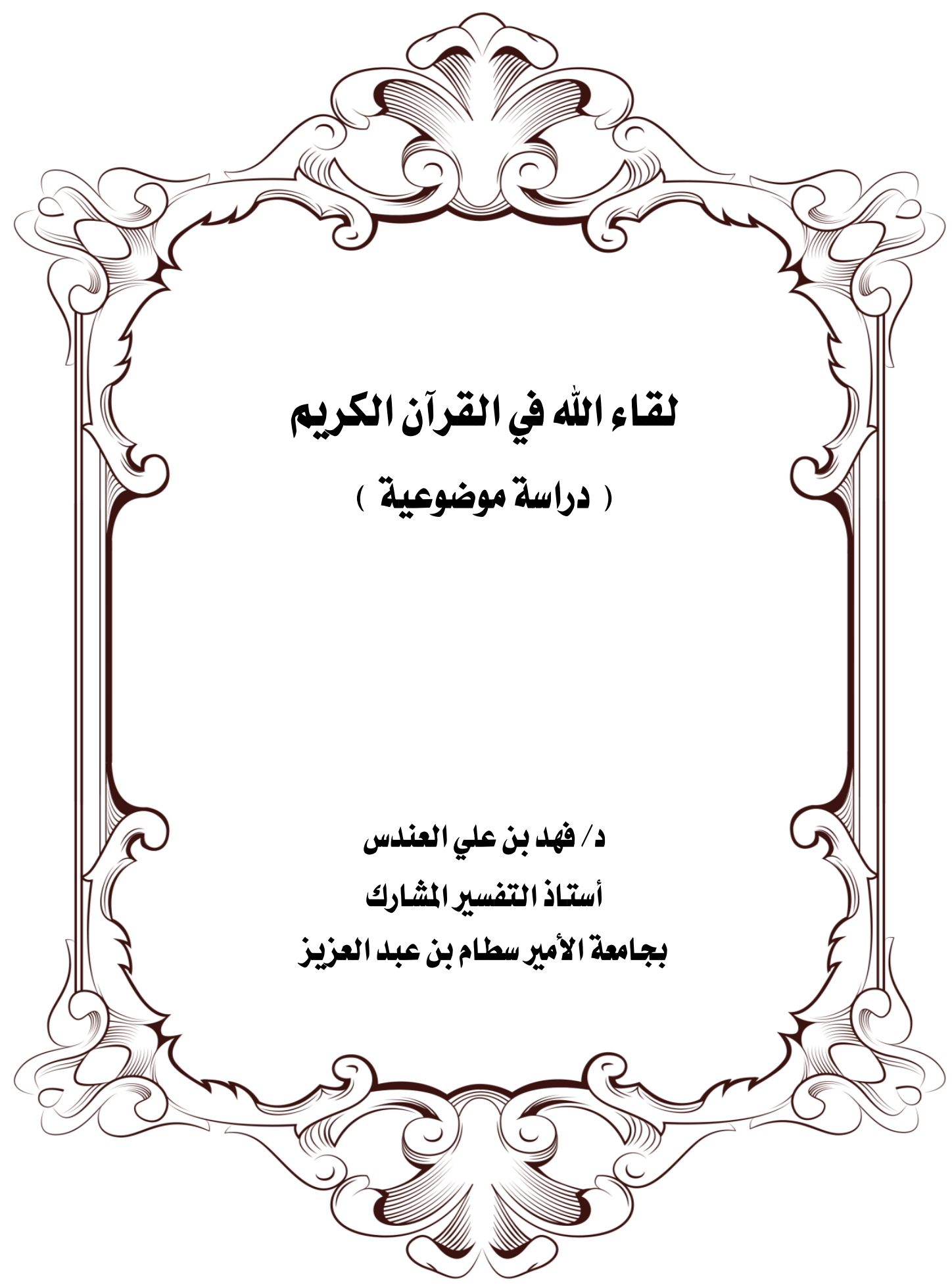


لقاء الله في القرآن الكريم ( دراسة موضوعية )

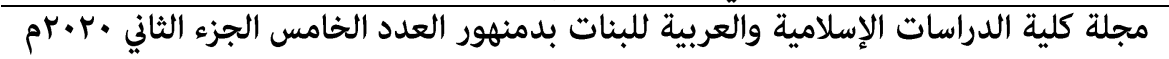




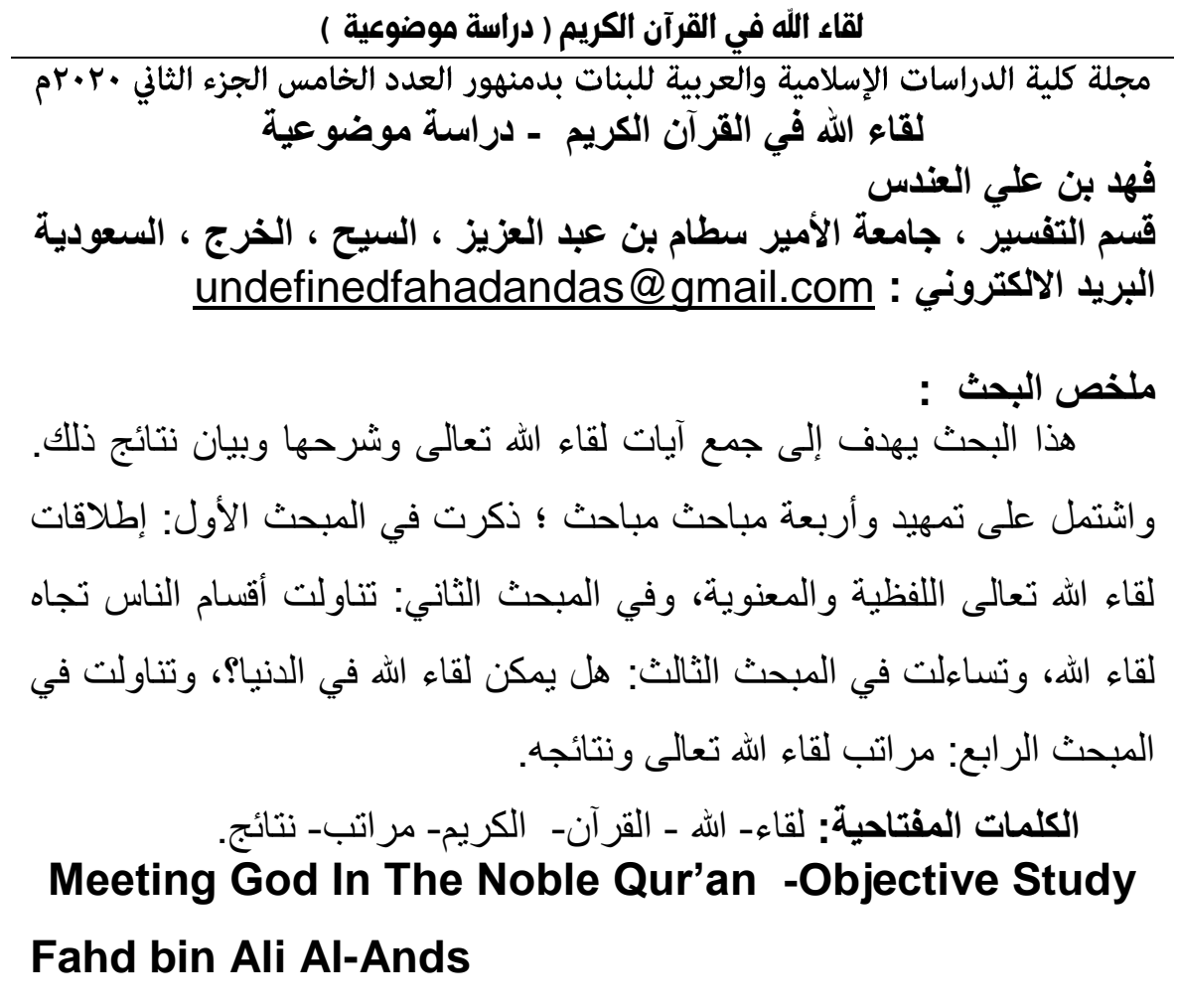

Interpretation section ,Prince Sattam bin Abdulaziz University, Seh. The output. Saudi

\section{E-mail: undefinedfahadandas@gmail.com}

\section{Abstract :}

This research aims to collect and explain the verses of God Almighty and explain the results of that. It included a preamble and four mabahith investigations, mentioned in the first topic: verbal and moral releases of God Almighty, and in the second topic: I dealt with sections of people towards meeting God, and I asked in the third topic: Is it possible to meet God in the world ?, and dealt in the fourth topic: ranks of meeting God Almighty and its consequences

Keywords: Meeting , God, The Qur'an, The Holy , Ranks, Results 


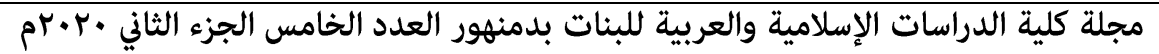

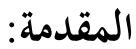

الحمد لله رب العالمين، والصلاة والسلام على أشرف المرسلين، سيدنا محمد خاتم الأنبياء والمرسلين، وعلى آله وصحبه أجمعين، ومن تبعهم بإحسان إلى يوم

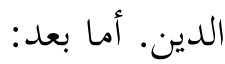

فإن من رام لقاء الله يمتاج إلى الاجتهاد في الطاعة، والعمل الصالح،

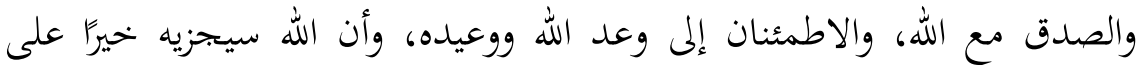
طاعته، والامتثال لأوامره. إن الموت حقيقة لا شك فيه، وأن كل إنسان سيقف أمام ربه سبحانه ليحاسبه على ما قدم في حياته، ولكن اللقاء يختلف من إنسان لأخر، فالذي قدم صالحًا، واطاع ربه، يتمنى أن يلقى الله، ويسعد بنعيمه، قال تعالى:

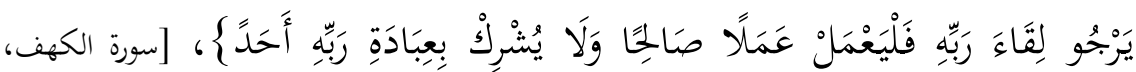
الآية (·11)]. والذي أطاع هواه، واتبع شهواته، وجعل الدنيا في قلبه، كره لقاء الله؛ لشدة الموقف عليه، وما يلقاه من عقاب.

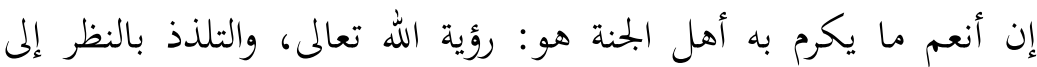

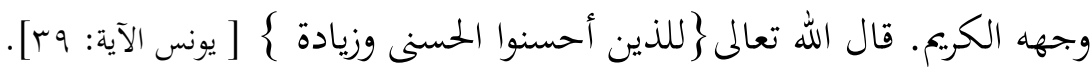
أهمية الموضوع وسبب اختياري له: أولا: أهمية الموضوع: تتتجلى أهمية الموضوع : فيما يلي: أموضوح () إن لقاء الله والرجوع إليه هو مصير كل المخلوقات؛ فدراست ذلك وبيان أنواعد مما يهم طالب العلم.

Y) إن لقاء الله يتضمن رؤيته سبحانه، فمعرفة ما يقرب إلى الله للسير عليه، وما يغضب الله للبعد عنه محا بتحدر دراسته والبحث فيه. ب) مراتب وأنواع لقاء الله في القرآن الكريم، كثير ومتشعبة، ورسم ذلك وبيانه في دئه سمت واحد محا يفيد طالب العلم، ويعين المسلم على السير والفرار إلى الله تعالى، كل ذلك يحتم البحث والدراسة في هذا الموضوع. 


\section{لقاء الله في القرآن الكريم ( دراسة موضوعية )}

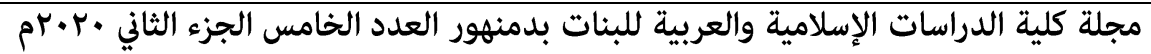

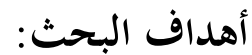

( ) توضيح الفرق بين لقاء الله وبين نزوله سبحانه وتعالى.

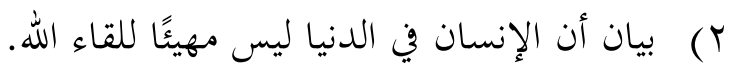
ب) توضيح الحلاف بين أهل السنة وخخالفيهم في قضية رؤية الله تعالى.

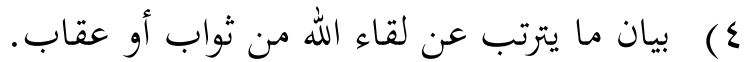
منهج البحث: وأمَّا عن المنهج المتبع في هذه الدراسة فقد اقتضت طبيعة البحث على أن يكون المنهج المتبع هو المنهج الاستقرائي والتحليلي. المنهج الاستقرائي: من أجل حصر الآيات القرآنية التي تتناول الحديث عن لقاء الله، ورؤيته في الآخرة. المنهج التحليلي: بعد استقراء هذه الآيات والذي من خلاله يقوم الباحث بتوضيح وتحليل ما احتوت عليه الآيات القرآنية من مراتب اللقاء بين العبد وربه بعد موته، أو في الآخرة.

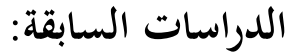

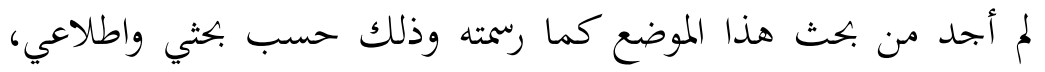
وهناك دراسات قريبة من هذا الموضوع، ولما صلة به من طرف خفي، ولكنها ليست ذات الموضوع، ولا درست جميع ما يرمي إليه الباحث في بحثه، ومن تلك الدراسات: الشوق إلى لقاء الله، قام بإعداده الطالب: المراكبي، جمال. وهو بحث نشر بمقر جماعة أنصار

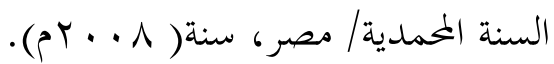
لقاء الله عز وجل بين السلف ومخالفيهم لمحد بن إبراهيم العجلان. بحث محكم نشر بمجلة الدراسات العربية، جامعة المنيا- كلية دار العلوم، يونيو $\cdot \rho r \cdot q$ ويظهر من عنزان البحث الأول أنه ليس من بابة موضوعنا، وأما الثاني فهو مقيد بما وقع بين الخلف والسل في فهم لقاء الله، وليس المقصود منه الحصر . 


\section{لقاء الله في القرآن الكريم ( دراسة موضوعية )}

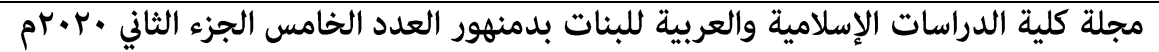

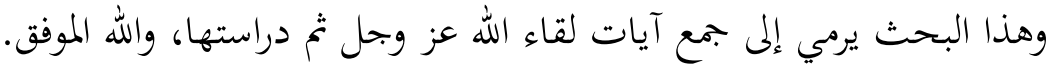
تقسيمات البحث:

وقد اقتضت طبيعة البحث أن يشتمل على مقدمة، وتمهيد، وأربعة مباحث، وخحاتمة.

أما المقدمة: فقد اشتملت على أهمية البحث، وسبب اختيار الموضوع، وأهداف البحث، والمنهج المتبع في الدراسة، والدراسات السابقة، وتقسيمات البحث. التمهيد: التعريف بمصطلحات البحث، وفيه مطلبان: المطلب الأول: مفهوم اللقاء في اللغة. المطلب الثاني: مفهوم اللقاء في الاصطلاحح. المبحث الأول: الإطلاقات اللغوية والمعنوية للقاء الله في القرآن الكريم، وفيه مطلبان: المطلب الأول: الإطلاقات اللفظية. المطلب الثاني: الإطلاقات المعنوية. المبحث الثاني أقسام الناس تجاه لقاء الله تعالى كما جاء في كتاب الله، وفيه

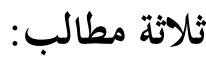
المطلب الأول: إثبات لقاء الله كما عرضها القرآن، وثبت في السنة. المطلب الثاني: المؤمنون بلقاء الله، وعاقبة إيماهم به. المطلب الثالث: المنكرون للقاء الله، وعاقبة إنكارهم له. المبحث الثالث: هل يمكن لقاء الله في الحياة الدنيا؟، وقد اشتمل مطلبين: المطلب الأول: هل يمكن لقاء الله في الحياة الدنيا؟. المطلب الثاني: كلام الله لموسى عليه السلام.(ميقات) المبحث الرابع: مراتب لقاء الله تعالى في الاخرة، وفيه ثلاثة مطالب: المطلب الأول: مراتب لقاء المؤمنين الله في الآخرة. المطلب الثاني: مراتب لقاء الكافرين الله. المطلب الثالث: نتائج لقاء الله تعالى. الخاتمة: فقد اشتملت على أهم النتائج التي توصل إليها البحث. 


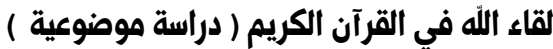

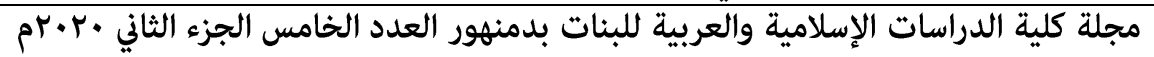

\section{التمهيل}

\section{مفهوم اللقاء وما يلتبس بله \\ المطلب الأول : مفهوم اللقاء في اللغة}

(لاقاه) ملاقاة ولقاء قابله وصادفه والله صار إلى حسابه وفي التنزيل العزيز

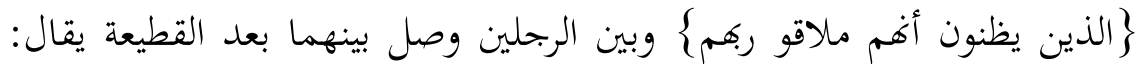
لاقى بين فلان وفلان ويقال لاقى بين طرفي القضيب عطف طرفيه حتى تلاقيا فهو ملاق ويقال هو جاري مالاقي مقابلي:

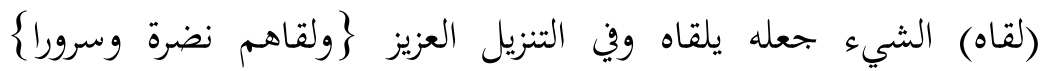

$$
\text { [سورة الإنسان الآية: } 11 \text { ] } 11 \text { ] }
$$

(التقيا) استقبل كل منهما صاحبه؛ يقال: التقى الجمعان والتقى الجيشان والتقى الرجلان والشيئان اجتمعا وتحاذيا وفي التنزيل العزيز \}مرج البحرين يلتقيان

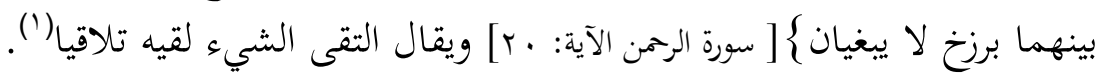
ويقال: لقي فلان فلانا لقاء ولقيا ولقية واحدة، وهي أقبحها على جوازها.

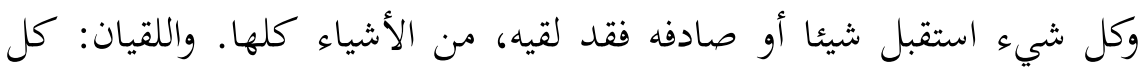
شيئين يلقى أحدها صاحبه، فهما لقيان. وروي عن عائشة أها قالت: (إذا

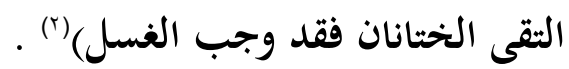
وقال الشافعي: التقاؤهما من المرأة والرجل: تحاذيهما مع غيوب الحشفة في فرجها، لا أن يماس ختانه ختاها، وذلك أن الحشفة إذا غابت في الفرج منها صار

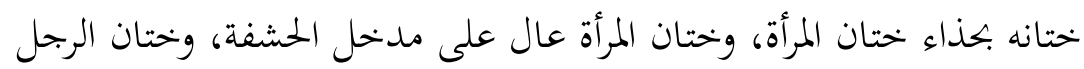
أسفل من ذلك، وهو موضع قطع الفرلة من الذكر. فهذا معنى التقاء الختانين().

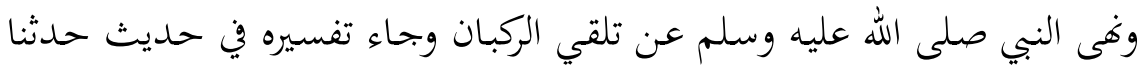
به محمد بن إسحاق عن أبي حاتم الرازي، عن الأنصاري، عن هشام بن حسان، ونسي،

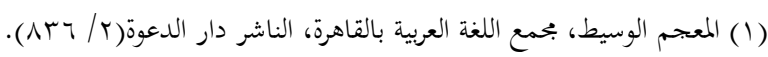

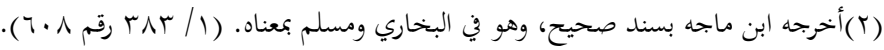

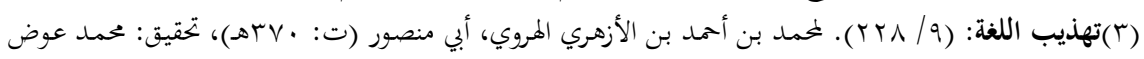

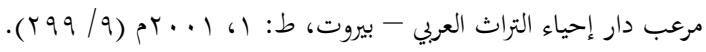




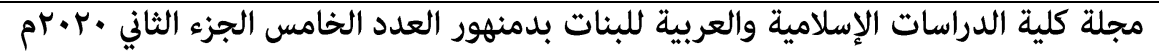

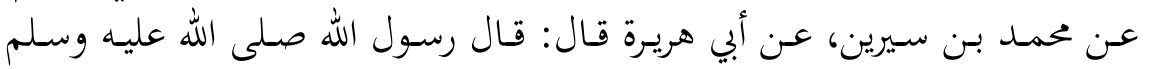
(لا تتلقوا الركبـان والأجحالاب، فمن تلقـاه فاشترى منه شيئا فصـاحبه بالخيـار

إذا أتى السوق) (') وفي الشعر:

وإني لأهوى النوم من غير نعسة ... لعل لقاكم في المنام تكون(r) والأصل الآخر: ألقيته: نبذته إلقاء. والشيء الطريح لقى . والأصل ألى أن قوما من العرب كانوا إذا أتوا البيت للطواف قالوا: لا نطوف في ثياب عصينا الله فيها، فيلقوها، فيسمى ذلك الملقى لقى (r). قال ابن أحمر يصف فرخ القطاة:

تؤوي لقى ألقي في صفصف .... تصهره الشمس فلا ينصهر (£). والتقوا وتلاقوا بمعنى. واستلقى على قفاه. وتلقاه، أي استقبله. وقوله تعالى: (إذ تلقونه بألسنتكم) أي يأخذه بعض عن بعض. وجلس تلقاءه، أي حذاءه.

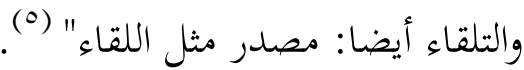

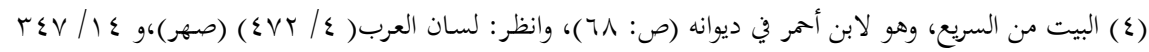

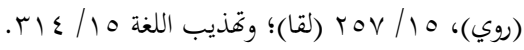

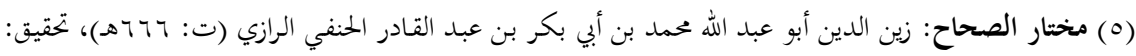

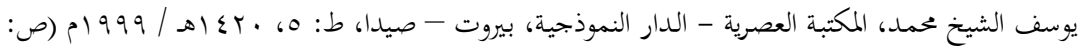




\section{لقاء الله في القرآن الكريم ( دراسة موضوعية )}

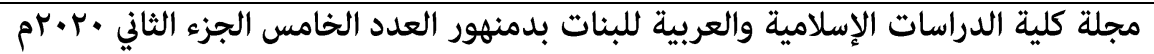

\section{المطلب الثاني : مفهوم اللقاء في الاصطلاح}

قال شيخ الإسلام ابن تيمية: "أما اللقاء، فقد فسره طائفة من السلف والخلف بما يتضمن المعاينة والمشاهدة بعد السلوك والسير وقالوا: إن لقاء الله يتضمن رؤيته سبحانه وتعالى وأطال في ذلك واحتج له، فقال: هو رؤية الله تعالي في الآخرة، وهذا ما اتفق عليه الصحابة وأئمة الإسلام من أن المؤمنين يرون ركهم في الآخرة دل على ذلك العقل والسمع. ولقاء الله قد ذكر في كتاب الله وسنة رسوله في مواضع كثيرة مطلقا غير

مقترن بما يدل على أنه أريد بلقاء الله لقاء بعض مخلوقاته من جزاء أو غيره"( ). واللفظ إذا تكرر ذكره في الكتاب ودار مرة بعد مرة على وجه واحد وكان المراد به غير مفهومه ومقتضاه عند الإطلاق ولم يبين ذلك كان تدليسا وتلبيسا يجب أن يصان كلام الله عنه الذي أخبر أنه شفاء لما في الصدور وهدى ورحمة للمؤمنين وأنه بيان للناس وأخبر أن الرسول قد بلغه البلاغ المبين وأنه بين للناس ما نزل إليهم وأخبر أن عليه بيانه ولا يجوز أن يقال: ما في العقل دلالة على امتناع إرادة هذا المعنى هو القرينة التي دل المخاطبين على الفهم بها(r). وقال ابن القيم: - ماء

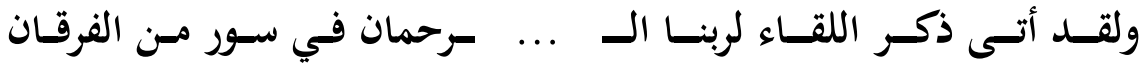

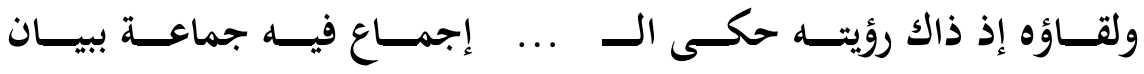

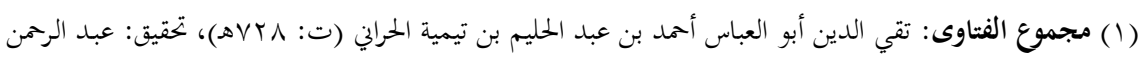

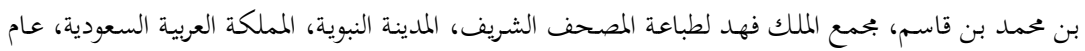

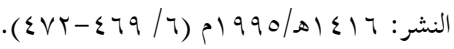

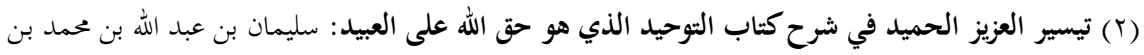

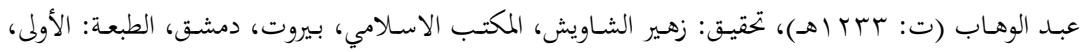

$$
\text { r }
$$




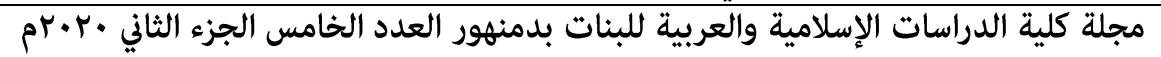

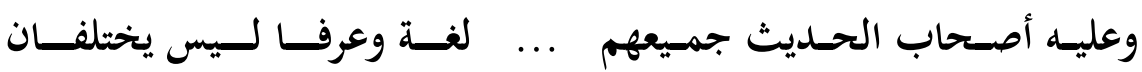

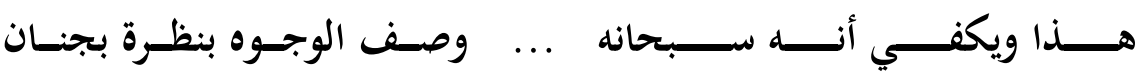

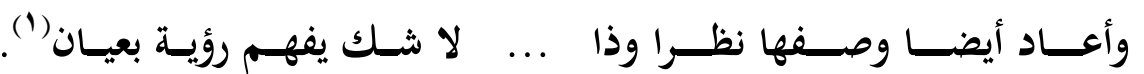
قال الحافظ ابن حجر: اللقاء أعم من الرؤية ويكتمل على بعد أن يكون في قوله لقاء الله حذف تقديره لقاء ثواب الله ونحو ذلك ووجه البعد فيه الإتيان بمقابله لأن أحدا من العقلاء لا يكره لقاء ثواب الله (r).

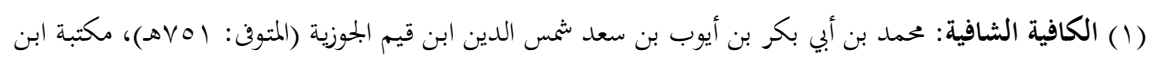

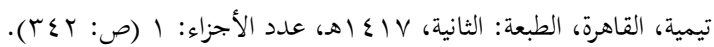

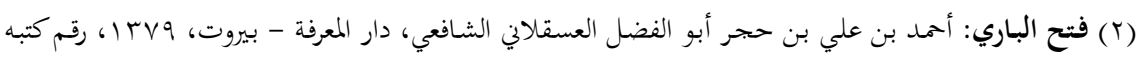

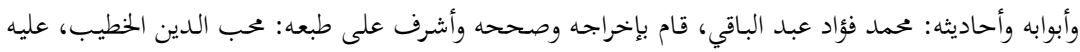

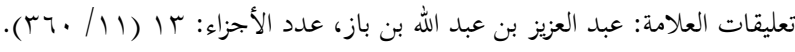




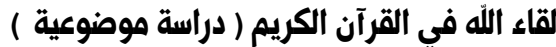

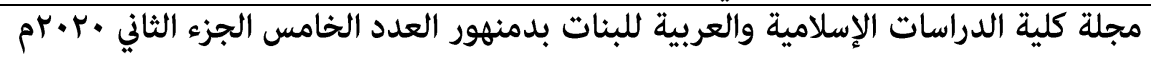
المبحث الأول : الإطلاقات اللفظية والمعنوية للقاء الله في القرآن الكريه، وفيه مطلبسان :

\section{المطلب الأول : الإطلاقة وات اللفظية.}

ورد لفظ لقاء الله تعالى في القرآن الكريم بصيغ مختلفة وباشتقاقات متعددة، وذلك على النحو التالي: أولا : صيغة المصدر، وقد ورد لفظ لقاء الله تعلى على صيغة المصدر وذلك في ستة عشر موضعا:

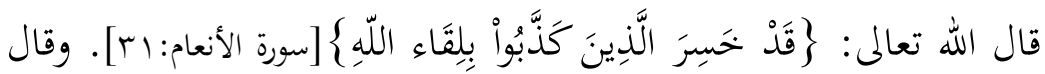

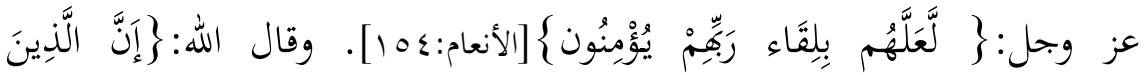

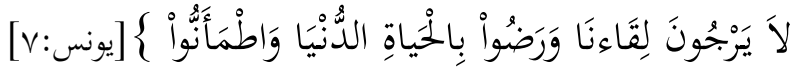

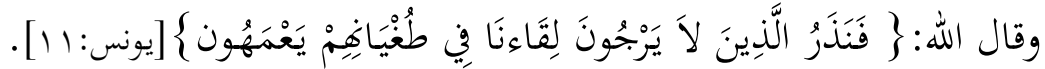

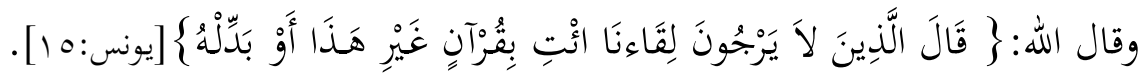

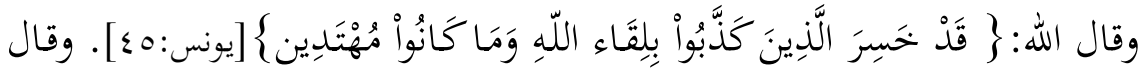

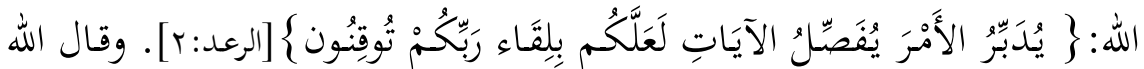

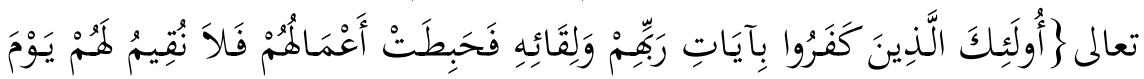

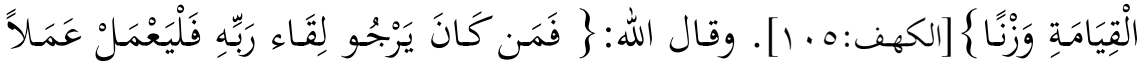

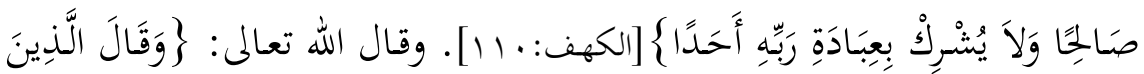

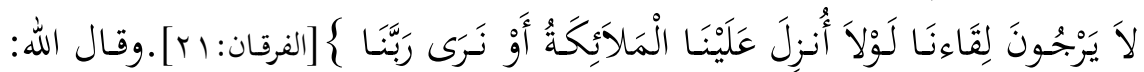

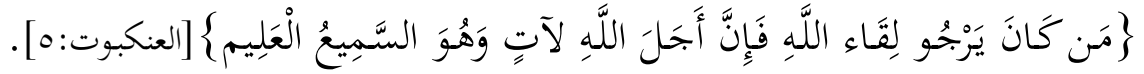

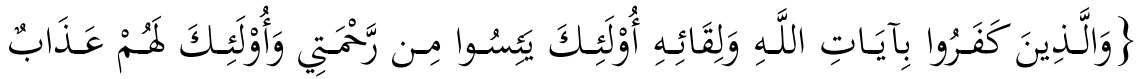

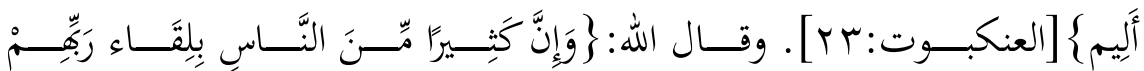
لَكَافِرون

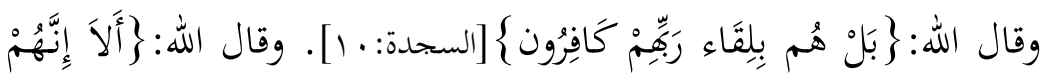

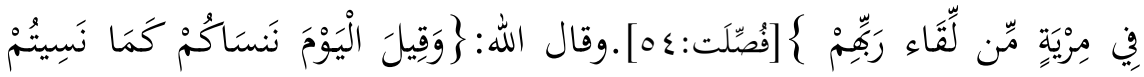

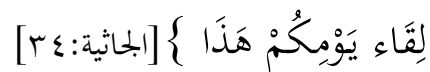




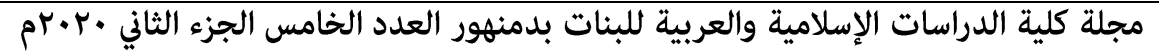

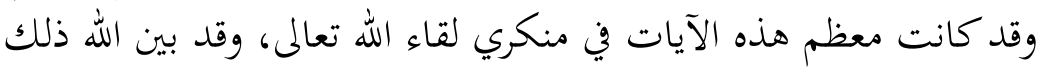
في كتابه مصورا عملهم لمن يتلوا آياته ويطلع على عواقب إنكارهم بلقاء الله تعالى

ففي الموضع الأول من سورة الأنعام، يذكر الله تعالى عن الكفار أهم

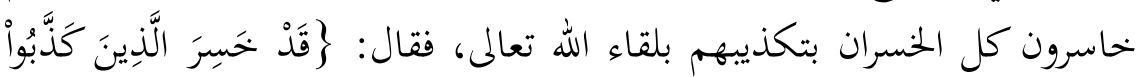
بِلقَاء اللّهِ ، وكذلك الموضوع الثالث من سورة يونس وأما في الموضع الثاني من سورة الأنعام فقد ذكر الله تعالى منته على بني إسرائيل بإنزاله الكتاب على موسى وووصفه بالتمام، وأن فيه تفصيلا لكل شيء؛ قال الله تعالى: $\}$

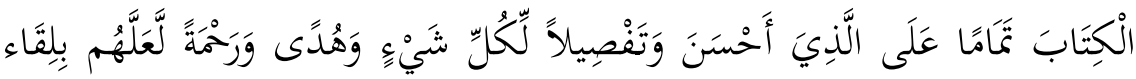

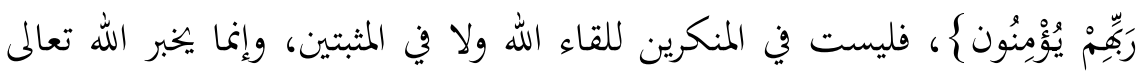
أنه أنزل إليهم هذا الكتاب التام الذي فصّل فيه كل شيء محا يهديهم ويرشدهم إلى الإيمان بلقاء الله تعالى.

ووفي موضع الأعراف ذكر الله تعالى -على سبيل المشاكلة- أنه ينساهم يوم القيامة نتيجة نسياهم للقاء الله تعالى، وجحدهم بآياته، فقال:

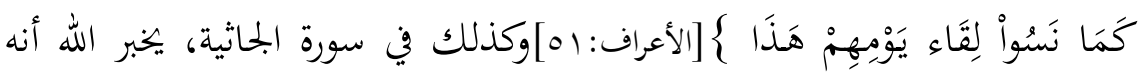
نسيهم كما نسوا لقاء ربهم.

ويف الموضع الأول من يونس ذكر الله تعالى أنه يترك الكفار الذي لا يرجون

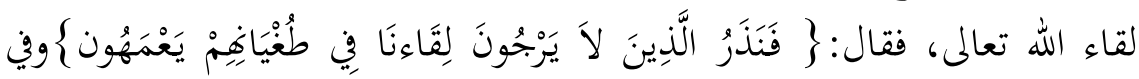
الموضع الثاني من يونس ذكر الله تعالى مطالبة الكفار وتعنتهم محن لا يرجون لقاء

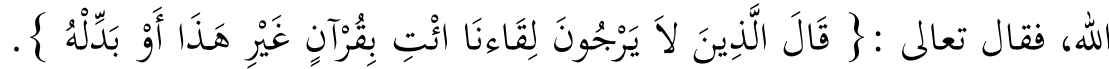
ووي سورة الرعد يذكر الله تعالى أنه يدبر أمر الناس كلها، ويفصِّل لهم الآيات الدالة على وجوده وقدرته؛ لعلهم يهتدون ويرعون ويوقنون بلقاء الله تعالى،

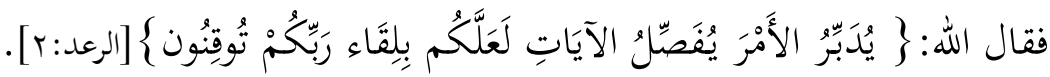

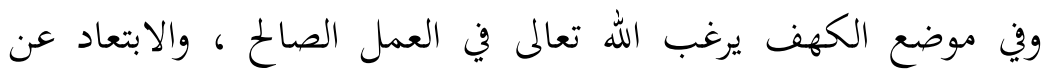
الشرك إذا كانوا يرجون لقاء الله تعالى يختلف عما سبق فهو لقاء خاص لمن عمل 


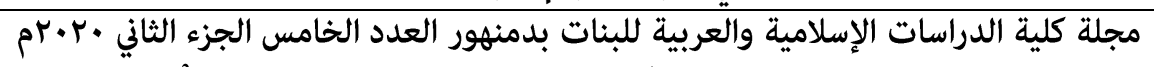

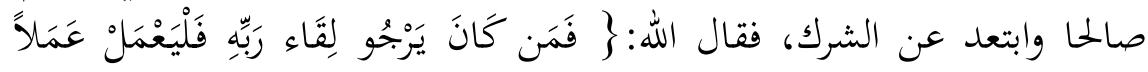

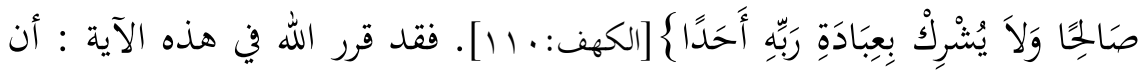
على الذين يرجون لقاء الله وما عنده من الحسنى أن يؤمنوا به ويعملوا صالح الأعمال ولا يشركوا به أحدا.

قال البغوي: من كان يرجوا لقاء الله، قال ابن عباس رضي الله تعالى احلى عنهما، ومقاتل: من كان يخشى البعث والحساب، والرجاء بمعنى الخوف، وقال سعيد بن جبير رضي الله عنه: من كان يطمع في ثواب الله، فإن أجل الله لآته، معات يعني ما وعد الله من الثواب والعقاب. وقال مقاتل: يعني يوم القيامة لكائن.

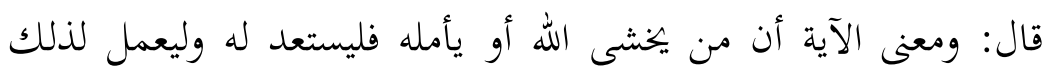

ويف موضع الفرقان: يخبر الله تعالى عن الذين لا يرجون لقاء الله أفم طلبوا

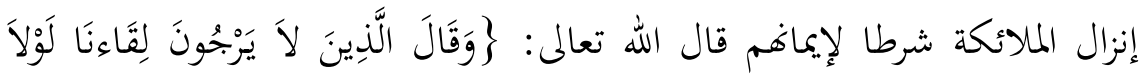

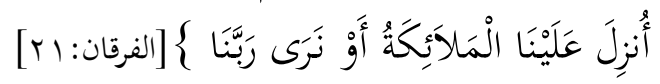
ووفي موضع الروم : يخبر الله تعالى أن كثيرا من الناس يكفرون بلقاء الله،

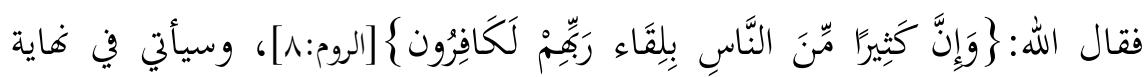
هذا التعليق ذكر أقوال العلماء في معنى لقاء الله، وسبق بعضها في التعليق على آية الكهن.

وفي سورة السجدة ذكر الله الشك الحاصل من الكفار في البعث ، فذكر

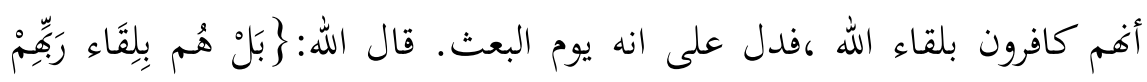
كَافِرون

وفي موضع فصلت يقول الله تعالى مخبرا عن المشككين في الآخر أهم في رون مرية أي شكك من لقاء ربهم، فقال تعالى:

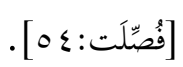




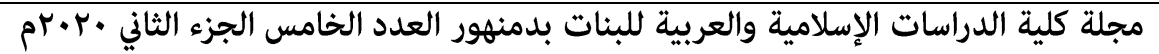

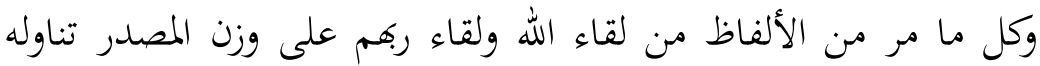
المفسرون بالشرح والبيان، وقد سبق في موضع الكهف نقل البغوي عن ابن عباس رضي الله تعالى عنهما، ومقاتل: أهما فسرا ذلك بالبعث والحساب، وفسره سعيد بن جبير رضي الله عنه: بثواب الله.

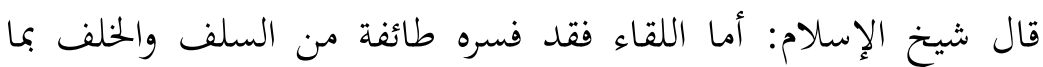
يتضمن المعاينة والمشاهدة بعد السلوك والسير وقالوا: إن لقاء الله يتضمن رؤيته سبحانه وتعالى، وأطال في ذلك واحتج له، وقال سعيد بن جبير: فمن كان يرجو لقاء ربه؛ قال: من كان يخشى البعث في الآخرة ... فليعمل عملا صالحا ولا يشرك بعبادة ربه أحدا أي كائنا ما كان (') ثانيا: صسيغة المصدر الميمي ورد لفظ لقاء الله بصيغة المصدر الميمي في القرآن الكريم في ست مواضع، وهي:

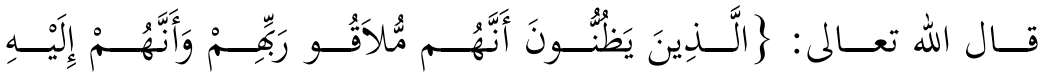

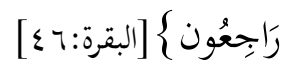

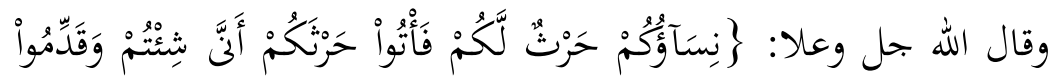

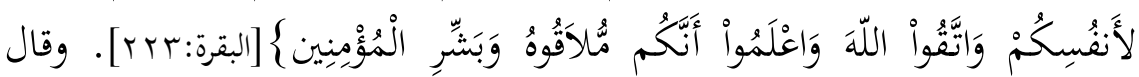
تعالى:

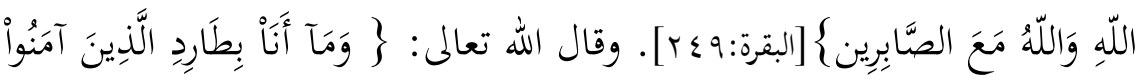

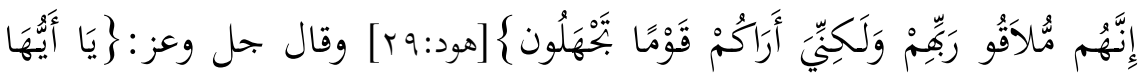

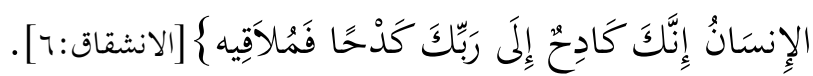
ففي الموضع الأول من سورة البقرة، ذكر الله عن أهل الجنة أهم يتيقنون

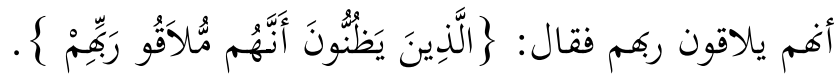




\section{لقاء الله في القرآن الكريم ( دراسة موضوعية )}

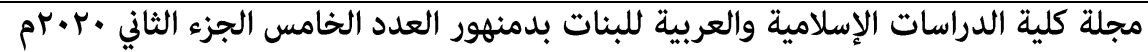

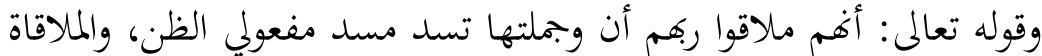
هي للعقاب أو الثواب، ففي الكالام حذف مضاف، ويصح أن تكون الملاقاة هنا بالرؤية التي عليها أهل السنة، وورد بها متواتر الحلديث. قال: ومالاقوا أصله ملاقون، لأنه بمعنى الاستقبال فحذفت النون تخفيفا، فلمـا حـففت تمكنـت الإضـافة لمناسبتها للأسمـاء، وهـي إضـافة غـير محضـة، لأكها لا تعرف (1)

ويي الموضع الثاني من سورة البقرة، يحث الله جل وعلا عباده على تقواه وأنه إليه ملاقوه، فقال الله جل وعلا: $\}$ معاينوه بعد الموت فيجزيكم بأعمالكم (؟). وفي الموضع الثالث من البقرة، ذكر الله عن الفئة المؤمنة مع طالوت حينا

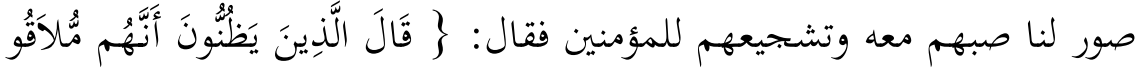

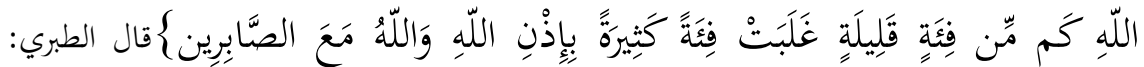

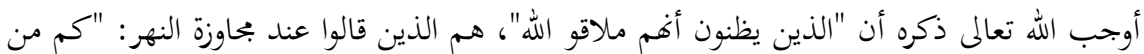

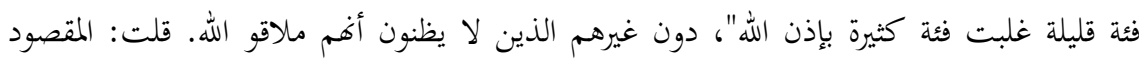

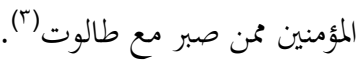
وفي موضع هود يقول الله تعالى عن نوح أنه يأبى أنيطرد المؤمنين؛ لأهم

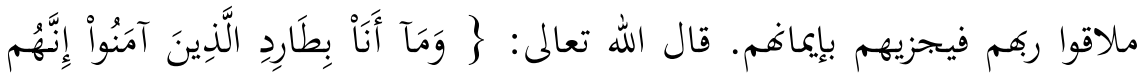

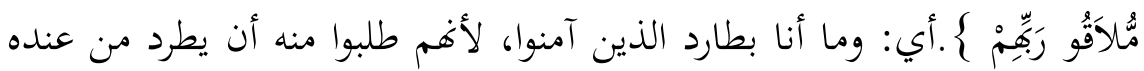
من الفقراء والضعفاء، فقال إهم ملاقوا ربهم فيجزيهم بأعمالهم. ويقال إهم ملاقوا ربهم فيشكوني إلى الله تعالى أن لم أقبل منهم الإيمان وأطردهم، ولكني أراكم قوما تجهلون ما أمرتكم به وما جئتكم به (ء). 


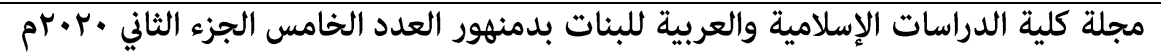

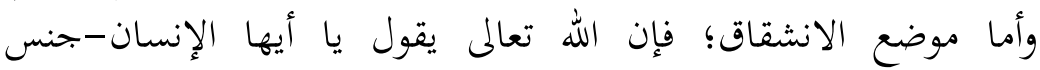
الإنسان- إنك قادم على الله تعالى بعملك فملاقي الله تعالى بعملك او فملاقيه أي مالاق عملك. قال الطبري: يا أيها الإنسان إنك عامل إلى ربك عملا فملاقيه به: خيرا كان عملك ذلك أو شرا؛ يقول: فليكن عملك مما ينجيك من سخطه، ويوجب لك رضاه، ولا يكن محا يسخطه عليك فتهلك('). قال البغوي: أي ساع إليه في عملك، والكدح: عمل الإنسان وجهده في الأمر من الخير والشر حتى يكدح ذلك فيه، أي يؤثر. وقال قتادة والكلبي والضحاك: عامل لربك عملا فملاقيه \{ أي ملاقي جزاء عملك خيرا كان أو شرا(r).

قال ابن عطية: اختلفوا في جواب إذا، فقال كثير من النحاة: هو محذوف ائ لعلم السامع به، وقال أبو العباس المبرد والأخفش: هو في قوله: يا أيها الإنسان إنك كادح إلى ربك كدحا فملاقيه، إذا انشقت السماء، انشقت فأنت ملاقي الله، وقيل التقدير فيا أيها الإنسان، وجواب إذا في الفاء المقدرة، وقال الفراء عن بعض النحاة: هو أذنت على زيادة تقدير الواو، قال: وأما الضمير فملاقيه، فقال جمهور المتأولين هو عائد على الرب، فالفاء على هذا عاطفة مالاق على كادح(؟). ثالثا: بصيغة المضارع ورد لفــ لقـاء الله تعـالى بصـيغة المضـارع في القـرآن الكــيم وذلــك في

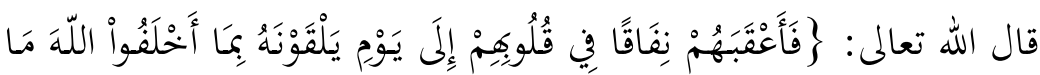

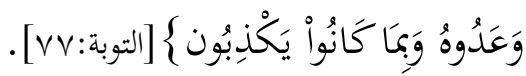
وقـال جـــل وعــال: $\}$

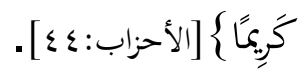




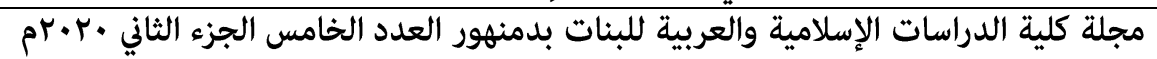

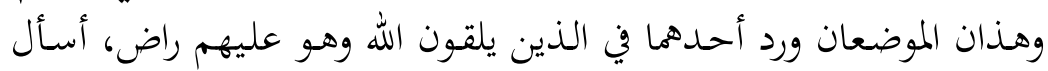

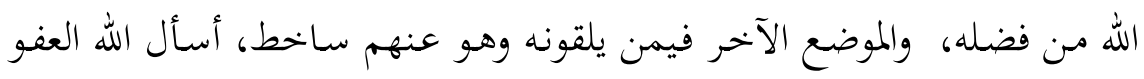
والعافية.

ففي موضع التوبة: يقول أبو جعفر الطبري: يقول تعالى ذكره: ومن هؤلاء

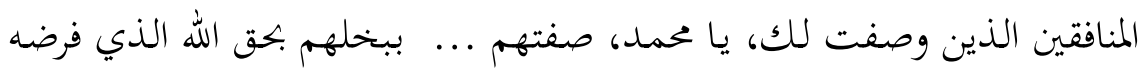

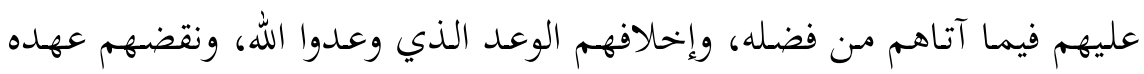
في قلوبهم... مـن الصـدقة والنفقـة في سبيله = (وبما كانوا يكذبون) ، في قيلهم، وحرمهم التوبة منه، لأنه جل ثناؤه اشترط في نفاقهم أنه أعقبهموه إلى يوم يلقونه، وذلك يوم محاتم وخروجهم من الدنيا. قال ابن زيد: هؤلاء صنف من المنافقين، فلما آتاهم ذلك بخلوا بـه، فلما بخلوا بـلك أعقبهم بذلك نفاقا إلى يوم يلقونه، ليس لهم منه توبـة ولا مغفرة ولا عفو، كما أصاب إبليس حين منعه التوبة('). وأمـا آية الزمر فقد ذكر الله ما أعده للمتقـين من النعيم، فقـال جل ثناؤه: تحية هؤلاء المؤمنين يوم القيامة في الجنة سلام، يقول بعضهم لبعض: أمنة لنا ولكم

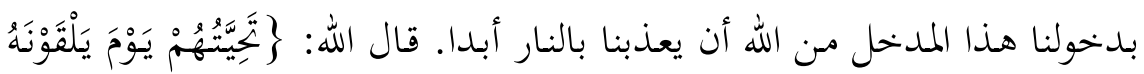

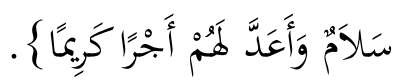

وبهذا تنتهي الإطلاقات اللفظية للقاء الله تعالى الواردة في القرآن الكريم ما جاء منها على صيغة المصدر، وما جاء منها على صيغة المصدر الميمي، وما جاء

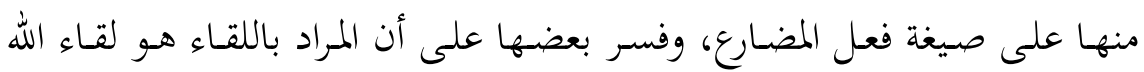
أي: معاينته، فاستلزم ذلك عندهم رؤيته سبحانه، وفسر بعضه على لقاء الثواب أو العقاب، في الآخرة. 


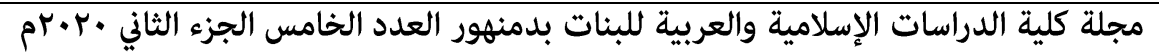

\section{المطلب الثاذي : الإطلاقات المعنوبة واتية}

سبق في المطلب الأول ذكر صيغ الألفاظ التي ورد فيها لفظ لقاء الله بلفظ اللقاء أو ما تصرف منه، وفي هذا المطلب نذكر الألفاظ الدالة على لقاء الله تعالى بالمعنى وليس باللفظ، فأورد الآية فتفسر عند جمهور المفسرين على أن المراد منها

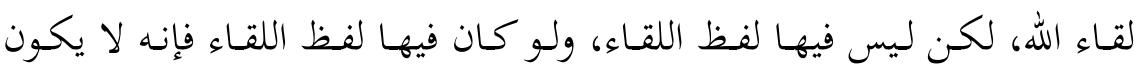
راجعا إلى الله تعالى ، وإنما يكون راجعا إلى العمل، أو إلى اليوم الآخر ونهوه. ومن هذه الآيات: قوله تعالى: [الأعراف:010] يعني: يوم القيامة.

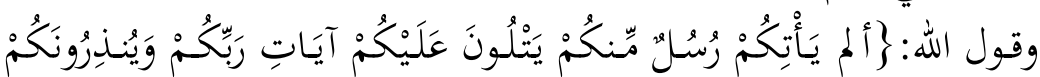

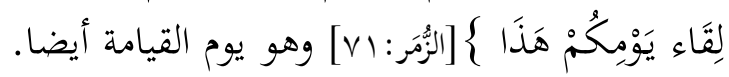

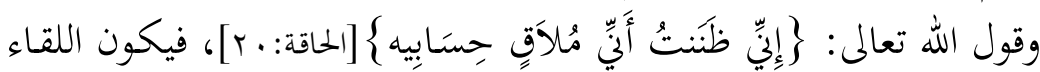

$$
\text { هنا راجعا إلى الحساب. }
$$

وقد ورد في هـا المعنى وهـو لقـاء الله تعالى آيات كثيرة مـن غـير مـا سبق.

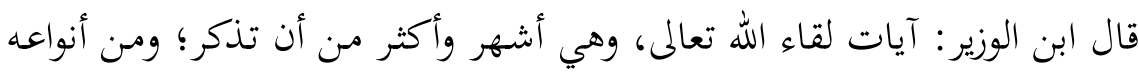

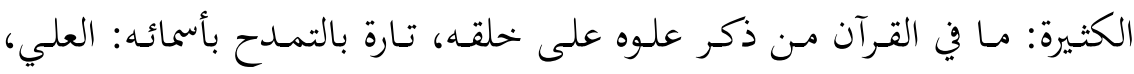

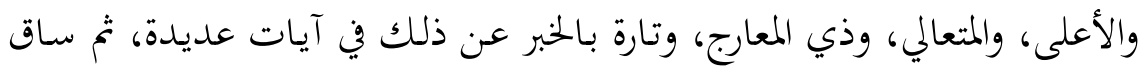

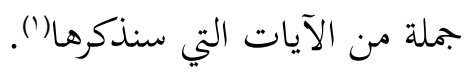

وسوف أسـرد جملة مس تلك الآيـات ثم انتخـب منهـا جملة أخرى للشـرح

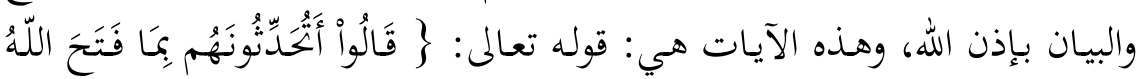

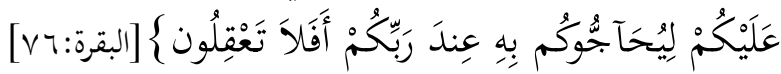

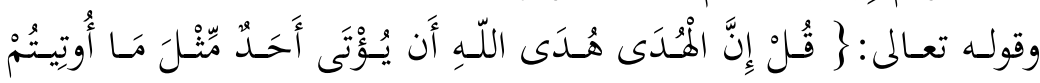

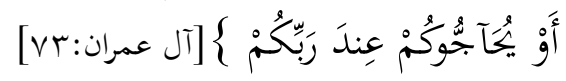

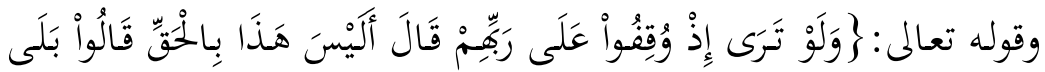

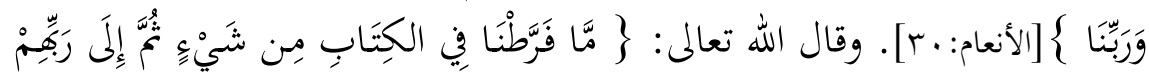




\section{لقاء الله في القرآن الكريم ( دراسة موضوعية )}

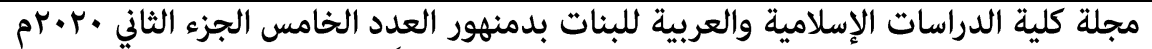

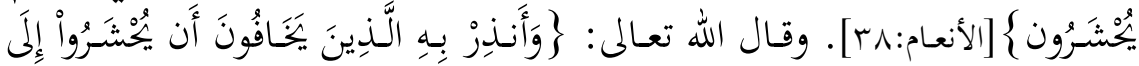

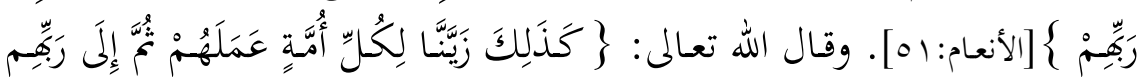

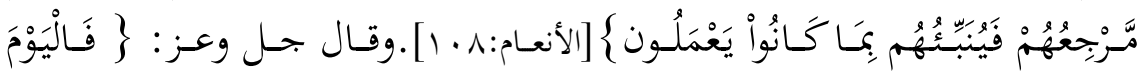

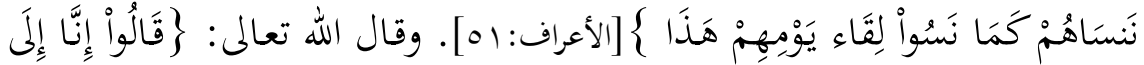

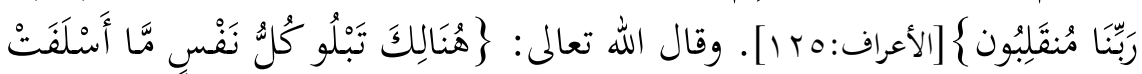

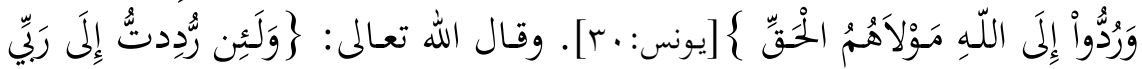

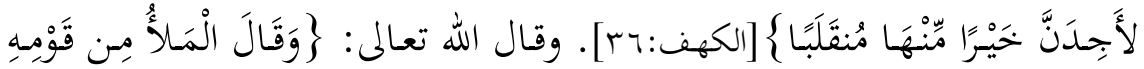

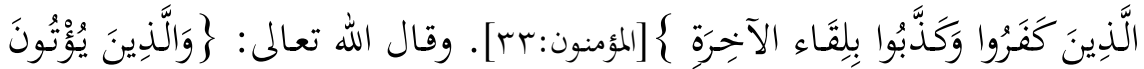

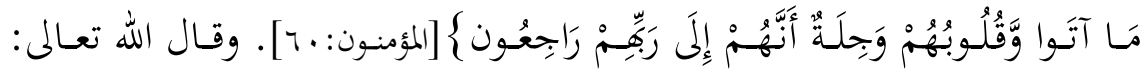

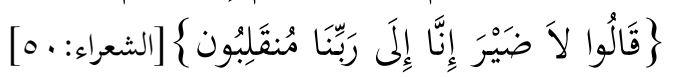

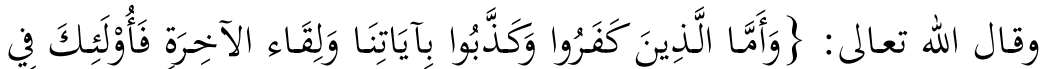

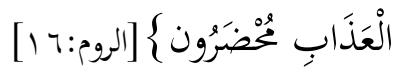

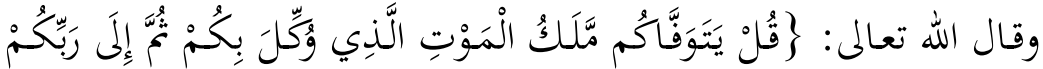

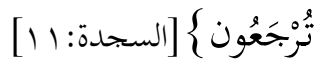

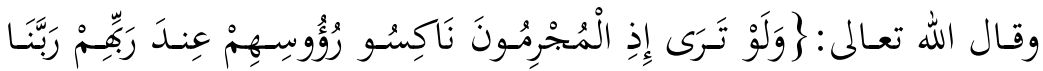

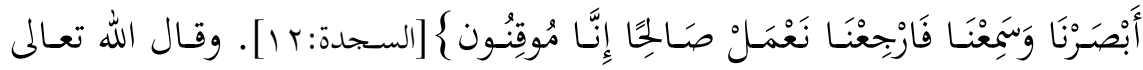

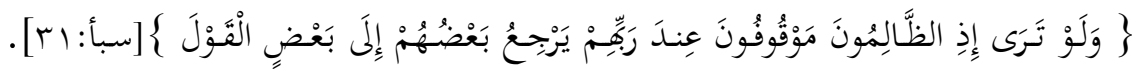

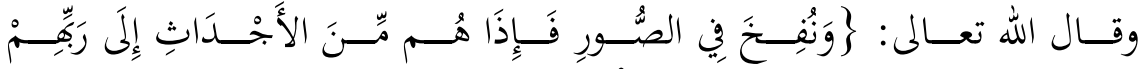

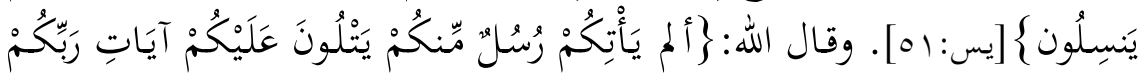

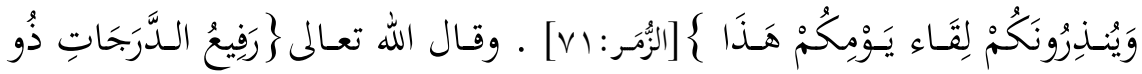

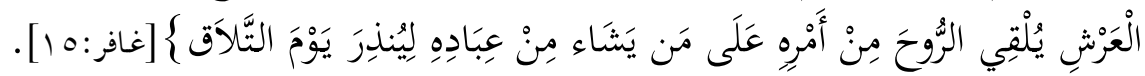

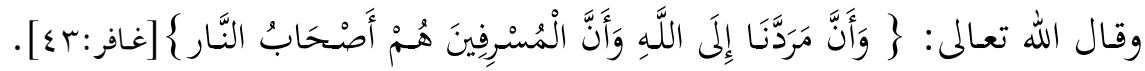

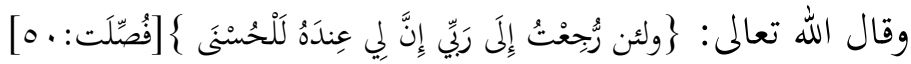
وقال الله تعالى:

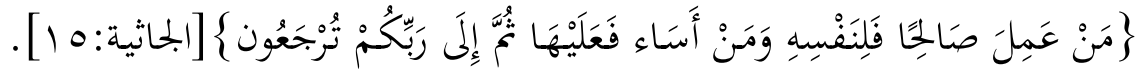
وقال الله تعالى:

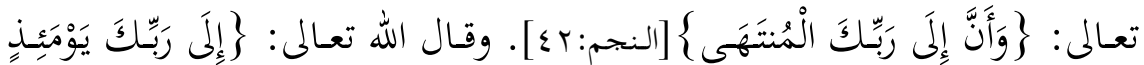




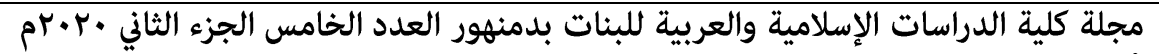

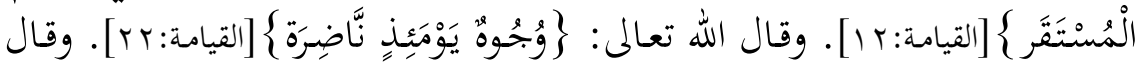
الله تعـالى: $\}$

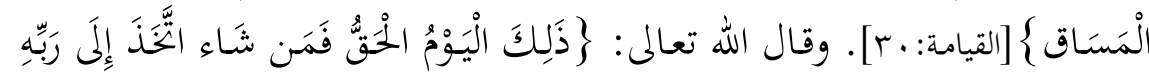
مَآبًا $[$ النبأ:وبr]. وقال الله تعالى: $\}$ وقد أنتخبت من جميع ما سبق أربع آيات تكون أكثر دلالة على لقاء لقاء الله عز وجل فأذكر فيها ما يسر الله لي من أقوال العلماء في تفسيرها.

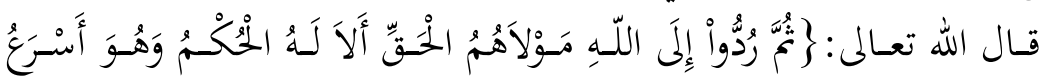

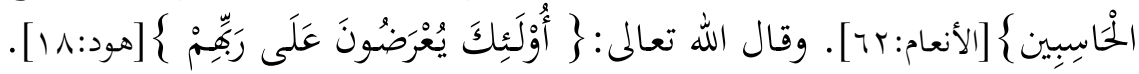

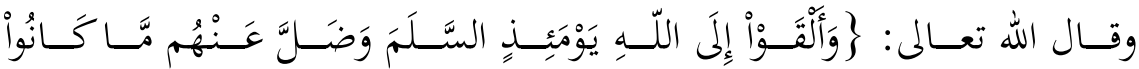

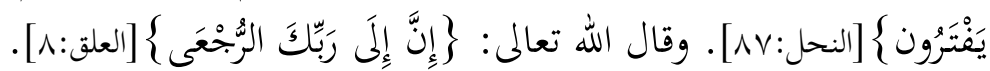

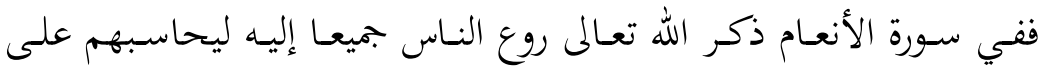

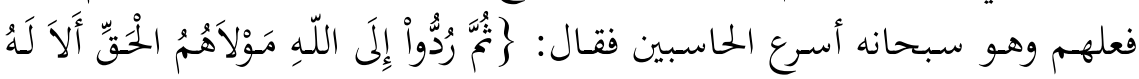

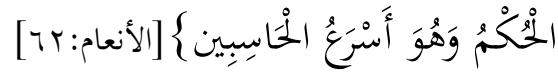
قال أبو جعفر: يقول تعالى ذكره: ثم ردت الملائكة الذين توفوهم فقبضوا نفوسـهم وأرواحهـم، إلى الله سـيدهم الحـق، ... وهـو أسـرع مـن حسـب عـددكم

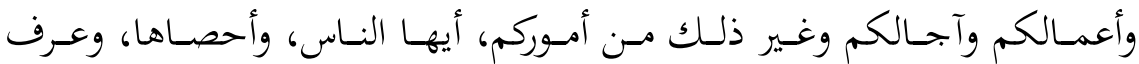

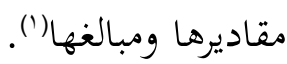

وقـال البغـوي: ثم ردوا إلى الله مـولاهم الحـق، يعني: الملائكسة، وقيـل: يعني

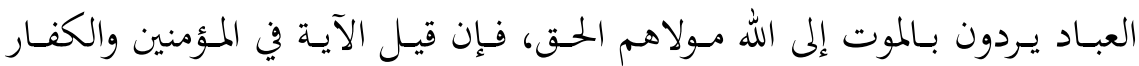

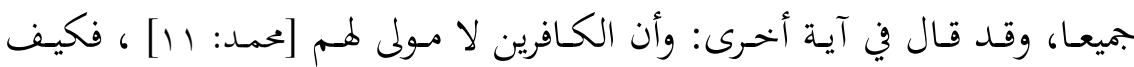

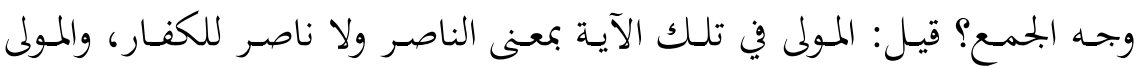
هاهنا بمعنى المالك الذي يتولى أمورهم، والله عز وجل مالك فيك الكل ومتولي الأمور.

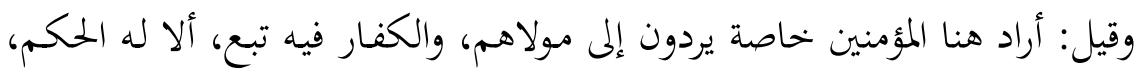




\section{لقاء الله في القرآن الكريم ( دراسة موضوعية )}

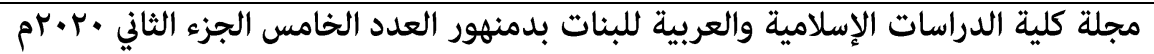

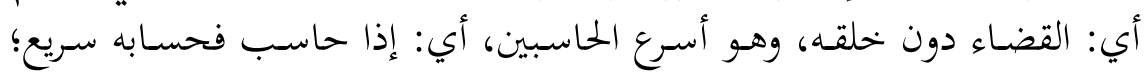
لأنه لا يحتاج إلى فكرة وروية وعقد يد (').

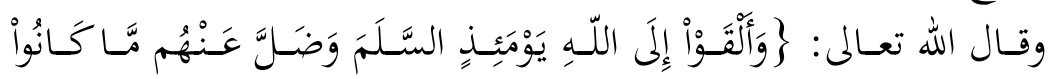

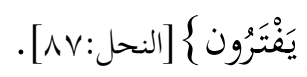

وفي سـورة هـود ذكر الله تعـالى أن عبـاده سيعرضـون عليـه، فقـال تعـالى:

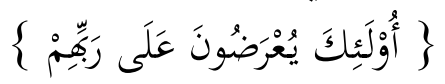

قال أبو الليـث السمرقندي: أولئك يعرضون على على ركهم يعني: يساقون إلى

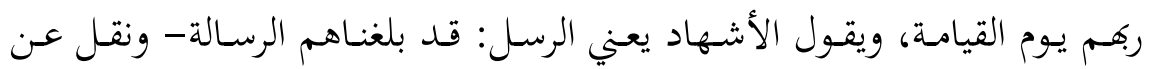
الضحاك أنه قال: ويقول الأشهاد، يعني: الأنبياء(r).

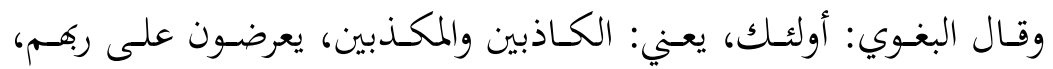

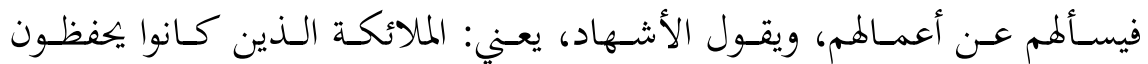

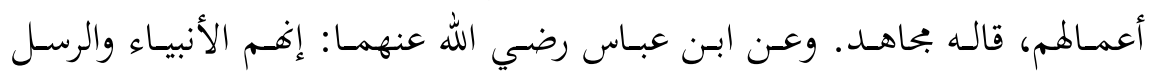
عليهم الصلاة والسلام، وهو قول الضحاك. وقال قتادة: الخلائق كلهمب(ّ). وقد روى البخـاري، ومسـلم، وابن أبي حساتم وغيرهم عن صفوان بـن محرز

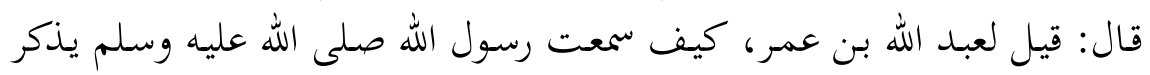

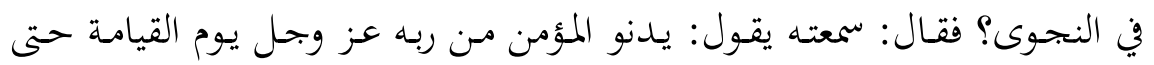
يضع عليه كنفه ثم يقرئه بذنوبه هل تعرف؟ فيقول: يا رب أعرف حتى إذا بلغ منه

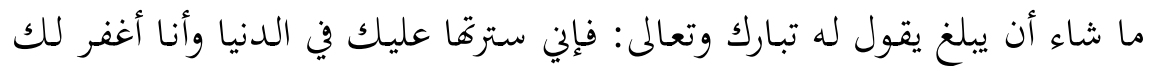
اليـوم قـال تم يعطى صسحيفة حسـابه أو قـال: كتابـه بيمينـه وأمـا الكـافر والمنـافق

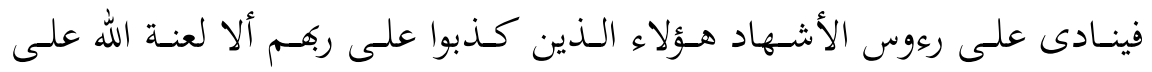

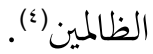

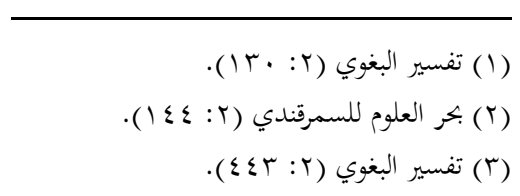

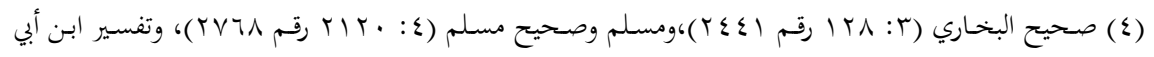

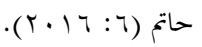




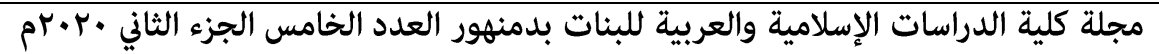

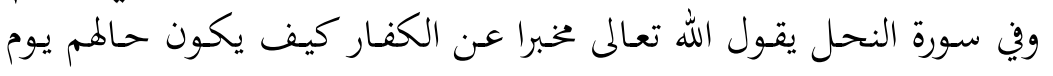

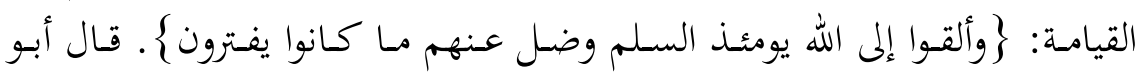
جعفر الطبري: يقـول تعـالى ذكره: وألقى المشـركون إلى الله يومئذ السـلم يقـول:

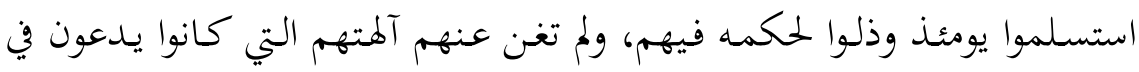
الدنيا من دون الله، وتبرأت منهم، ولا قومهم، ولا عشائرهم الذين كانوا في الدنيا

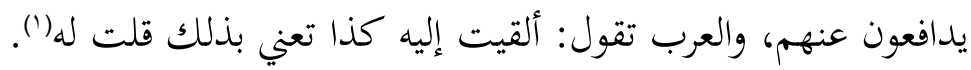
قال أبو الليث السمرقندي: قوله عز وجل: وألقوا إلى الله يومئذ السلم أي:

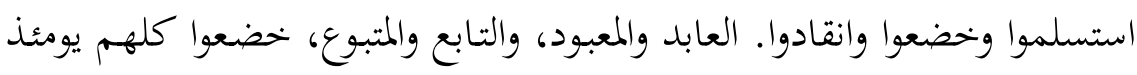

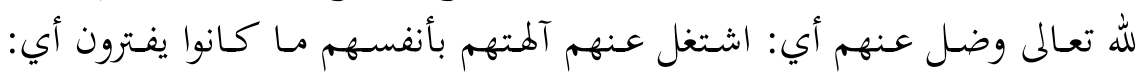

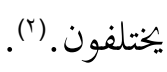

ونقـل ابـن كثير عـن قتـادة وعكرمـة قـالا: : ذلـوا واستسـلموا يومئـذ، أي

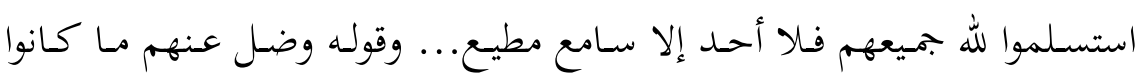

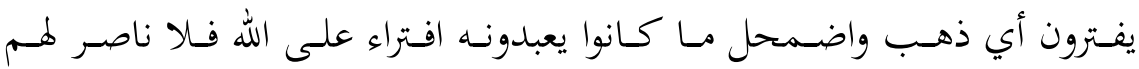

$$
\text { ولا معين ولا بحير (َ). }
$$

وفي سـورة العلق يخـبر الله عـز وجـل بـأن النـاس كلهـم راجعـون إلى الله عـز

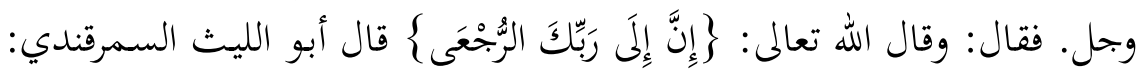

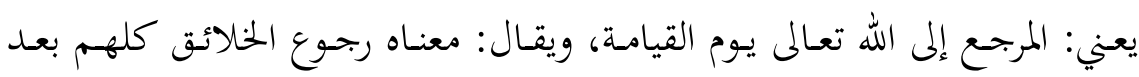

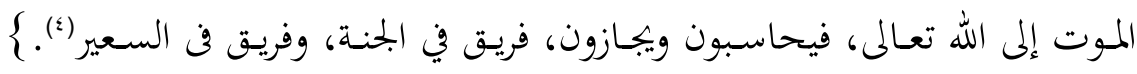

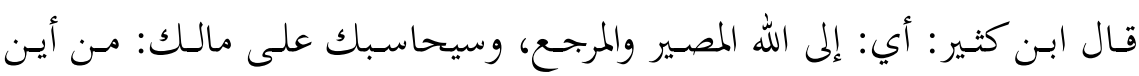
جمعته؟ وفيم صرفته؟(ن).

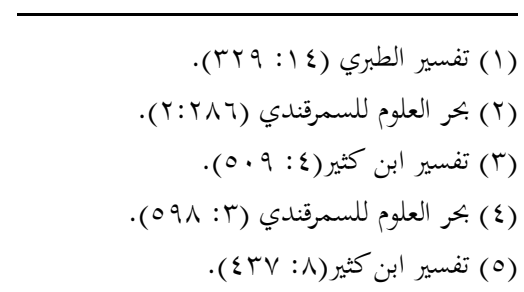


لقاء اللآه في القرآن الكريم ( دراسة موضوعية )

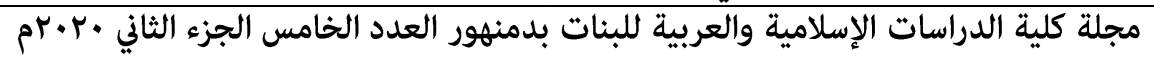
المبحث الثاني أقسام الناس تجاه لقاء الله تعالى كما جاء في كتاب اللهابه ،

وفيه ثلاثة مطالب :

\section{المطلب الأول : إثبات لقاء الله كما عرضه القرآذ، وثبت في السنة.}

سبق في المبحـث السـابق سـرد الآيـات التي ورد فيها لقـاء الله في أكثر مـن عشرين آية بين الاستعمالات اللفظية، وأكثر من عشرين أخرى في الاستعمالات المعنويـة، وسأقتصـر هنـا في ذكر بعض الآيـات التي فيها لقـاء الله لفظا؛ قـال الله

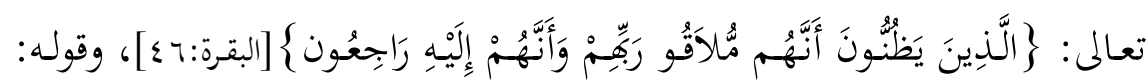

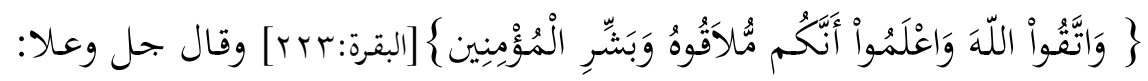

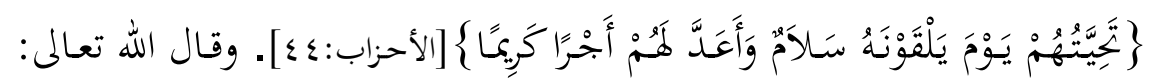

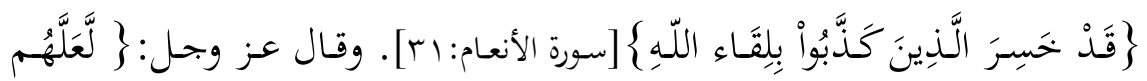

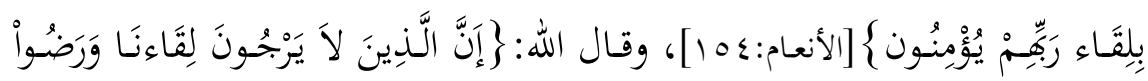

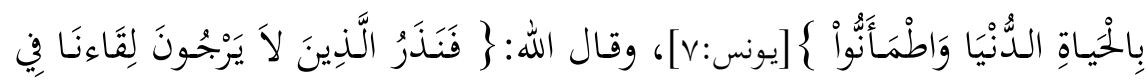

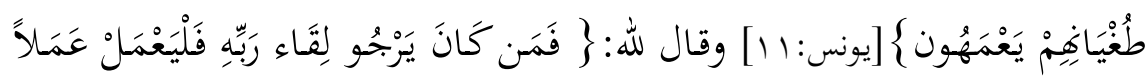
صَالحِاًا وَلاً يُشْرِكْ بِعبَادَة رَبِّهِ أَحَدًا

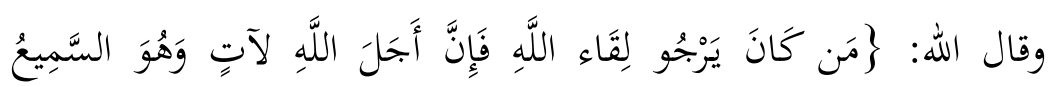
الْعَلِيم [العنكبوت:0]، وآيات كثيرة أتركها خشية التطويل والإعادة، وقد سردها كلها الرازي في حجج القرآن(') حجج القرآن. وقد سبق شرح بعض تلك الآيات في الاستعمالات اللفظية. وقد جاء ذلك في السنة أيضا. فاللقاء ثابت بنص القرآن كما تقدم، وبالتواتر عن النبي - صلى الله عليه وسلم -، وكل أحاديث اللقاء صحيحة؛ منها: حديث أنس بن مالك رضي الله 


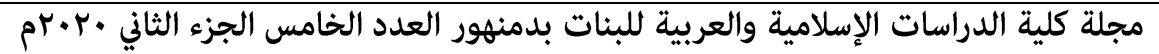
عنـه في قصسة بئـر معونـة: وفيـه....(أنـا قـد لقينـا ربنـا، فرضسي عنسا وأرضـانا) ('). وحديث عبـادة وعائشة وأبي هريرة رضي الله عنهم: (من أحب لقاء الله، أحب الله لقـاءه)(r). وحـديث أنس بـن مالكك رضـي الله تعـالى عنـه: (إنكـم سـتلقون بعدي أثرة، فاصبروا حتى تلقوا الله ورسوله)(") وحـديث أبي ذر رضي الله عنـه: (للو لقيتنسي بقـراب الأرض خطايسا، ثـم

لقيتني لا تشرك به شيئا لقيتك بقرابها مغفرة)(๕). وحـديث أبي موسى الأشعري رضي الله عنه: ( مـن لقي الله لا يشـرك بـه شيئا دخل الجنة)(•)

وغسير ذلـك مـن أحاديـث اللقــاء الـتي وردت في الســة النبويسة، وكلهــا صحيحة، والسنة إنما هي شاحة لكتاب الله تعالى، والسنة وحي؛ فبان النبي صلى الله عليه وسلم قال: (ألا إني أوتيت الكتاب، ومثله معه ألا يوشك رجل شبعان على أريكته يقول عليكم بهذا القرآن فما وجـدتم فيه من حالال فأحلوه، وما وجدتم فيه من حرام فحرموه... الحديث)(").

وبهـذا يـتم مـا قصـــت إيـراده في هـذا البـاب مـن إثبـات لقــاء الله تعـالى بالكتاب والسنة، والله تعالى أعلم.

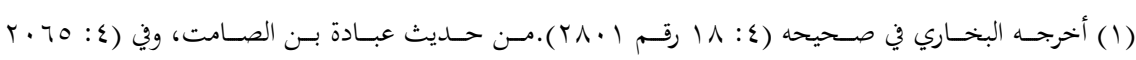

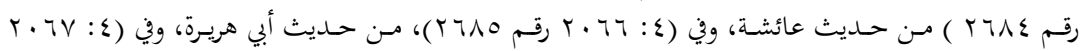

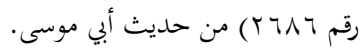

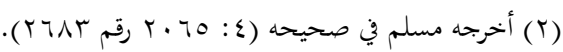

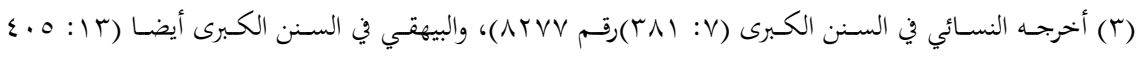

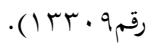

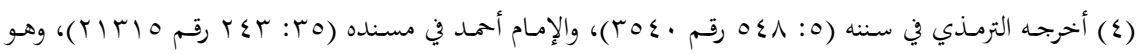
حديث صحيح.

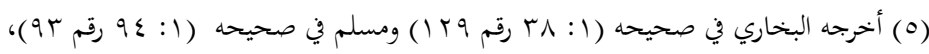

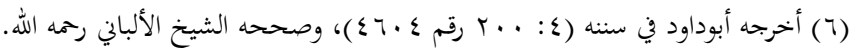




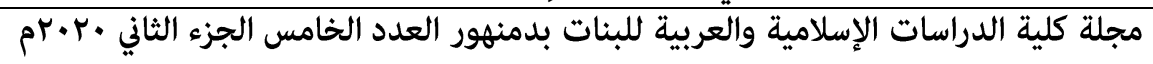

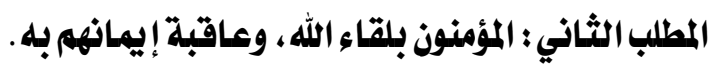

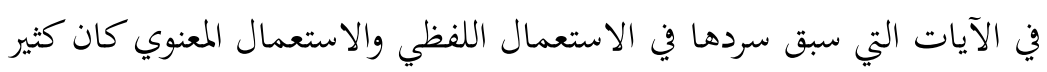
منها فيمن أنكر لقاء الله تعالى، وكان بعضها أيضا فيمن يؤمن بلقاء الله تعالى، ولعلي أذكر في هذا المبحث الآيات التي ذكر فيها المؤمنون بلقاء الله تعالى، ومن ذلك: قـال الله تعـالى: $\}$

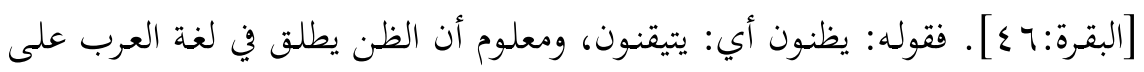

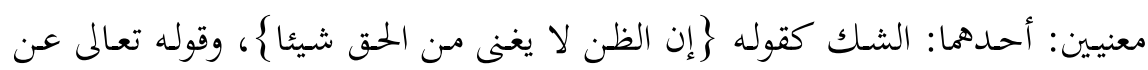
الكفار : $\}$

والثاني: هو إطلاق الظن مرادا به العلم واليقين، ومثل هذه الآية: قوله تعالى:

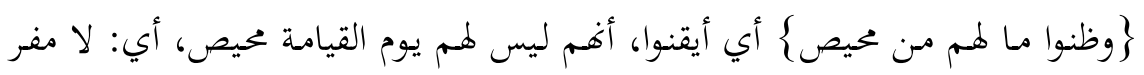
ولا مهرب لهم من عذاب ربهم، ومنه بهذا المعنى قوله تعالى: كورأى البحرمون النار فظنوا

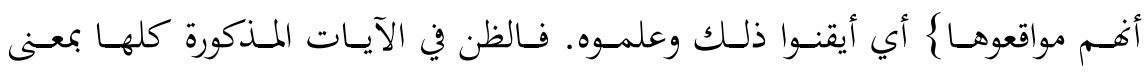

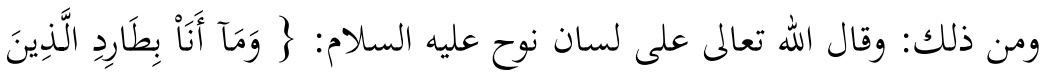

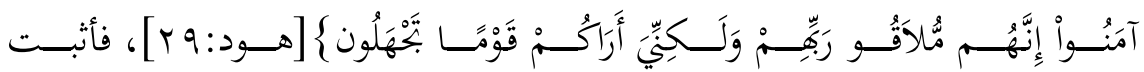
بمـا لا بحـال للشـك فيسه أهـم ملاقـوا ربهـم، وقـد سـبق شـرح هـذه الآيـة في الاستعمال

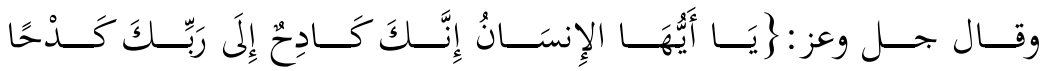

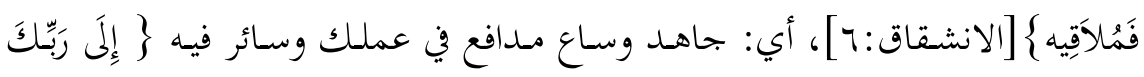

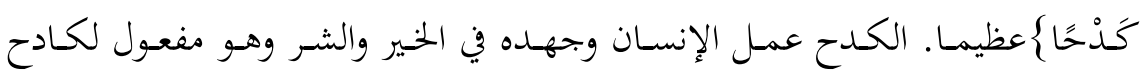

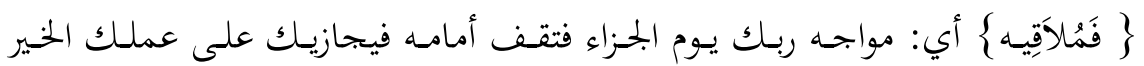

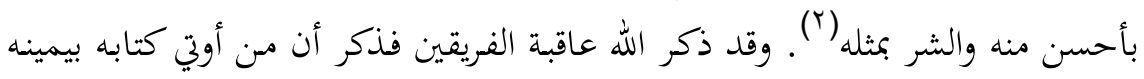
فإن يحاسب حسابا يسيرا. 


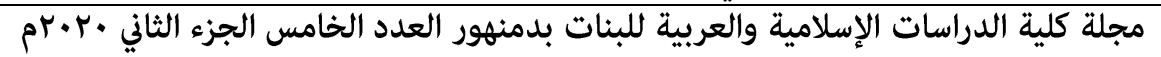

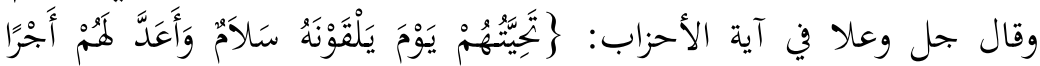
كَيمًا [الأحزاب: ؟ــ].فذكر الله تعالى عاقبة المتقين الذين يؤمنون بلقاء الله تعالى أن تحيتهم وتحية الملائكة لمم وتحية بعضهم بعضا يوم يلقونه سلام.

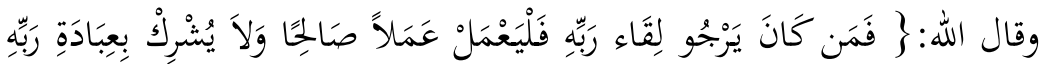

$$
\text { أَحَدًا }
$$

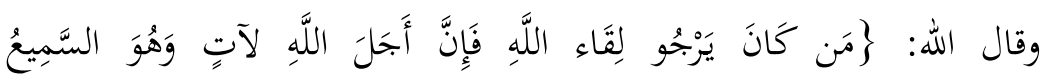

$$
\text { الْعَلِيم \{ [العنكبوت: }
$$

قال الطاهر بن عاشور رحمه الله تعالى: هذا مسوق للمؤمنين خاصة لأهم الذين

$$
\text { يرجون لقاء الله (') }
$$

قال القشيري: حمل الرجاء فن هذه الآية على خوف العقوبة ورجاء المثوبة حسن، ولكنّ ترك هذا على ظاهره أولى فالمؤمنون قاطبة يرجون لقاء الله.

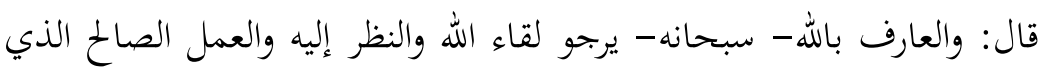
بوجوده يصل إلى لقائه هو صبره على لواعج اشتياقه، وأن يخلص في عمله (r). والتعبير بالمضارع فن (يَرْجُوا) للدلالة على أن اللائق بحال المؤمنين: الاستمرار والاستدامة على رجاء اللقاء، أي: فمن استمر على رجاء لقاء كرامة الله ورضوانه

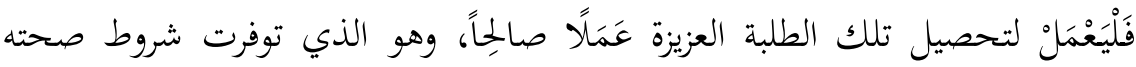

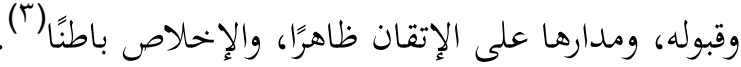

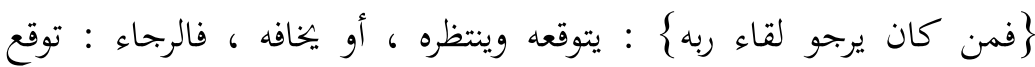
وصول الخير في المستقبل ، فمن جعل الرجاء على بابه ، فالمعنى : يرجو حسن لقاء ربه وأن يلقاه لقاء رضى وقبول. ومن حمله على معنى الخوف ، فالمعنى : يخاف سوء لقائه. 


\section{لقاء الله في القرآن الكريم ( دراسة موضوعية )}

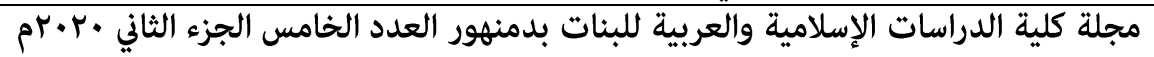

\section{المطلب الثالث : المنكروز للقاء الله، وعاقبة إنكارهم لله.}

إن أكثر الآيات التي سيقت في لقاء الله تعالى إنما كانت في المنكرين بلقاء

الله تعالى وعاقبتهم، وقد سبق شرح بعضها، وهاءنا أسرد بعض الآيات في هذا

$$
\text { المحال مع شرح يسير، وهي كما يلي: }
$$

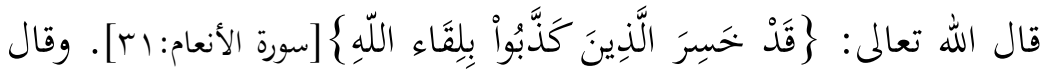

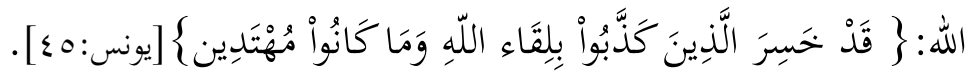

هذه الآيات فيها ذكر خسرن الكفار بسبب نكراهم للقاء الله تعالى. قال

مقاتل: قد خسر الذين كذبوا بلقاء الله يعني بالبعث حتى إذا جاءقم الساعة بغتة يعني يوم القيامة بغتة يعني فجأة قالوا يا حسرتنا يعني كفار قريش على ما فرطنا فيها يقولون: يا ندامتنا على ما ضيعنا في الدنيا من ذكر الله('). قال القشيري: غبن الذين جحدوا بالله، وبالبعث حين اختاروا العقوبة على الثواب حتى إذا جاءقم الساعة بغتة يعني: فجأة ومعناه: أهم جحدوا وثبتوا على جحودهم حتى إذا جاءهم القيامة قالوا: يا حسرتنا يعني: يا ندامتنا وخزينا والعرب إذا اجتهدت في المبالغة في الإخبار عن أمر عظيم تقع فيه جعلته نداء كقوله: يا حسرتنا ويا ويلتنا، ويا ندامتنا على ما فرطنا يعني: ضيعنا وتركنا العمل (؟). قال أبو جعفر الطبري: أخبر جل ثناؤه عن هؤلاء الكفرة بالبعث بما أخبر به عنهم، من طغياهم وترددهم فيه عند تعجيله إجابة دعائهم في الشر لو استجاب لهم، أن ذلك كان يدعوهم إلى التقرب إلى الوثن الذي يشرك به أحدهم، أو يضيف ذلك إلى أنه من فعله(ץ). 


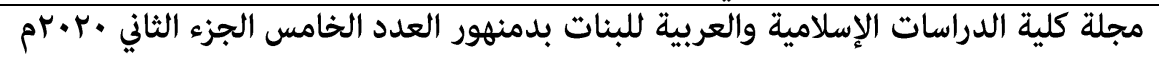

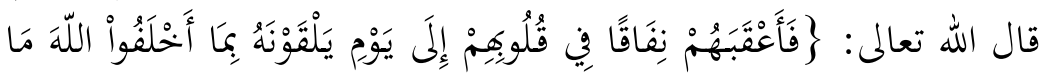

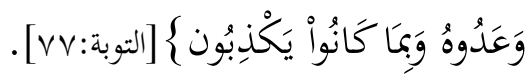

قال السمرقندي: فأعقبهم نفاقا في قلوبهم يقول جعل عاقبتهم إلى النفاق إلى يوم يلقونه يعني: يلقون الله، وهو يوم القيامة، بما أخلفوا الله ما وعدوه وبما كانوا يكذبون لقوله: لئن آتانا من فضله لنصدقن وقال عبد الله بن مسعود: (اعتبروا المنافق بثلاث: إذا حدث كذب، وإذا وعد أخلف، وإذا عاهد غدر)(')، ثم قرأ ومنهم من عاهد الله إلى قوله وبما كانوا يكذبون فقد ذكر الثلاثة في هذه الآية) (r) (20)

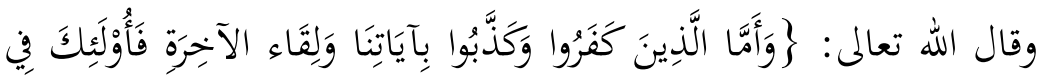

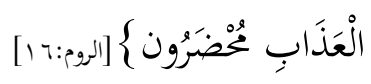

قال أبوجعفر الطبري: يقول تعالى ذكره: وأما الذين جحدوا توحيد الله، وكذبوا رسله، وأنكروا البعث بعد الممات والنشور للدار الآخرة، فأولئك في عذاب الله مخرون، وقد أحضرهم الله إياها، فجمعهم فيها ليذوقوا العذاب الذي كانوا

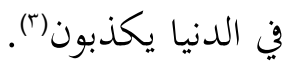
وبهذا أختم هذا المطلب الذي يحتوي نماذج ممن أنكر لقاء الله تعالى من الكفار، وكيف كان عاقبة إنكارهم.

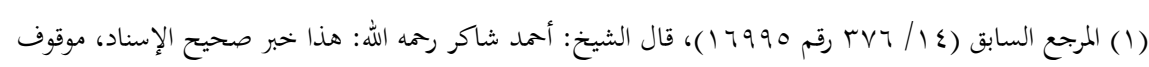

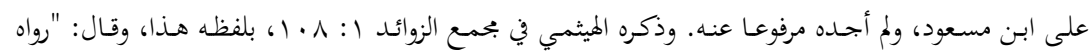

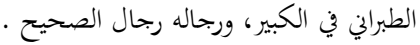

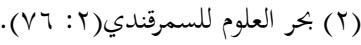

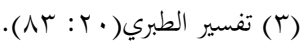


لقاء الله في القرآن الكريم ( دراسة موضوعية )

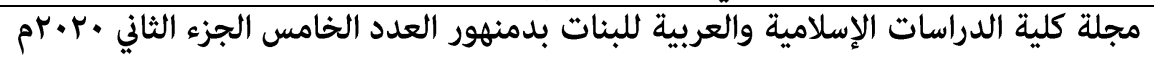

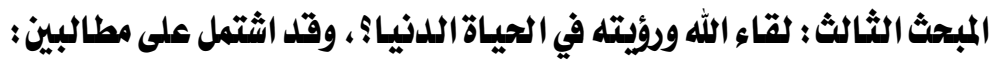

\section{المطلب الأول : هل يمكن لقاء الله في الحياة الدنيا؟.}

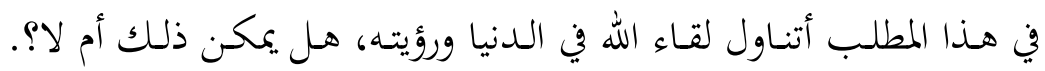

$$
\text { وفيه مسائل: }
$$

الأولى: أثبـت العلمـاء رؤية النبي صلى الله عليه وسـلم المنامية لربه - عز

وجل -، واعتمدوا في ذلك على الأحاديث الواردة بهذا الشأن؛ منها:

عن معاذ بن جبل - رضي الله عنه - قال: "احتبس عنا رسول الله صلى

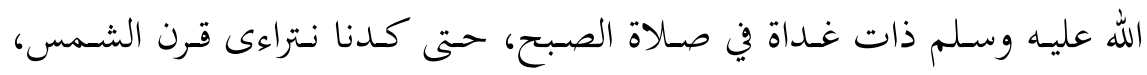
فخرج رسـول الله صسلى الله عليسه وسـلم سـريعا فثوّوب بالصـالاة، وصسلى وبتهوّز في

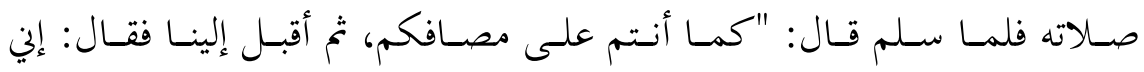

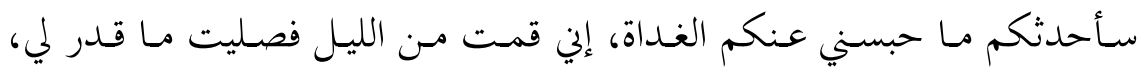
فنعست في صالاتي حتى استثقلت فإذا أنا بربي - عز وجل - في أحسن صورة.

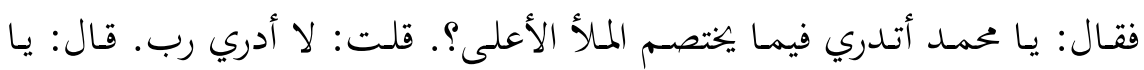
محمد فيم يختصم الملأ الأعلى؟ قلت : لا أدري ر. قال: يا محمد فيم يختصسم الملأ الأعلى؟ قلت: لا أدري رب. فرأيته وضع كفه بين كتفي حتى وجدت برد أنامله

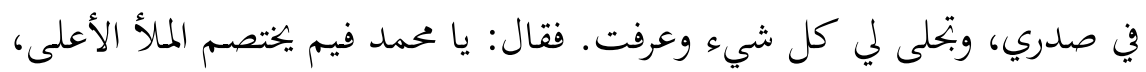

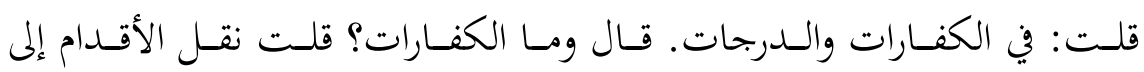
الجمعات، والجلوس في المساجد بعد الصلوات، وإسباغ الوضوء على الكريهات. قال: ومـا الدرجات؟ قلـت: إطعام الطعام، ولين الكـلام، والصـلاة والنـاس نيام.

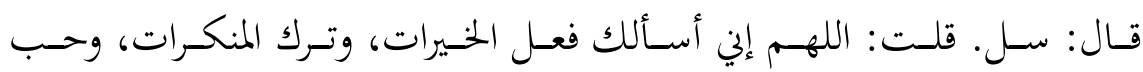

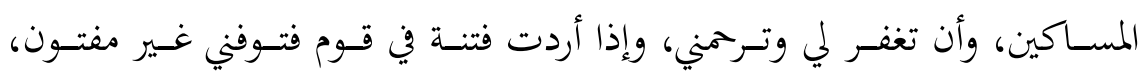

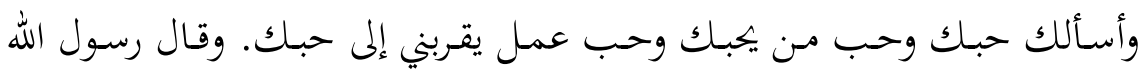
صلى الله عليه وسلم: إنها حق فادرسوها وتعلموها. 


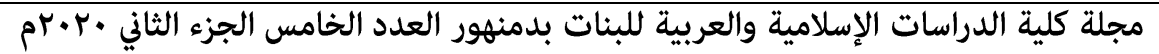

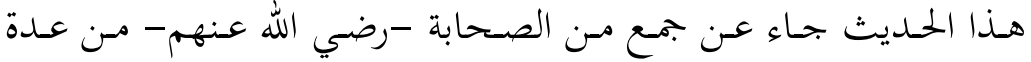

طرق منها: عن عبد الرحمن بن عائش عن مالك بن يخامر عن معاذ بن جبل رضي الله عنه - مرفوعا ('). الثانية: رؤية الله في الدنيا:

أهـل الســة والجماعـة يعتقـدون أن رؤيـة الله في الـدنيا جـائزة وممكنـة شـرعًا وعقـالً ولكن البشـر لا يقـدرون على رؤيتـه سبحانه والأدلة مـن الكتـاب والسـنة كثيرة منها قوله تعالى لموسى عليه السلام لما سأله أن ينظر إليه، فقال له ربه تبارك

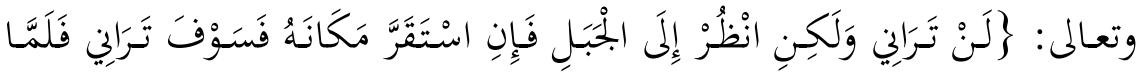

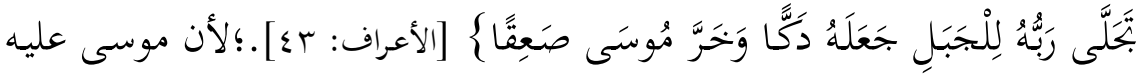
السالام سأل رؤية الله ولو كانت الرؤية مستحيلة لما سألها موسى لأنه كليم الرحمن وأعلم النـاس في وقته، فـل على أهـا ممكنة وجـائزة. ولو كانـت الرؤية مستحيلة لأنكر الله على موسى سؤالها، كما أنكر على نوح لما سأله لابنه، ولو كانـت الرؤية غير محكنـة لعلقها الله بـأمر غـير محكن، ولأجـاب موسى بجـواب يـلـل على عـدم إمكـان الرؤيسة، ولأن الله بتحلى للجبـل الـذي لا ثـواب لـه ولا عقـاب، فلـو كانـت الرؤيسة مسـتحيلة لــا بحلى لـهـ والرؤيـة محكنـة، ولكـن البشـر لا يقـدرون لضعفهم، فإذا كان يوم القيامة استطاعوا ذلك.

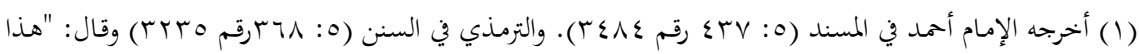

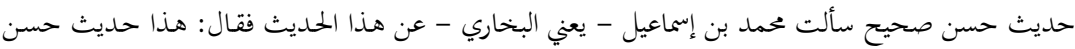

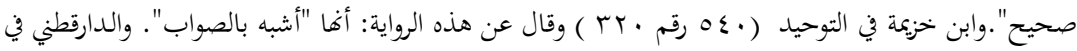

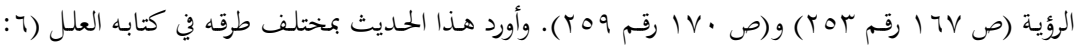

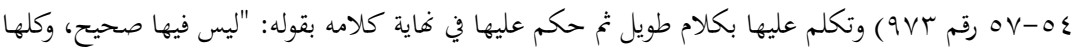




\section{لقاء الله في القرآن الكريم ( دراسة موضوعية )}

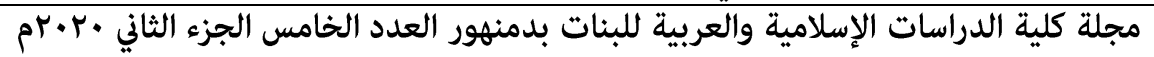

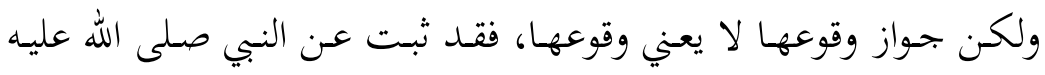
وسـلم كمـا في صسحيح مسـلم مـن حسديث عبــ الله بـن عمـر رضـي الله عنهمـا أن النبي - صلى الله عليه وسلم - قال: (وتعلموا أن أحدًا منكم لن يرى ربه حتى (') (يموت)

ولفذا لما يدعي الدجال أنه ربنا يرد عليه بهذا الحديث، بأننا لن نرى ربنا في الدنيا كما دل عليه هذا الحمديث.

قال شيخ الإسهلام ابن تيمية رحمه الله: "كل مـن ادعى أنه رأى ربه بعينه قبل الموت فدعواه باطلة باتفاق أهل السنة والجماعة، لأهم اتفقوا جميعهم على أن إن إنها

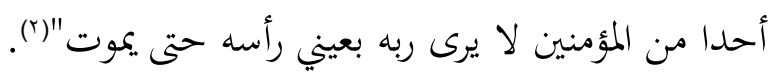

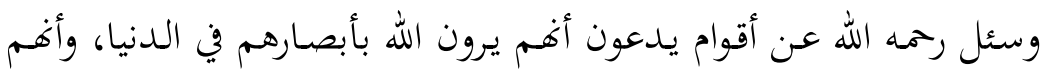
يكصل لهم بغير سؤال ما حصل لموسى بالسؤال؟ فأجاب: أجمع سلف الأمة وأثمتها على أن المؤمنين يرون الله بأبصارهم في الآخرة، وأجمعوا على أهم لا يرونه في الدنيا بأبصارهم، ولم يتنازعوا إلا في النبي -

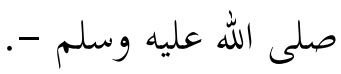
ومسن قـال مـن النـاس: إن الأوليـاء أو غـيرهم يـرى الله بعينـه في الـدنيا فهـو مبتدع ضال مخالف للكتاب والسنة وإبماع سلف الأمة، لا سيما إذا ادعوا(؟). الثالث: هل رأى النبي - صلى الله عليه وسلم - ربه يقظة؟ صله

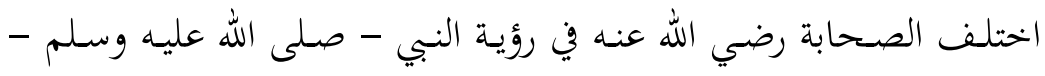
لربه ليلة المعراج على قولين:

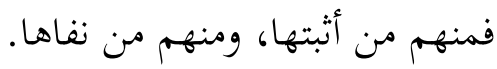

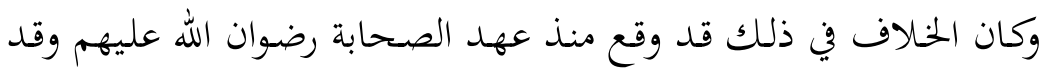
شـدت عائشـة رضي الله عنها النكير على مـن قال بأن الرسول صـلى الله عليه 


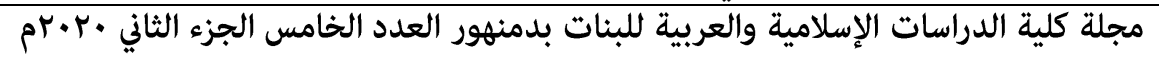

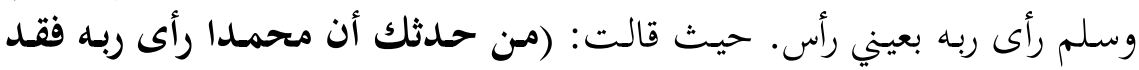

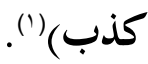

أما من عداه من الحلق فلم يقع خحلاف بين العلماء في عدم وقوعها لهم،

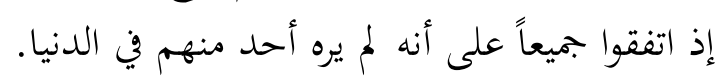
قال الإمام البربهاري: "ومن زعم أنه يرى ربه في دار الدنيا؛ فهو كافر بـاله

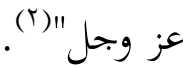

قال شيخ الإسـلام ابن تيمية: "وكذلك كل مـن ادعى أنه رأى ربه بعينه

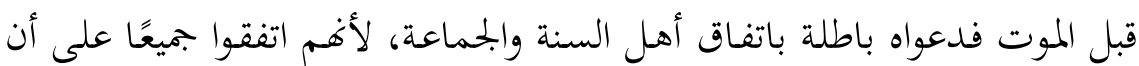

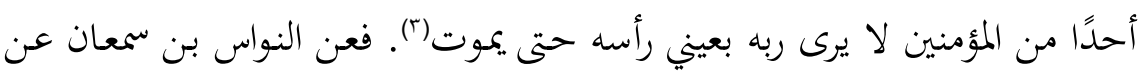

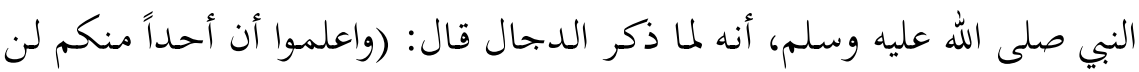

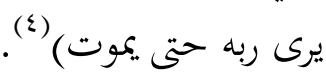
وقال أيضـاً: وقد اتفق المسلمون على أن النبي صلى الله عليه وسلم لم ير ربه بعينه في الأرض، وأن الله ينزل له إلى الأرض، وليس عن النبي صلى الله عليه وسلم قط حديث فيه أن الله نزل له إلى الأرض(0) بل الأحاديث الصحيحة: (أن

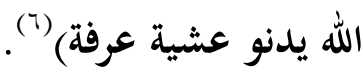
ووي رواية "(إلى سـماء الدنيا كل ليلة حسين يبقى ثلـث الليل الأخيـر، فيقول: من يدعوني فأستجيب له؟ من يسألني فأعطيه؟ من يستغفرني فأغفر

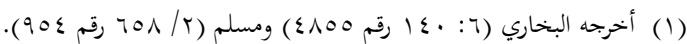

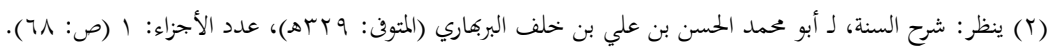

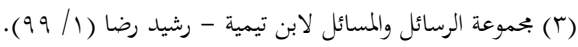

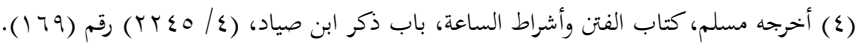

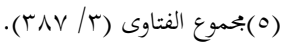

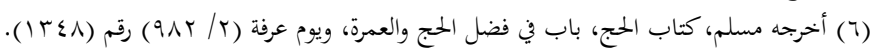

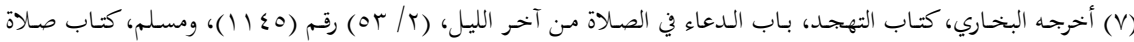

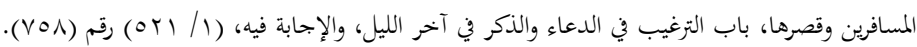




\section{لقاء الله في القرآن الكريم ( دراسة موضوعية )}

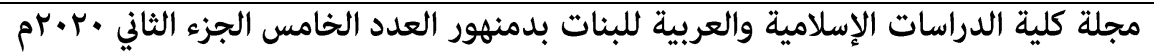

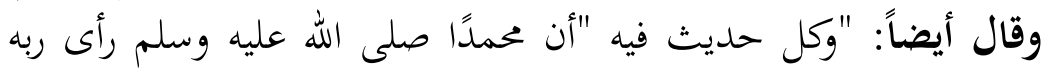
بعينه في الأرض"، فهو كذب باتفاق المسلمين وعلمائهم، هذا شيء لم يقله أحد

$$
\text { من علماء المسلمين ولا رواه أحد منهم. }
$$

وقال أيضًا: "وبالجملة أن كل حديث فيه أن النبي صلى الله عليه وسلم رأى ربه بعينيه في الأرض، وفيه أنه نزل له إلى الأرض، وفيه أن رياض الجنة خطوات الحق، وفيه أنه وطئ على صخرة بيت المقدس، كل هذا كذب باطل بل باتفاق علماء

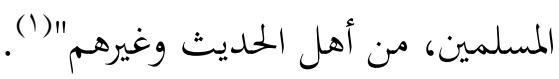

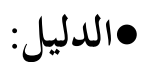

قال تعالي لموسى: جرَن تَرَاني

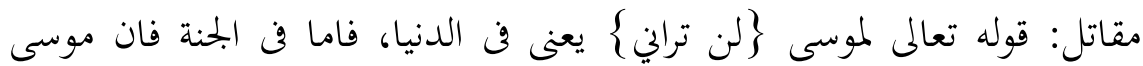

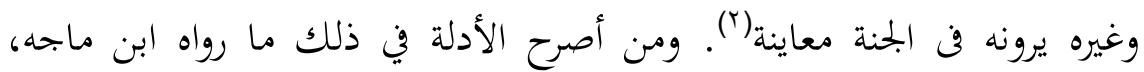
والنسائي والحاكم وغيرهم مرفوعا: (إنكم لن تروا ربكم حتى تموتوا)(؟) فالدنيا ليست محل الرؤية؛ لأن الرؤية نعيم، رؤية الله أعلى نعيم أهل الجنة وهذه الدار ليست دار النعيم، دار الأكدار ودار الأحزان ودار التكليف فلا يرى في الدنيا لكنه يرى في الآخرة يراه المؤمنون. قال ابن أبي زيد القيرواني: والجواب من أوجحه: الأول: أن المعنى لا تدركه الأبصار، أي في الدنيا، فلا ينافي الرؤية في

الثاني: وهو الحق: في قوله \}ََن تَرَاني المشعر بالإحاطة بالكنه. أما مطلق الرؤية فلا تدل الآية على نفيه، بل هو ثابت

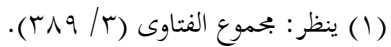

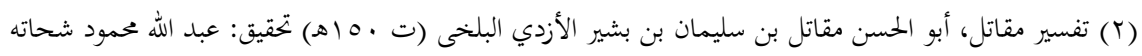

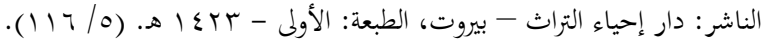

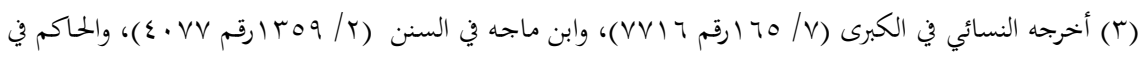

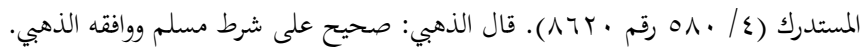




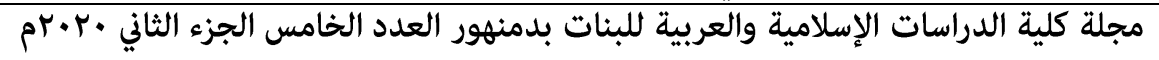

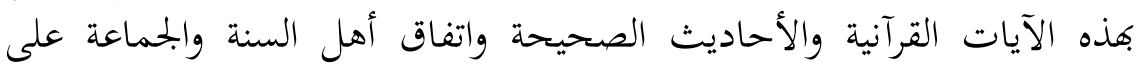
ذلك.

وحاصل هذا الجحواب: أن الإدراك أخص من مطلق الرؤية، لأن الإدراك

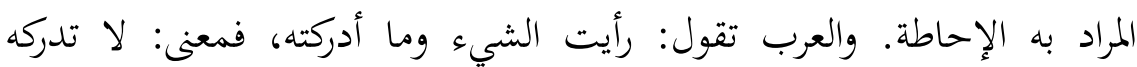
الأبصار:

لا تحيط به، كما أنه تعالى يعلمه الخلق، ولا يجيطون به علمًا'('). وقد اتفق العقلاء على أن نفي الأخص، لا يستلزم نفي الأعم، فانتفاء الإدراك لا يلزم منه انتفاء مطلق الرؤية، مع أن الله تعالى لا يدرك كنهه على الحقيقة أحد

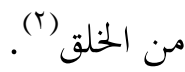
والـدليل على صسحة هـذا الوجـه مـا أخرجـه مسـلم وغسيره مسن حسديث

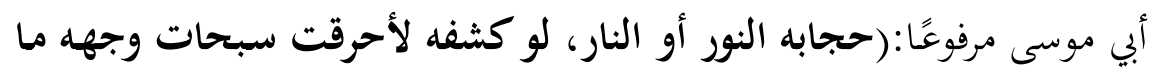

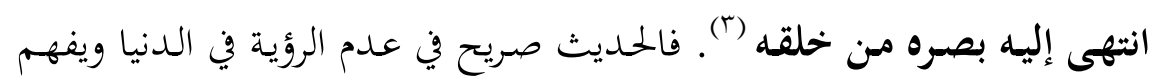
منه عدم إمكان الإحاطة مطلقًا).

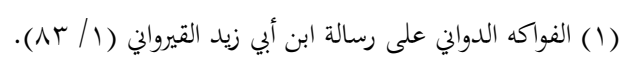

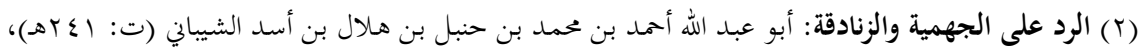

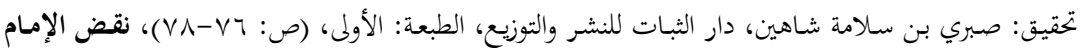

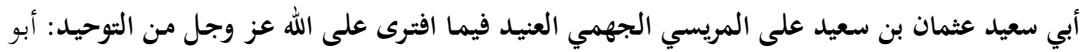

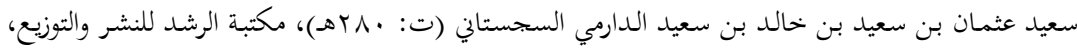

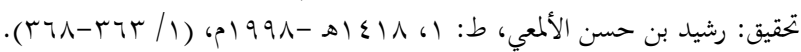

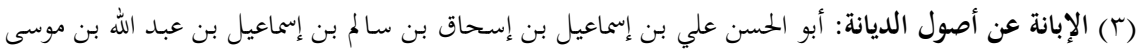

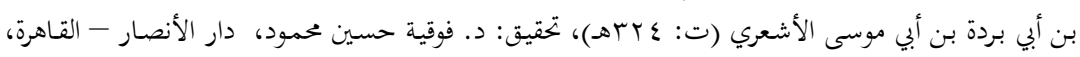

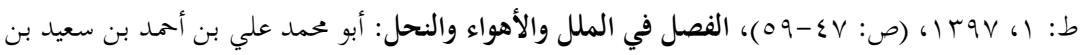

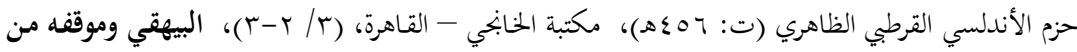

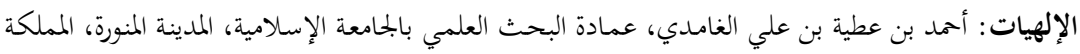

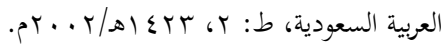




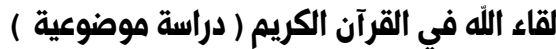

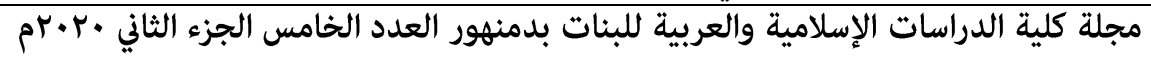

\section{المطلب الثاني : كالام الله لموسى عليه السلام}

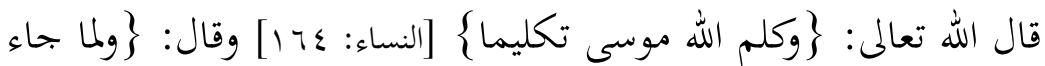

موسى لميقاتنا وكلمه ربه $[$ الأعراف: rعا1] وقال جل وعلا: \}وناديناه من جانب

الطور الأيمن وقربناه بجيا؛ [سورة مريم: ب ه] وقال: \} فلما أتاها نودي يا موسى إين أنا ربك فاخلع نعليك إنك بالواد المقدس طوى وأنا اخترتك فاستمع لما يوحى [سورة طه: 11 1 ]. فهذه الآيات دليل كلام الله تعالى لموسى في الدنيا، ودل الدليل على أنه ناداه والنداء لا يكون إلا صوتا مسموعا فلا يعقل في لغة العرب لفظ النداء بغير صوت مسموع لا حقيقة ولا بحازا انتهى. وقال الإمام موفق الدين بن قدامة في قوله تعالى وكلم الله موسى تكليما \} إذ ناداه ربه بالواد المقدس طوى \{ أجعنا على أن موسى عليه السلام سمع كلام الله تعالى من الله لا من شجرة ولا من حجر ولا من غيره لأنه لو سمع من غير الله تعالى لكان بنو إسرائيل أفضل في ذلك منه لأهم سمعوا من أفضل ممن سمع منه موسى لكوهم سمعوا من موسى عليه السالام وهو على زعمهم إنما سمع من الشجرة ثم يقال لهم لم سمي موسى كليم الله وإذا ثبت أن موسى عليه السالام إنما سمع من الله عز وجل لم يجز أن يكون الكاملام الذي سمعه إلا صوتا وحرفا فإنه لو كان معنى في النفس وفكرة ورؤية لم يكن ذلك تكليما لموسى ولا هو شئ يسمع، والفكر لا يسمى مناداة('). وكذا قال الإمام أبو الحسن الأشعري(؟).

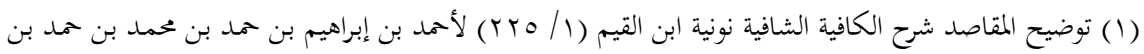

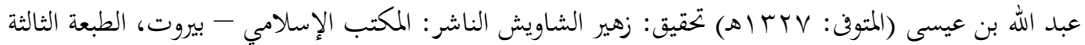




\section{لقاء الله في القرآن الكريم ( دراسة موضوعية )}

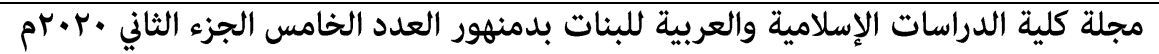
وهذا التكليم كان من وراء حجاب وكان الله يُسمع موسي صوته بمشيئته وقُدرته وهو القادر على كُل شيء، فكلامه منه بدا بلا كيفية قولا، أي: ظهر منه ولا ندري كيفية تكلمه به. فكان سيدنا موسى عليه السلام يسمع الصوت، وقال

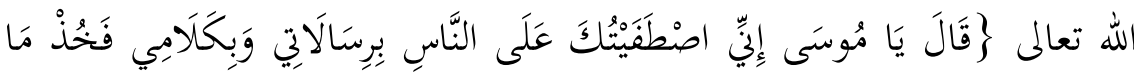

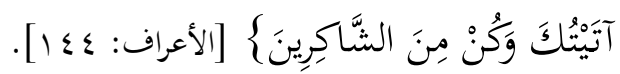
قال البربهاري: والإيمان بأن الله تبارك وتعالى هو الذي كلم موسى بـن عمـران يـوم الطـور وموسىى يسـمع مـن الله الكـلام بصـوت وقع في مسـامعه منسه

$$
\text { لا من غيره، فمن قال غير هذا فقد كفر (1). }
$$

قال الطبري: وأما قوله: (وكلم الله موسى تكليما\{، فإنه يعني بذلك جل ثناؤه: وخاطب الله بكلامه موسى خطابا، وساق الطبري مرويات عدة عن الصحابة والتابعين في ذلك وكاطن.

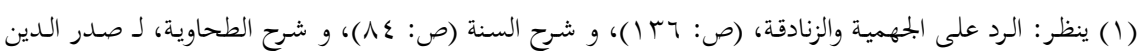

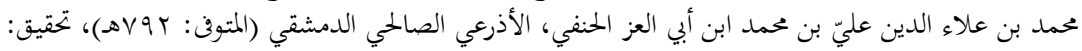

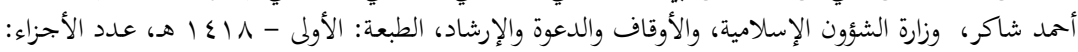

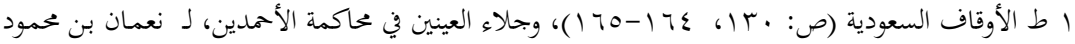

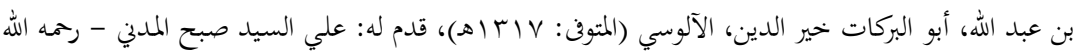

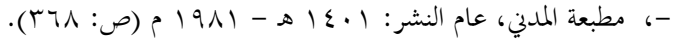

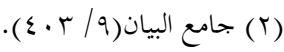


لقاء الله في القرآن الكريم ( دراسة موضوعية )

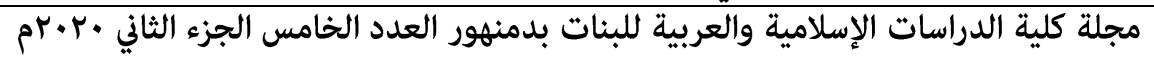

\section{المبحث الرابع : مراتب لقاء الله تعالى في الاخرة.}

\section{المطلب الأول : مراتب لقاء المؤمنيز الله في الآخرة.}

جعل الله للإنسان ثلاث مراحل: مرحلة الدنيا: وهي المرحلة التي يمياها، ويعمل فيها، وليس فيها لقاء مع الله؛ لأها مرحلة عمل ولا حساب، ومرحلة البرزخ: وهي التي يكون بين الدنيا والآخرة، وهي حياة القبر، وهي أول لقاء العبد

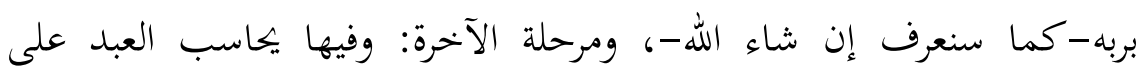
أعماله، فإما جنة، وإما نارًا، وفيها يظفر أهل الجنة برؤية الله-عز وجل -ولقائه، فما هي مراتب لقاء العبد بربه في الآخرة؟، وهل هناك لقاء في القبر؟، وهذا ما سيتضح لنا-إن شاء الله-من خلاءل النقاط الأتية: أولا : لقاء الروح بعد الموت (صعود الروح إلى باريها سبحانه) أوّل لقاء بين العبد وربه يكون بعد الموت، فتصعد الروح إلى السماء، للقاء ربها، ولا يقصد بهذا اللقاء رؤية الله-عز وجل -لأن الرؤية لا تكون إلا في الآخرة، وإنما يكون المقصود باللقاء-والله أعلم-البشارات التي يعاينها العبد، والفوز بما أعده الله له من نعيم في القبر، وإلى ذلك جاءت الإشارة في الحديث الذي رواه عبادة بن الصامت، عن النبي صلى الله عليه وسلم أنه قال: (من أحب لقاء الله أحب الله لقاءه، ومن كره لقاء الله كره الله لقاءه) قالت عائشة، أو بعض أزواجه: إنا لنكره الموت، قال: اليس ذاك، ولكن المؤمن إذا حضره الموت بشر برضوان الله وكرامته، فليس شيء أحب إليه محا أمامه، فأحب لقاء الله وأحب الله لقاءه، وإن الكافر إذا حضر بشر بعذاب الله وعقوبته، فليس شيء أكره إليه محا أمامه، كره لقاء الله وكره الله لقاءه) (1).

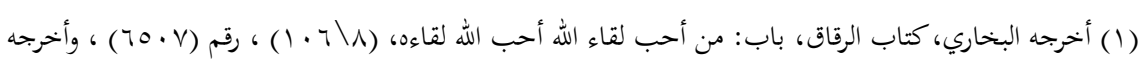

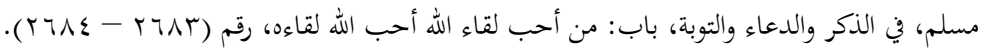


لقاء الله في القرآن الكريم ( دراسة موضوعية )

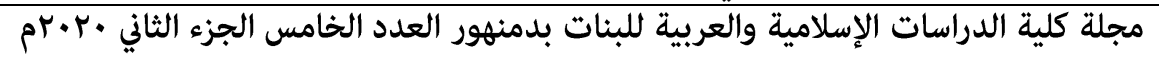

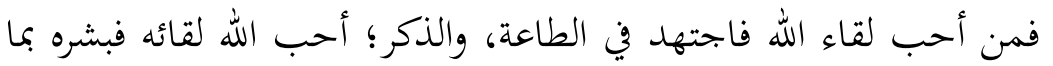
أعده له من نعيم في القبر، فيكون هذا أوّل لقاء له مع الله في الحساب، فالقبر الحبه أوّل منزلة من منازل الآخرة.

فالعبد بعد موته إذا كان زاهدً في الدنيا، وراغبًا في الآخرة، أتته الملائكة فتحمل روحه إلى السماء، فتستبشر بها المالائكة، ويصدر منها رائحة طيبة، فتلقي

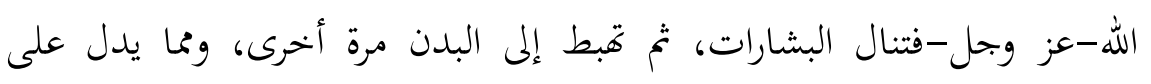
صعود الروح، ما رواه البراء بن عازب رضي الله عنه قال: خرجنا مع رسول الله صلى الله عليه وسلم في جنازة رجل من الأنصار فانتهينا إلى القبر، وملا يلحد فجلس رسول الله صلى الله عليه وسلم، وجلسنا حوله، كأنما على رووسنا الطير، وفي يده عود ينكت به فرفع رأسه، فقال: (استعيذوا بالله من عذاب القبر)، ثلاث مرات، أو مرتين، ثم قال: " (إن العبد المؤمن إذا كان في انقطاع من الدنيا، وإقبال من الآخرة، نزل إليه من السماء مالائكة بيض الوجوه، كأن وجوههم الثمس، حتى يجلسون منه، مد البصر معهم كفن من أكفان الجنة، وحنوط من حنوط الجنة، ثم يجيء ملك الموت فيقعد عند رأسه فيقول: أيتها النفس الطيبة اخرجي إلى مغفرة من الله ورضوان، فتخرج تسيل كما تسيل القطرة من في السقاء، فإذا أخذوها لم يدعوها في يده طرفة عين، حتى يأخذوها فيجعلوها في ذلك الكفن، وذلك الحنوط، فيخرج منها كأطيب نفخة مسك، وجدت على وجه الأرض، فيصعدون بها فلا يمرون بها على ملك من المالئكة، إلا قالوا: ما هذا الروح الطيب؟ فيقولون: هذا فلان بن فلان بأحسن أسمائه التي كان يسمى بها في الدنيا حتى ينتهون بها إلى السماء الدنيا فيستفتح فيفتح لهم فيستقبله من كل سماء مقربوها إلى السماء التي تليها حتى ينتهي به إلى السماء السابعة قال: فيقول الله: اكتبوا 
لقاء الله في القرآن الكريم ( دراسة موضوعية )

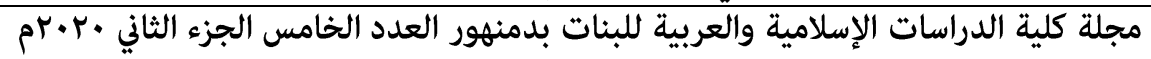

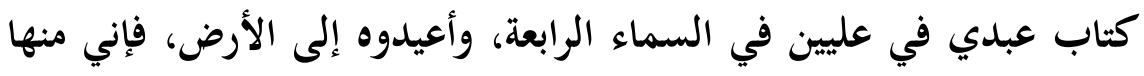
خلقتهم، وفيها أعيدهم، ومنها أخرجهم تارة أخرى، فتعاد روحه في جسده، ويأتيه ملكان فيجلسانه فيقولان له: من ربك؟ فيقول: ربي الله، فيقولان له: ما دينك؟ فيقول: ديني الإسلام، فيقولان له: ما هذا الرجل الذي بعث فيكم؟ فيقول: هو رسول الله صلى الله عليه وسلم، فيقولان: ما عملك؟ فيقول: قرأت كتاب الله، وآمنت به، وصدقت به، فينادي مناد من السماء أن صدق عبدي فأفشوه من الجنة، وألبسوه من الجنة، وافتحوا له بابا إلى وهي الجنة فيأتيه من طيبها، وروحها، ويفسح له في قبره مد بصره، ويأتيه رجل حسن الوجه حسن الثياب طيب الريح، فيقول: أبشر بالذي يسرك هذا يومك الذي كنت توعد، فيقول: ومن أنت؟ فوجهك الوجه الذي يجيء بالخير، فيقول: أنا عملك الصالح فيقول: رب أقم الساعة، أقم الساعة، حتى أرجع إلى أهلي، ومالي....) (1). ثانيا: لقاء الجسد في القيامة وفي الجنة: بعد أن يأذن الله بالقيامة، يعود البدن إلى الروح مرة أخرى، كما كان في

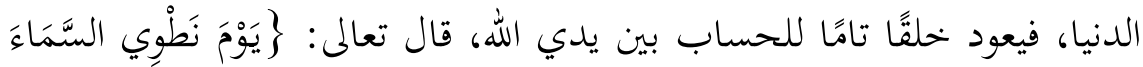

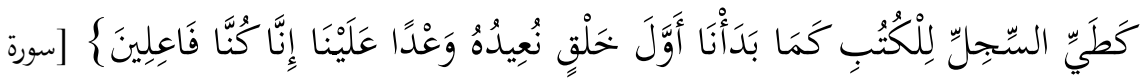

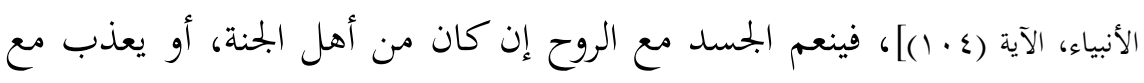
الروح إن كان من أهل النار.

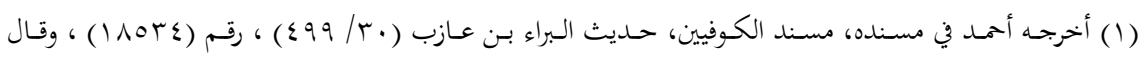

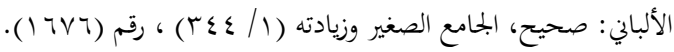




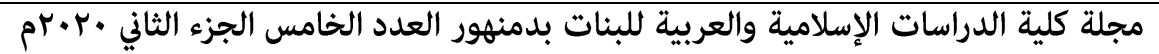

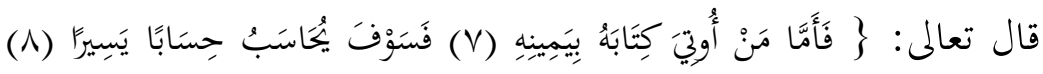

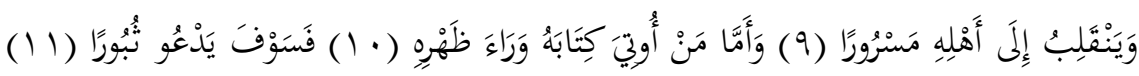

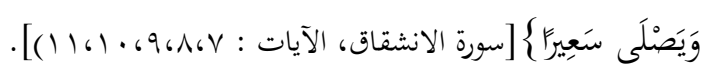

عن عدي بن حاتم، قال: قال رسول الله صلى الله عليه وسلم: ما منكم أحد إلا سيكلمه ربه ليس بينه وبينه ترجمان، فينظر أيمن منه فلا يرى إلا ما قدم من عمله، وينظر أشأم منه فلا يرى إلا ما قدم، وينظر بين يديه فلا يرى إلا النار تلقاء وجهه، فاتقوا النار ولو بشق تمرة "، قال الأعمش: وحدثني عمرو ابن مرة، عن خيثمة، مثله، وزاد فيه: 》ولو بكلمة طيبة)| (1). ثالثا: تجلي الله تعالى لأهل الجنة: الجنة نعيمها دائم، وفيها أضعاف ما يتخيل الإنسان، ولكن النعيم الأكبر، والثواب الأعظم، هو النظر إلى وجهه الكريم، فالأنسان يريد أن يرى ربه الذي عبده، وصام وقام حبًا فيه، وجاهد في سبيله بنفسه وماله تقربًا إليه، فغاية مراد المؤمن أن يظفر برؤية ربه وخالقه، يريد أن يرى هذا الإله العظيم، الذي خلق هذا الكون فأبدعه ونظّمه على غير مثال، ورؤية الله -عز وجل -ثابتة بالقرآن والسنة،

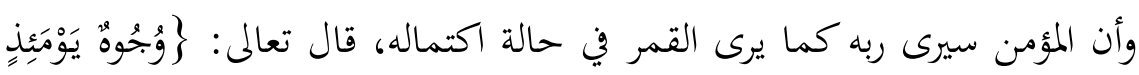

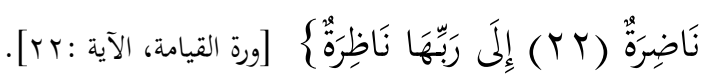

أي: تنظر إلى ربها على حسب مراتبهم: منهم من ينظره كل يوم بكرة وعشيا، ومنهم من ينظره كل جمعة مرة واحدة، فيتمتعون بالنظر إلى وجهه الكريم، وجماله الباهر، الذي ليس كمثله شيء، فإذا رأوه نسوا ما هم فيه من النعيم وحصل لمم من اللذة والسرور ما لا يمكن التعبير عنه، ونضرت وجوههم فازدادوا

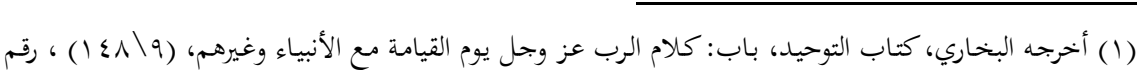

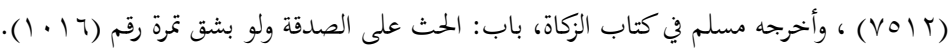




\section{لقاء الله في القرآن الكريم ( دراسة موضوعية )}

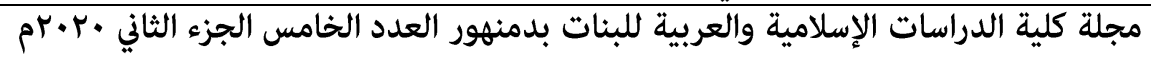

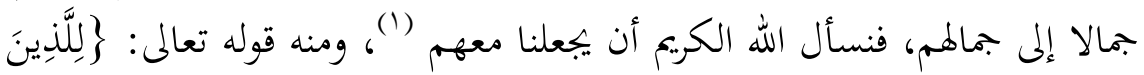

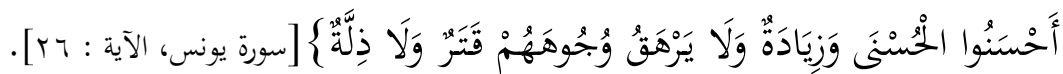
للذين أحسنوا يعني: وحدوا الله، الحسنى يعني: الجنة، وزيادة يعني: فضل على الجنة، النظر إلى وجه الله الكريع، ولا يرهق وجوههم قتر، يعني: ولا يصيب وجوههم سواد ويقال: كسوف، ويقال: هو السواد، ولا ذلة، يعني: ولا مذلة في أبداهم عند معاينة النار، أولئك الذين هم بهذه المنزلة، أصحاب الجنة هم فيها خاللدون (r) (ب) عن جرير بن عبد الله، قال: كنا عند النبي صلى الله عليه وسلم، فنظر إلى القمر ليلة -يعني البدر -فقال: (إنكم سترون ربكم، كما ترون هذا القمر، لا تضامون في رؤيته، فإن استطعتم أن لا تغلبوا على صالاة قبل طلوع الشمس وقبل غروبها فافعلوا) ثم قرأ: (وسبح بحمد ربك قبل طلوع الشمس وقبل الغروب ففي الحديث دلالة صريحة على أن المؤمن سيرى ربه كما يرى القمر في حالة اكتماله، فهل يوجد نعيم أفضل من رؤية الله-عز وجل -؟ فأهل الجنة لا يعطون فيها شييًا أحب إليهم من النظر إلى وجه الكريم. ولا شك أن الرؤيا من لوازمها لقيا الله تعالى، ولا سيما أن الله تعالى لما يتجلى لعباده يخاطبهم وهـم يرونه.

$$
\begin{aligned}
& \text { (1) (1) تيسير الكريم الرحمن في تفسير كلام المنان، (ص999). }
\end{aligned}
$$

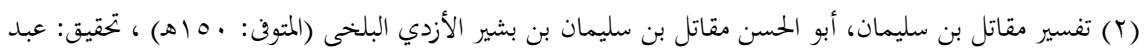

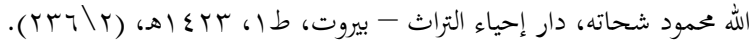

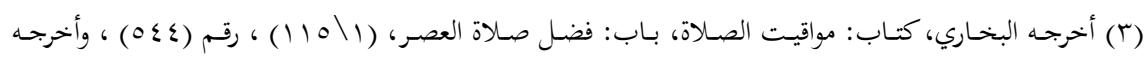

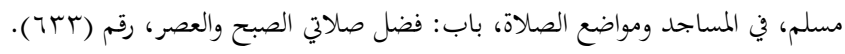




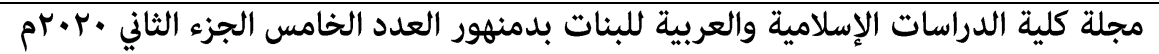

\section{المطلب الثاذي : مراتب لقاء الكافرين الله.}

سبق القول بأن لإٕنسان ثلاث مراحل: مرحلة الدنيا: وهي المرحلة التي

يجياها، ويعمل فيها، وليس فيها لقاء مع الله؛ لأها مرحلة عمل ولا حساب،

ومرحلة البرزخ: وهي التي يكون بين الدنيا والآخرة، وهي حياة القبر، وهي أول

لقاء العبد بربه-كما سنعرف إن شاء الله-، ومرحلة الآخرة: وفيها يحاسب العبد

على أعماله، فإما جنة، وإما نارًا، وفيها يظفر أهل الجنة برؤية الله-عز وجل -

ولقائه، فما هي مراتب لقاء العبد بربه في الآخرة؟، وهل هناك لقاء في القبر؟،

وهذا ما سيتضح لنا-إن شاء الله-من خلال النقاط الأتية:

أولا : لقاء الروح بعد الموت (صعود الروح إلى باريها سبحانه)

وسبق في الحديث: (من أحب لقاء الله أحب الله لقاءه، ومن كره لقاء

الله كره الله لقاءه) قالت عائشة، أو بعض أزواجه: إنا لنكره الموت، قال: اليس

ذاك، ولكن المؤمن إذا حضره الموت بشر برضوان الله وكرامته، فليس شيء أحب

إليه مما أمامه، فأحب لقاء الله وأحب الله لقاه، وإن الكافر إذا حضر بشر بعذاب الله وعقوبته، فليس شيء أكره إليه محا أمامه، كره لقاء الله وكره الله

لقاءه) (1)

فمن أحب لقاء الله فاجتهد في الطاعة، والذكر؛ أحب الله لقائه فبشره بما

أعده له من نعيم في القبر، فيكون هذا أوّل لقاء له مع الله في الحساب، فالقبر أوّل منزلة من منازل الآخرة.

فالعبد بعد موته إذا كان زاهدً في الدنيا، وراغبًا في الآخرة، أتته الملائكة فتحمل روحه إلى السماء، فتستبشر بها الملائكة، ويصدر منها رائحة طيبة، فتلقي

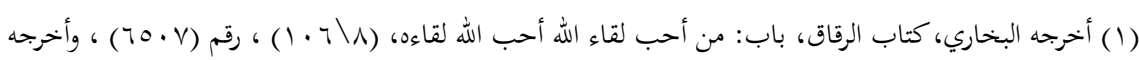

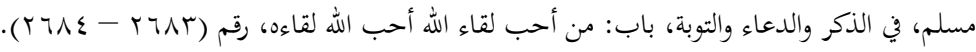




\section{لقاء الله في القرآن الكريم ( دراسة موضوعية )}

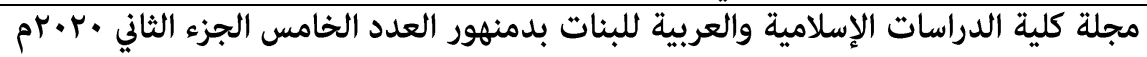

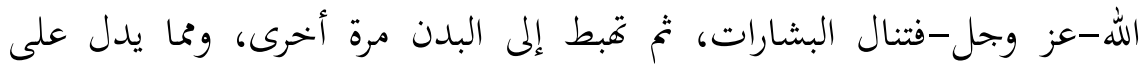
صعود الروح، ما رواه البراء بن عازب رضي الله عنه قال: خرجنا مع رسول الله

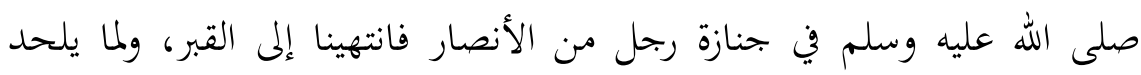

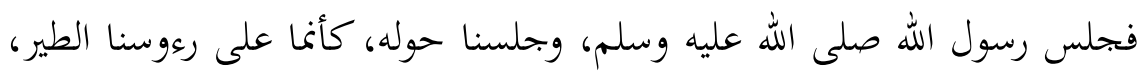
وفي يده عود ينكت به فرفع رأسه، فقال: (استعيذوا بالله من عذاب القبر)، ثلاث مرات، أو مرتين، ثم قال: " (إن العبد المؤمن إذا كان في انقطاع من الدنيا، وإقبال من الآخرة... وإن الكافر إذا كان في انقطاع من الدنيا، وإقبال من الآخرة، نزلت عليه ملائكة غلاظ شداد، فانتزعوا روحه، كما ينتزع السفود الكثير الشعب من الصوف المبتل، وتنزع نفسه مع العروق، فيلعنه كل ملك بين السماء والأرض، وكل ملك في السماء، وتغلق أبواب السماء، ليس من أهل باب، إلا وهم يدعون الله: أن لا تعرج روحه من قبلهم، فإذا عرج بروحه، قالوا: رب فلان بن فلان عبدك، قال: أرجعوه، فإني عهدت إليهم أني منها خلقتهم، وفيها أعيدهم، ومنها أخرجهم تارة أخرى، قال: فإنه ليسمع خفق نعال أصحابه، إذا ولوا عنه، قال: فيأتيه آت فيقول: من ربك؟ ما دينك؟ من نبيك؟ فيقول: لا أدري، فيقول: لا دريت ولا تلوت، ويأتيه آت قبيح الوجل، قبيح الثياب، منتن الريح فيقول: أبشر بهوان من الله، وعذاب مقيم، فيقول: وأنت، فبشرك الله بالشر من أنت؟ فيقول: أنا عملك الخبيث، كنت بطيئا عن طاعة الله، سريعا في معصية الله، فجزاك الله شرا، ثم يقيض له أعمى أصم أبكم في يده مرزبة، لو ضرب بها جبل كان ترابا، فيضربه ضربة حتى يصير ترابا، ثم يعيده الله كما كان، 


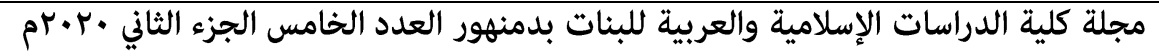

فيضربه ضربة أخرى، فيصيح صيحة يسمعه كل شيء إلا الثقلين ".

قال البراء بن عازب: " ثم يفتح له باب من النار ويمهد من فرش النار ( ).

$$
\text { ثانيا: الثقاء الأجساد والأرواح في الآخرة }
$$

قال الله تعالى: \}قد خسر الذين كذبوا بلقاء الله : في هذه الآية حكم من الله تعالى بخسران المكذبين وتعجيب من حالهم حيث لم يستعدوا ليوم الدين بالإيمان وعمل الصالحات المزكية للنفوس، وآتروا عليها الدنيا القصيرة الأمد، المليئة بالأكدار، والتي يروها يوم الحشر كأها ساعة من هار، وقد بين الله تعالى ضلالهم فيما ذهبوا إليه فقال: \}وما كانوا مهتدين\{: أي وما كانوا مهتدين إلى الصواب فيما ذهبوا إليه واختاروه لأنفسهم، من إيثارهم الفانى على الباقي. وهو الأعمال الصالحة التي هي ثمرات الإيمان الصحيح. والعاقل من يستعمل عقله ويأخذ حذره، ويختار الأصلح والأنفع والأبقى، والمقصود من لقاء الله: حسابه وجزاؤه في

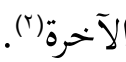

ثالثا: تجلي الله للكفار يوم القيامة:

اختلـف العلمــاء هـلـ الكفــار يــرون الله عـز وجــل في موقـف القيامــة

أو لا يرونسه؟ على ثالثة أقوال: قيـل: لا يـراه إلا المؤمنسون فتـط؛ استـلالاً بقوله تعالى: $\}$ الموقـف كلهـم مـؤمنهم وكـافرهم ثم يحتجهـب عـن الكفــار. وقــد سـئل الشـيخ عبـد الـرزاق عفيفـي رحمـه الله: هـل الكفــار يـرون الله في المحشـــ فقـال الشـيخ

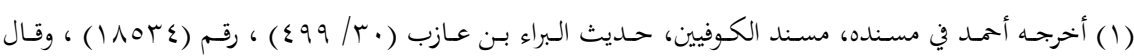

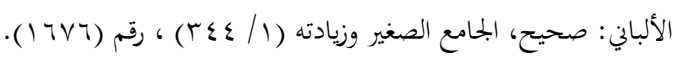




\section{لقاء الله في القرآن الكريم ( دراسة موضوعية )}

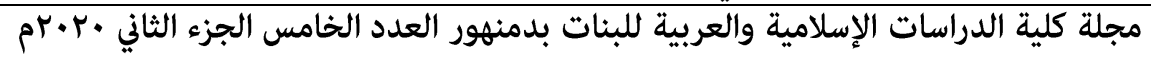

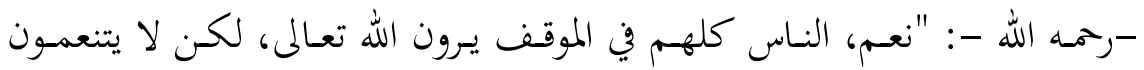
بالرؤية حتى أطيب عباد الله لأهم يكونون في بلاء وكرب. أمـا الرؤيـة التي فيها نعمـة فهي في الجنـة، والرؤيـة في المحشر ليست خحاصـة بالمنـافقين بـل تعـم أنسواع الكفــار ". فتـاوى ورسـائل سماحسة الشـيخ عبــ الـرزاق

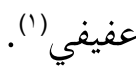
وقيـل: لا يـراه إلا المؤمنـون والمنـافقون فقـط؛ لأن المنـافقين كـانوا معهـم في الدنيا، ولأحاديث وردت بأهم يكونون معهم حتى يروا الله ثم يسجدون لله، فيأتي المنـافق فيستجد فيكـون ظهره طبقـاً ولا يستطيع السجود، وذلك قول الله تعـالى:

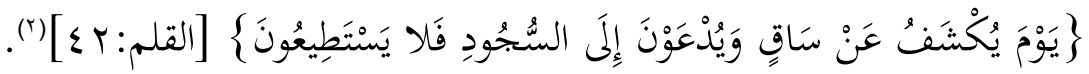

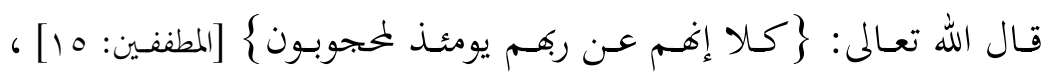
فجعل احتجابه عنهم عقوبة لهم فإذا احتجب عن الأولياء والأعداء، فأي فضل لأولياء على الأعداء. 


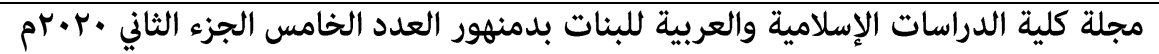

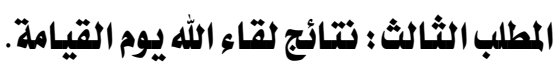

سبق في المبحـث الثـاني ذكر المؤمنين بلقـاء الله وذكر الكـافرين بلقـاء الله تعالى وعاقبة كل فريق منهم، ففريق المؤمنين ينعمون بلقاء الله وفريق الكافرين يلقى الخسران المبين.

أولا: نتائج المؤمنين بلقاء الله تعالى: من أبرز نتائج لقاء الله تعالى للمؤمنين: 1 - رؤيـة الله عز وجـل وقـد سبق أن مـن لـوازم لقـاء الله تعـالى الرؤيـة إلى وجـه الله

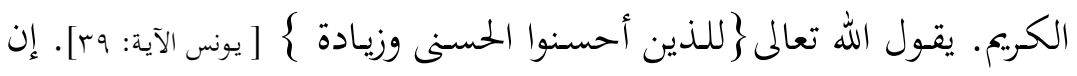
أنعهم مـا يكرم بـه أهـل الجنـة هـو : رؤيسة الله تعـالى، والتلذذذ بـالنظر إلى وجهـه

$$
\text { r - استبشارهم وبياض وجوههم: }
$$

مــن بشـارات أهـل الجنــة في الآخــرة، أن الله يجعــل وجــوههم بيضــاء، يستبشرون بنعمة منه وفضل، فيظهر الله أعمالهم الصالحة على وجوههم، فتعرفهم بسيماهـم، وقد يظن الإنسـان أن البياض والسـواد في الـدنيا، تفريق بـين مـن يحبـه

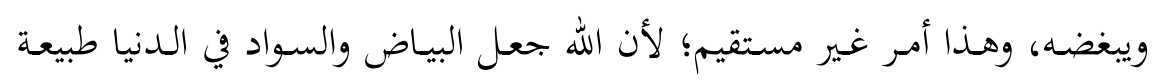
تتناسب مع البيئة التي ولد فيها الإنسان، ولأن الله حدد منهج الأفضلية عنده من

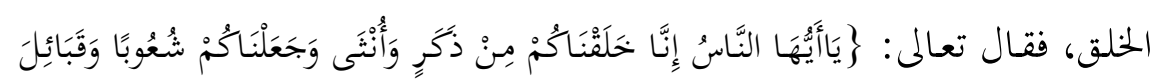

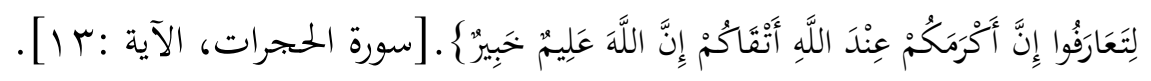
ولكن البياض والسواد في الآخرة علامة على أهل الجنة، وأهل النار، قال

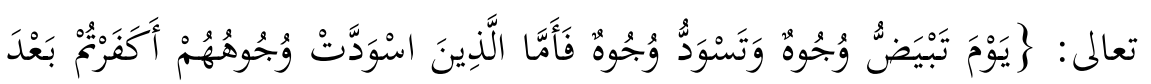

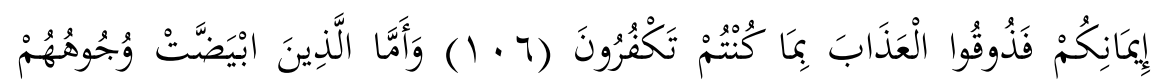

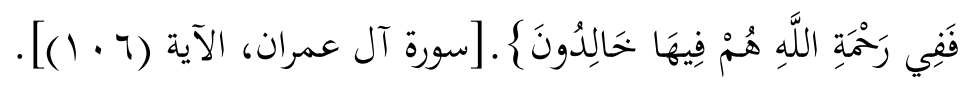




\section{لقاء الله في القرآن الكريم ( دراسة موضوعية )}

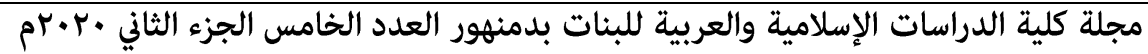

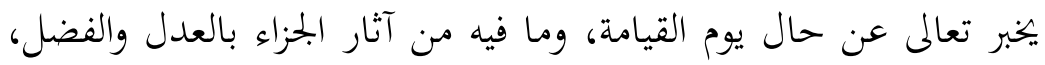
ويتضمن ذلك الترغيب والترهيب الموجب للخوف والرجاء، فقال: $\}$ وجوهو وهي وجوه أهل السعادة والخير، أهل الائتلاف والاعتصام بحبل الله، \}وتسود وجوه اسودت وجوههم بما في قلوبهم من الخزي والهوان والذلة والفضيحة، وأولئك ابيضت وجوههم، لما في قلوبهم من البهجة والسرور والنعيم، والحبور الذي ظهرت آثاره على وجوههم كما قال تعالى: \}ولقاهم نضرة وسرورا\{ نضرة في وجوههم وسرورا في قلوبهم، وقال تعالى: \{والذين كسبوا السيئات جزاء سيئة بمثلها وترهقهم ذلة كأنما أغشيت وجوههم قطعا من الليل مظلما أولئك أصحاب النار هم فيها خالدون \{ $\}$ فأما الذين اسودت وجوههم ج\{ فيقال لهم على وجه التوبيخ والتقريع: \}أكفرتم بعد إيمانكم \{ أي: كيف آثتتم الكفر والضلال على الإيمان والهدى؟ وكيف تركتم سبيل الرشاد وسلكتم طريق الغي؟ \}فذوقوا العذاب بما كنتم تكفرون \}وأما الذين ابيضت وجوههمر\{ فيهنئون أكمل تُنئة، ويبشرون أعظم بشارة، وذلك أهم يبشرون بدخول الجنات ورضى ربهم ورحمته \}فني رحمة الله هم فيها خالدون وإذا كانوا خالدين في الرحمة، فالجنة أثر من آثار رحته تعالى، فهم

خالدون فيها بما فيها من النعيم المقيم والعيش السليم (1). بعد أن يقضي الله بين الحلائق، وينتهي الحساب، وينجي الله المؤمنين من النار برحته، ويطهرهم من شوائب الدنيا من غلٍ، أو غيره، يأمرهم اللهـعز وجل بأن يدخلوا الجنة، خالدين فيها، فلا يموتوا، ولا يصيبهم هم، أو كدر.... فيعرف كل مؤمن بيته في الجنة، كما كان يعرف بيته في الدنيا. 


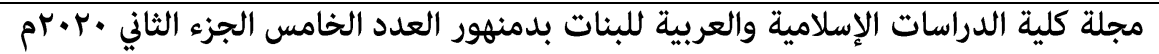
عن أبي سعيد الخندري رضي الله عنه، عن رسول الله صلى الله عليه وسلم قال: " إذا خلص المؤمنون من النار حبسوا بقنطرة بين الجنة والنار، فيتقاصون مظالم كانت بينهم في الدنيا حتى إذا نقوا وهذبوا، أذن لمم بدخول الجنة، فوالذي نفس محمد بيده، لأحدهم بمسكنه في الجنة أدل بمنزله كان في الدنيا (1).

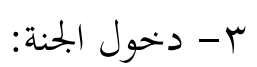

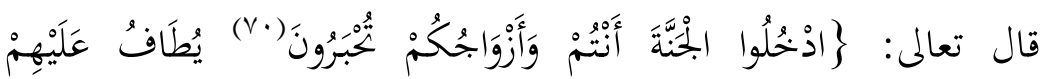

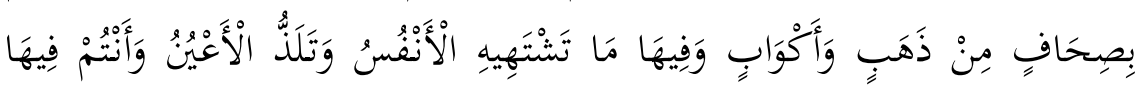

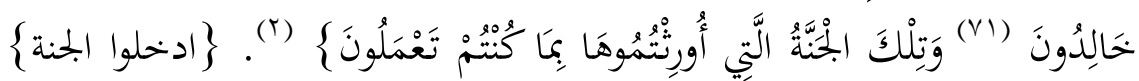
التي هي دار القرار \}أنتم وأزواجكم \{ أي: من كان على مثل عملكم، من كل مقارن لكم، من زوجة، وولد، وصاحب، وغيرهم.

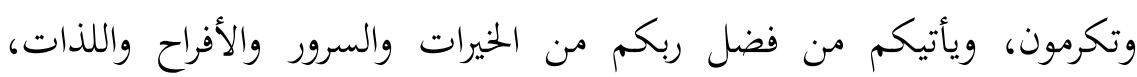
ما لا تعبر الألسن عن وصفه.... \} التي أورثتموها بما كنتم تعملون \{ أي: أورثكم الله إياها بأعمالكم، وجعلها من فضله جزاء لما، وأودع فيها من رحته ما أودع (r). عن أبي سعيد الخدري، قال: قال رسول الله صلى الله عليه وسلم: " إن أن أنه الله تبارك وتعالى يقول لأهل الجنة: يا أهل الجنة؟ فيقولون: لبيك ربنا وسعديك، فيقول: هل رضيتم؟ فيقولون: وما لنا لا نرضى وقد أعطيتنا ما لم تعط أحدا من خلقك، فيقول: أنا أعطيكم أفضل من ذلك، قالوا: يا رب، وأي شيء أفضل من ذلك؟ فيقول: أحل عليكم رضواني، فلا أسخط عليكم بعده أبدا " (ع).

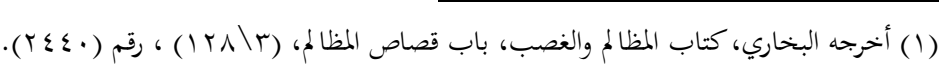

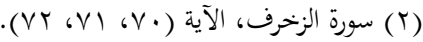

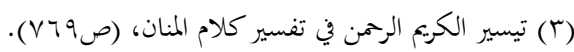

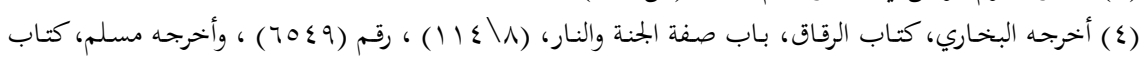

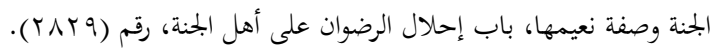




\section{لقاء الله في القرآن الكريم ( دراسة موضوعية )}

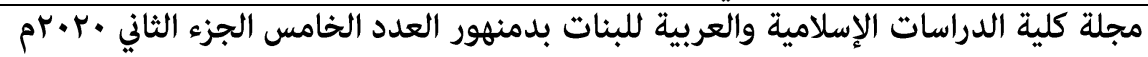
(إن الله تعالى يقول لأهل الجنة: يا أهل الجنة) إضافتهم إليها لتشريفه لهم بها ولم يقل: يا عبادي، ولا يا أهل الإيمان؛ لأن أهل الجنة أشرف من الوصفين وأخص إذ هم المؤمنون الذين خرجوا عن الذنوب فأدخلوا الجنة (فيقولون لبيك ربنا وسعديك والخير في يديك) تقدم الكالام على هذين اللفظين (فيقول

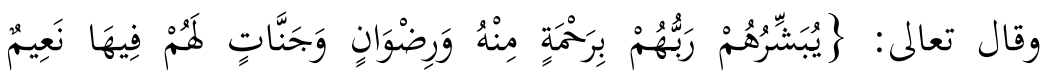

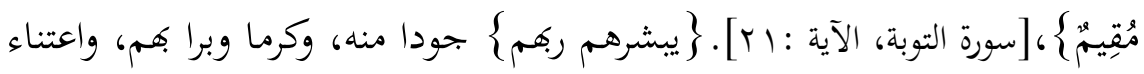
ومحبة لهم، \} برحة منه \{ أزال بها عنهم الشرور، وأوصل إليهم بها كل خير، \}ورضوان \{ منه تعالى عليهم، الذي هو أكبر نعيم الجنة وأجله، فيحل عليهم رضوانه، فلا يسخط عليهم أبدا، \}وجنات لهم فيها نعيم مقيم اشتهته الأنفس، وتلذ الأعين، محا لا يعلم وصفه ومقداره إلا الله تعالى، الذي منه أن الله أعد للمجاهدين في سبيله مائة درجة، ما بين كل درجتين كما بين السماء والأرض، ولو اجتمع الخلق في درجة واحدة منها لوسعتهم (1).

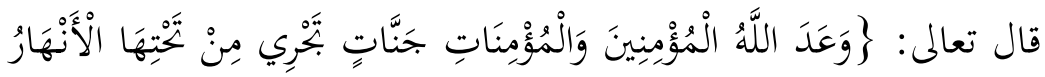

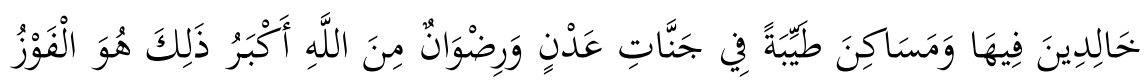

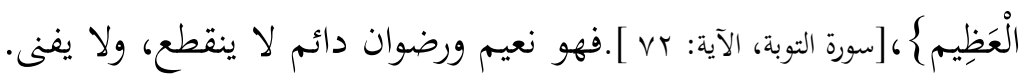
نتائج عدم لقاء الكافرين ربهم 1 - مـن أبرز نتـائج لقـاء الله تعـالى أهـم عـن ربهـم ذاك اليوم حجوبـون. قـال الله تعـالى: $\}$ فأعظم عقاب لمؤلاء هو حرماهمم من رؤية الله تعالى يوم القيامة، فلا يرونه؛ لأفمم بإنكارهم لقاء الله وأكسـابهم القبيحة صارت مرآة قلوبهم ذات صدأ،

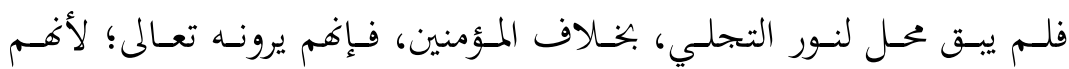




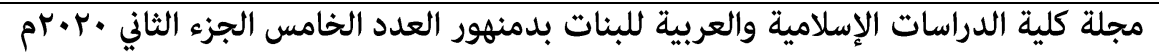

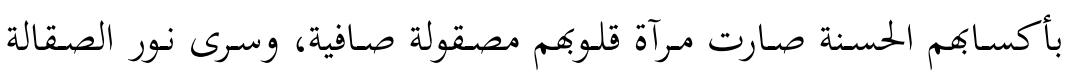
والصفوة منها إلى قوالبهم، فصاروا مستعدين لانعكاس نور التجلي في قلوبكم وقوالبهم، وصاروا وجوهًا من جميع الجهات، بل أبصارًا بالكلية (1).

$$
\text { ب-مقت الله لهم وإدخالهم النار : }
$$

قال الله تعالى:

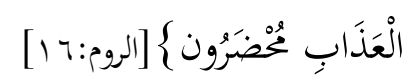

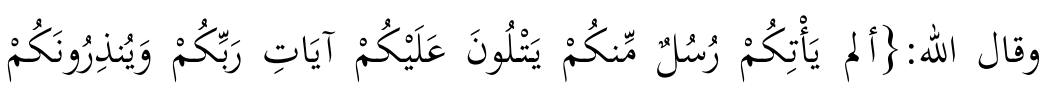

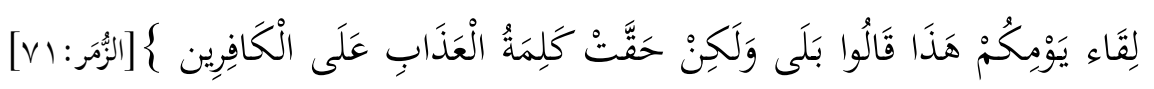
• قال العلامة ابن القيم: "وكلمته . سبحانه ـ إنما حقت عليهم بالعذاب بسبب كفرهم فحقت عليهم حجته، وكلمة عدله بعقوبته(؟). وقال الله تعالى:

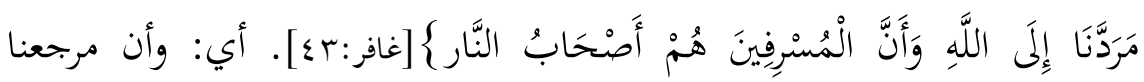

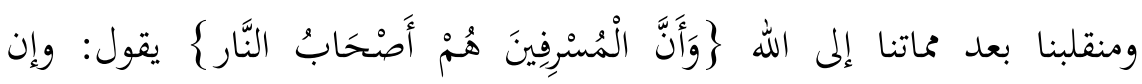

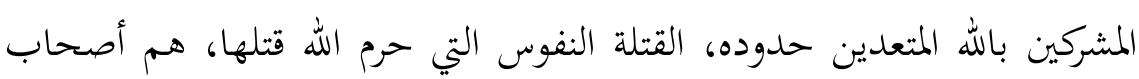
نار جهنم عند مرجعنا إلى الله (").

(1) تفسير حدائق الروح والريحان في روابي علوم القرآن، الشيخ العلامة محمد الأمين بن عبد الله الأرمي العلوي الهرري

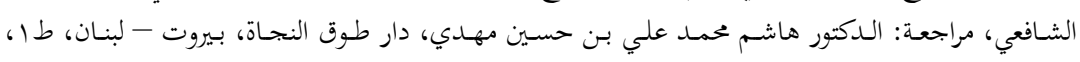

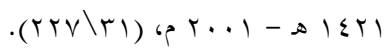

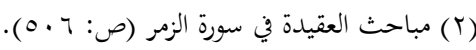

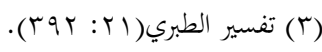




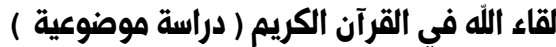

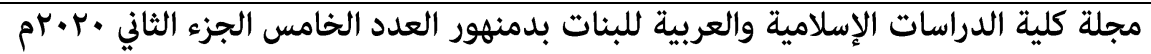

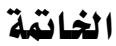

$$
\text { وقد اشتملت على أهم النتائج التي توصل إليها البحث. }
$$

الحمد الله الذي بنعمته تتم الصالحات، فقد يسر الله تعالى إتمام هذا

البحث بعد إتمامه ثم نقضه ثم إعادة بنائه محا تطلب وقتا طويلا، وقد توصلت إلى

$$
\text { نتائج عدة وأنا أذكر أهمها: }
$$

1 - بلغت الإطالاقات اللفظة للقاء الله أكثر من عشرين لفظة مختلفة، للمصدر

$$
\text { منها: } 7 \text { ا وللمصدر الميمي } 7 \text { مواضع، والمضارع موضعان. }
$$

r- بلغت الإطلاقات المعنوية للقاء الله تعالى أكثر من ثلاثين موضعا جاء فيبعضها لقاء الآخرة، وبعضها لقاء يومهم، وبعضها بالاستقرار عند اللهن وغلى الله، والفرار إليه، ونخو ذلك محا يدلن حيث المعنى على لقاء الله

$$
\text { تعالى. }
$$

ب- جاءت نصوص عدة بإثبات لقاء الله تعالى من الآيات القرآنية والأحاديث

$$
\text { النبوية محا لا يدع في المسألة شكا. }
$$

ع- - بيجوز رؤية الله في الدنيا لطلب موسى عليه السلام ذلك، لكنه لم يقع، واختلفوا في رؤية النبي صلى الله عليه وسلم ربه ليلة المعراج، والراجح أنه رآه

$$
\text { بقلبه لا بعين رأسه. }
$$

ه - اتفق المسلمون على أن البي صلى الله عليه وسلم رأى ربه في المنام للأحاديث الواردة في ذلك، ويبكوز حتى للمؤمنين على القول الراجح. ج- - كان من نتائج لقاء الله تعالى ولازمه رؤية الله تعالى، وقد وردت أدلة أخرى

$$
\text { والله تعالى أعلم وصلى لقاء الله تعالى على رؤيته يوم القيامة. }
$$




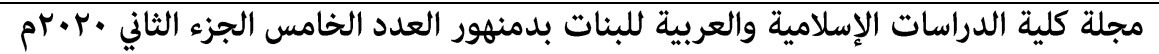

\section{المراجع والمصادر}

ا ـ الإبانة عن أصول الديانة، لـ أبو الحسن علي بن إسماعيل بن إسحاق بن سالم

بـن إسماعيـل بـن عبــ الله بـن موسى بـن أبي بـردة بـن أبي موسىى الأشعري

(المتوفى: ع باهـ)، تحقيق: د. فوقيـة حسـين محمود، الناشر: دار الأنصار -

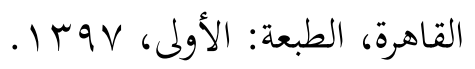

Y. البيهقي وموقفـه مـن الإلميـات، لـ أحمـد بـن عطيـة بـن علي الغامـدي، عمـادة البحث العلمي بالجامعة الإسلامية، المدينة المنورة، المملكة العربية السعودية،

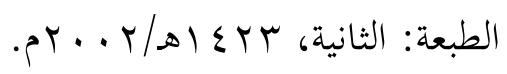

ب. تفسـير القـرآن العظيم لابسن أبي حـاتم، أبـو محمـد عبـد الرحمن بـن محمد بـن إدريس بن المنذر التميمي، الحنظلي، الرازي ابن أبي حاتم (المتوفى: V VTه)، تحقيـق: أسـعد محمــ الطيـبـ، مكتبـة نـزار مصـطفى البـاز -المملكـة العربيـة

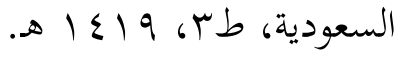
ع . تفسير القرآن العظيم، أبو الفداء إسماعيل بن عمر بن كثير القرشي البصري ثم الدمشقي (المتوفى: هV \& \&)، تحقيق: سامي بن محمد سالامة، دار طيبة للنشر

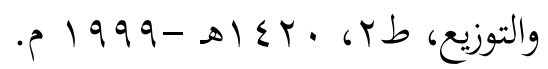

هـ تفسـير حــائق الـروح والريهـان في روابي علـوم القـرآن، الشـيخ العلامـة محمــ الأمـين بن عبـد الله الأرمي العلوي الهرري الشـافعي، مراجعة: الدكتور هاشـم

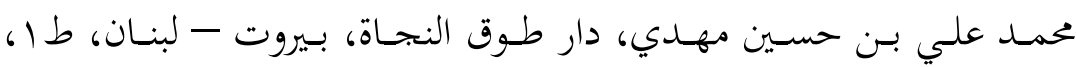

$$
\text { . }
$$

7. تفسير مقاتل بـن سليمان، أبو الحسـن مقاتل بـن سـليمان بـن بشـير الأزدي

البلخهى (المتـوفى: • م اهـ)، تحقيـق د: عبــ الله محمـود شـحاته، دار إحيـاء

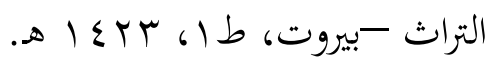




\section{لقاء الله في القرآن الكريم ( دراسة موضوعية )}

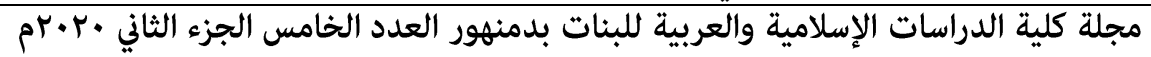

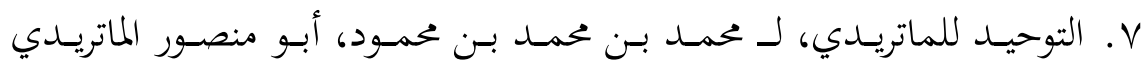
(المتوفى: بrسه)، تحقيق: د. فتح الله خليف، الناشر: دار الجامعات المصرية

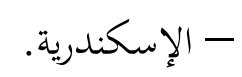

^. تيسير العزيز الحميد في شرح كتاب التوحيد الذى هو حق الله على العبيد، لـ

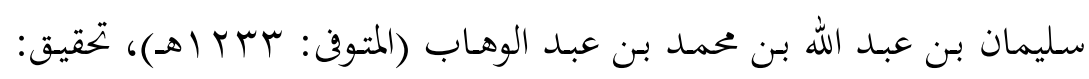

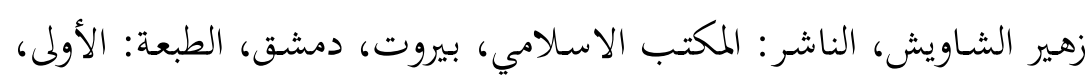

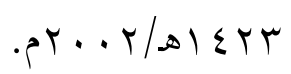

9. تيسير الكريم الرحمن في تفسير كلام المنان، عبد الرحمن بن ناصر بن عبد الله

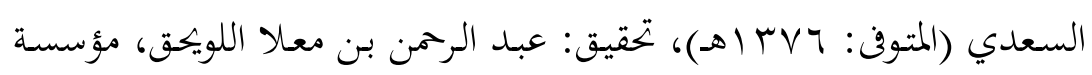

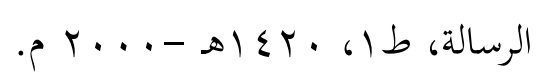

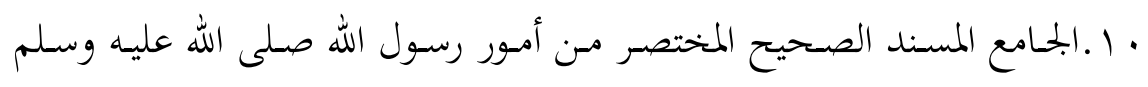

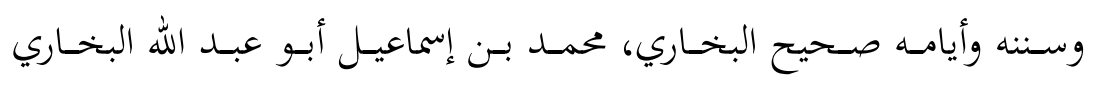
الجعفي، تحقيـق: محمــ زهـير بـن ناصـر الناصـر، دار طـوق النجـاة، الطبعـة:

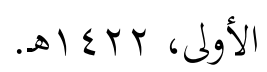

11 ـاعـاء العينـين في محاكمـة الأحمـدين، لـ نعمـان بـن محمـود بـن عبـد الله، أبـو

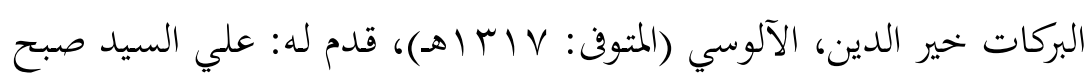

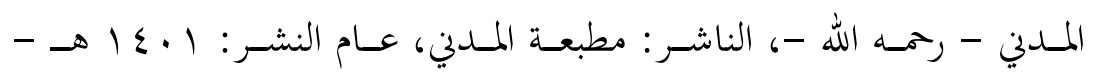

$$
\text { • } 1911
$$

با ـ الرد على الجهمية والزنادقة، لـ أبو عبد الله أحمد بن حمدد بن حنبل بن هلال

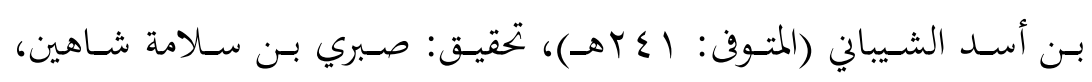
الناشر: دار الثبات للنشر والتوزيع، الطبعة: الأولى.

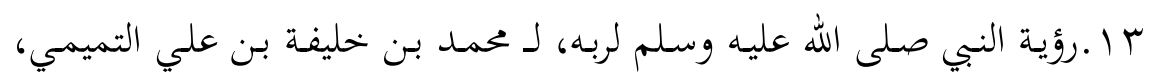

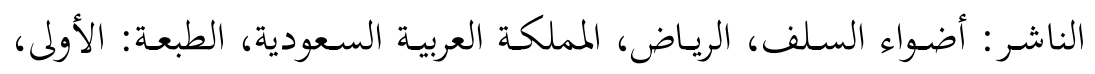

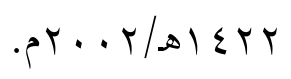




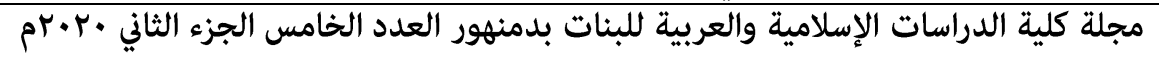

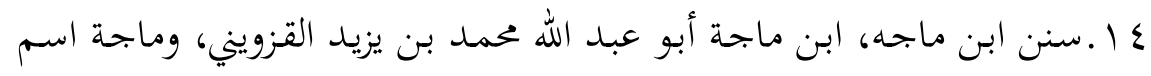

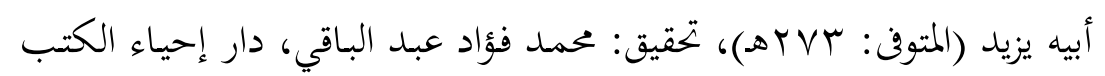

$$
\text { العربية -فيصل عيسى البابي الحل. }
$$

ه ـ شـرح السـنة، لـ أبسو محمــ الحسـن بـن علـي بـن خلـف البربهاري (المتـوفى:

. (s)

7 أشـرح الطحاويـة، لـ صـدر الـدين محمـد بـن عـاء الـدين علـيّ بـن محمـد ابـن

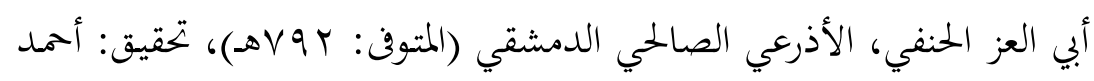

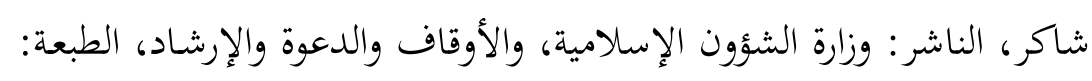

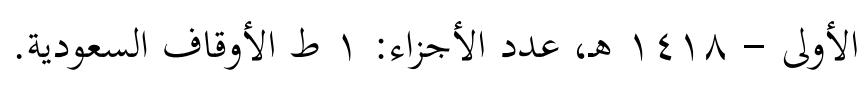

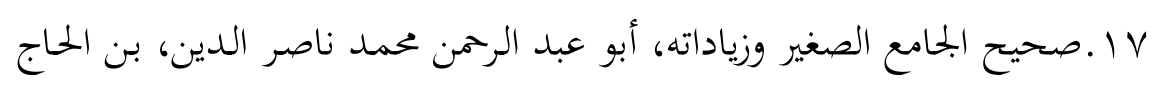

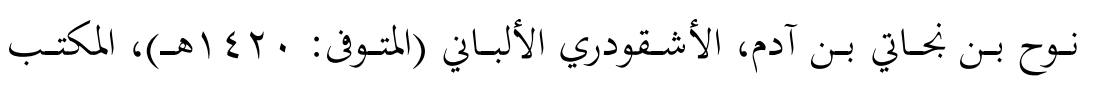

$$
\text { الإسالإمي. }
$$

1 1 ـالعواصـم والقواصسم في الذب عن سـنة أبي القاسـم، لـ ابن الوزير، محمد بن

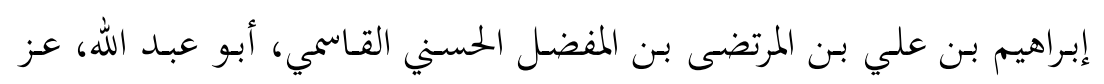

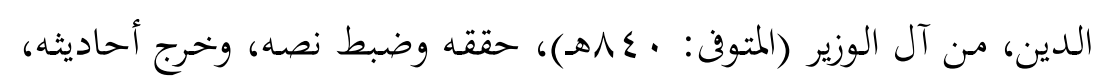

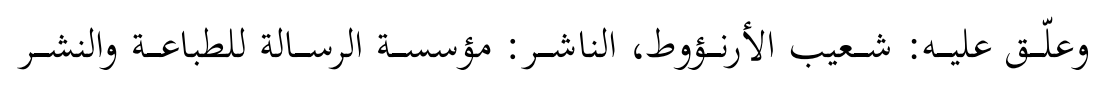

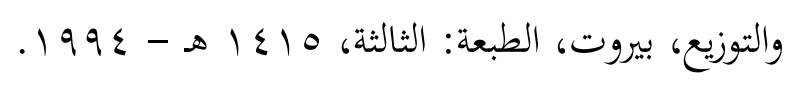

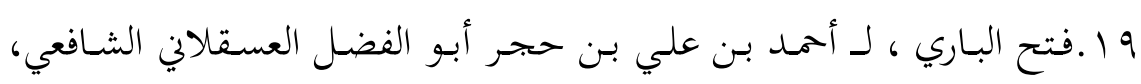
الناشر: دار المعرفة - بيروت، IrVq Iا، رقم كتبه وأبوابه وأحاديثه: محمد فؤاد عبد الباقي، قام بإخراجه وصححه وأشرف على طبعه: محب الدين الخطيب، عليه تعليقات العلامة: عبد العزيز بن عبد الله بن باز .

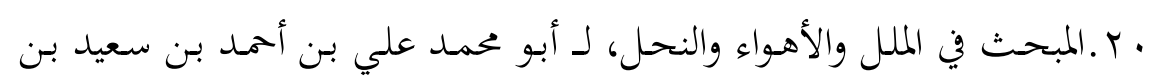

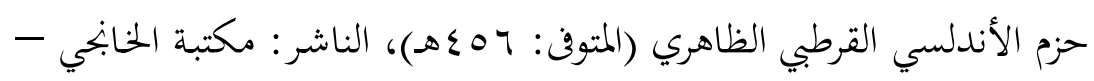
القاهرة. 


\section{لقاء الله في القرآن الكريم ( دراسة موضوعية )}

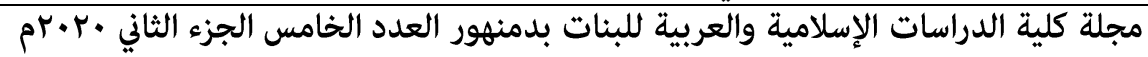

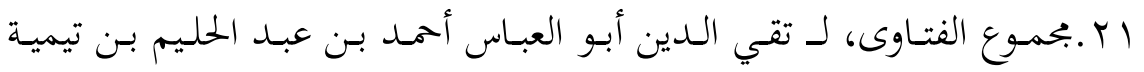

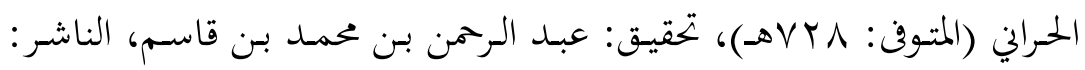

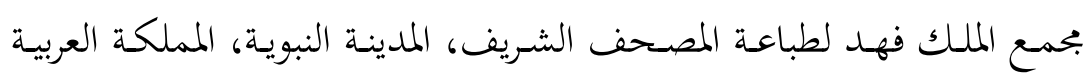

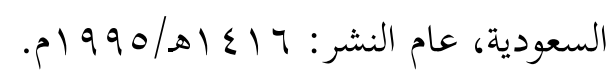

Tr المستدرك على الصحيحين، أبو عبد الله الحـاكم محمد بن عبد الله بن محمد

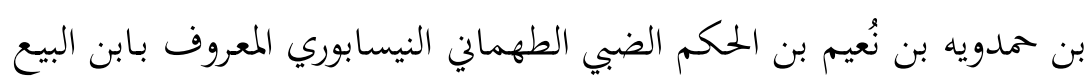
(المتوفى: ه . عهـ)، تحقيق: مصطفى عبد القـادر عطا، دار الكتبب العلمية -

$$
\text { بيروت، ط1 199. }
$$

بr .المسند الصحيح المختصر بنقل العدل عن العدل إلى رسول الله صلى الله عليه

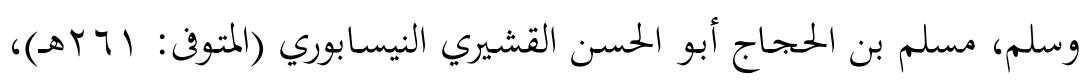

$$
\text { تحقيق: محمد فؤاد عبد الباقي، دار إحياء التراث العربي - بيروت. }
$$

ع ب. نقضض الإمـام أبي سعيد عثمـان بـن سعيد على المريسي الجهمهي العنيـ فيما

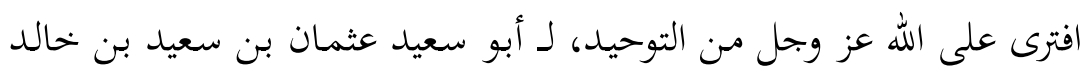
بن سعيد الدارمي السجستاني (المتوفن: م بهـ)،الناشر : مكتبة الرشد للنشر

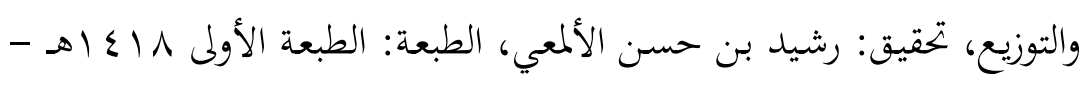
. 1991

هץ .الأسـاليب والإطلاقـات العربيسة، تـأليف: أبي المنـذر محمـود بـن محمـــ بـن مصطفى بن عبد اللطيف المنياوي، الناشر: الملكتبة الشاملة، مصر، الطبعة:

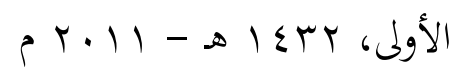

جץ بحر العلوم ـ تأليف: أبي الليث نصر بن محمد بن إبراهيم السمرقندي الفقيه الحنفي، دار النشر: دار الفكر - بيروت، تحقيق: د. محمود مطرجي. 


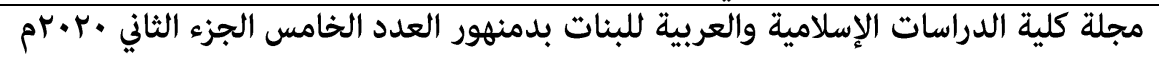

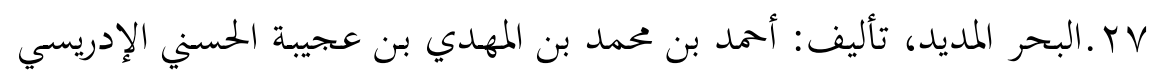
الشاذلي الفاسي أبي العباس، دار النشر / دار الكتب العلمية ـ بيروت، الطبعة

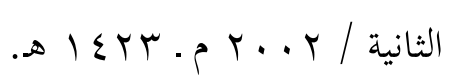

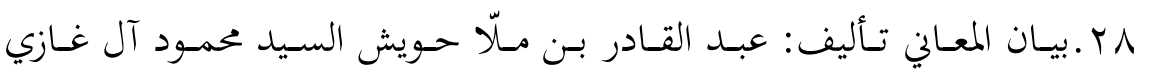

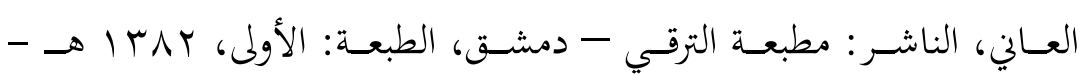

و ب التحرير والتنوير \اتحرير المعنى السديد وتنوير العقل الجلديد من تفسير الكتاب البحيـدها، تـأليف : محمـد الطـاهر بـن محمـد بـن محمـد الطـاهر بـن عاشـور التونسي، الناشر : الدار التونسية للنشر - تونس، سنة النشر: ع 19 أهـ

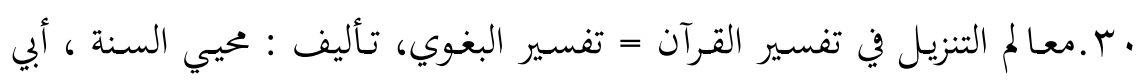
محمد الحسين بن مسعود بن محمد بن الفراء البغوي الشافعي. تحقيق : عبد

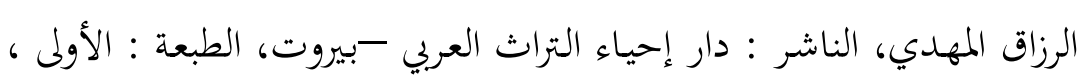
. $1 \leqslant Y$. اس.جامع البيان في تأويل القرآن، تأليف: محمد بن جرير بن يزيـد بن كثير بن غالـب الآملي، أبي جعفـر الطـبري ، المحتق: أحمـد محمــ شـاكر، الناشـر:

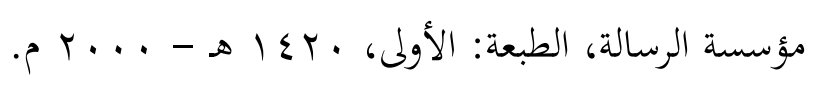

بr. التفسير الوسيط للقـرآن الكريم، تأليف: بحموعـة مـن العلمـاء بإشراف بحمـع البحـوث الإسـلامية بـالأزهر الناشـر: الهيئة العامـة لشـئون المطـابع الأميريـة،

$$
\text { الطبعة: الأولى، (بوس }
$$

سب.تنوير المقباس من تفسير ابن عباس، ينسب: لعبد الله بن عباس - رضي الله

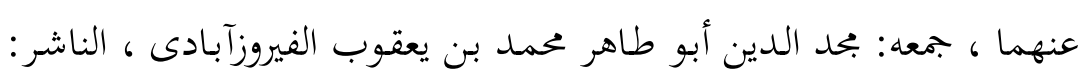

$$
\text { دار الكتب العلمية - لبنان. }
$$




\section{لقاء الله في القرآن الكريم ( دراسة موضوعية )}

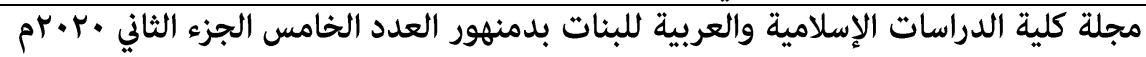

عَ.تهـذيب اللغـة، تـأليف: محمـد بـن أحمـل بـن الأزهـري الهـروي، أبـو منصـور ،

تحقيـق: محمـد عـوض مرعسب، الناشـر: دار إحيـاء الـتراث العـربي - بـيروت،

$$
\text { الطبعة: الأولى، } 1 \text { •. ب م. }
$$

هم. التوحيد وإثبات صفات الرب عز وجل، تأليف: أبوي بكر محمد بن إسحاق بن خزيمة بن المغيرة بن صالح بن بكر السلمي النيسابوري، تحقيق: عبد العزيز بـن إبراهيم الشهـوان، الناشر : مكتبـة الرشد - السعودية - الرياض، الطبعة:

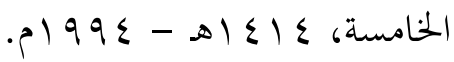

جب.توضيح المقاصد وتصحيح القواعد في شرح قصيدة الإمام ابن القيم، تأليف: أحمد بن إبراهيم بن حمد بن محمد بن حمد بن عبد الله بن عيسى ، تحقيق: زهـير الشـاويش، الناشـر: المكتـب ، لإسـلامي - بــيروت، الطبعـة: الثالثـة، $.1 \leq \cdot 7$

V r. سنن أبي داود لسليمان بن داود السجستاني، أبو داود. تعليق عزت الدعاس

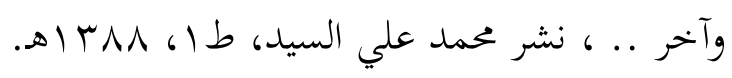

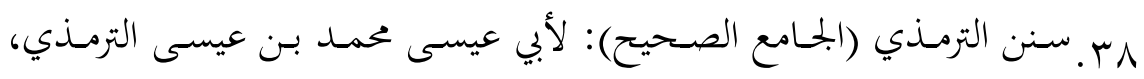
تحقيق: أحمد محمد شاكر، دار الكتب العلمية، بيروت. وم..شـرح الوصسية الكـبرى لابن تيميـة، تـأليف: عبـد العزيز بـن عبـد الله بـن عبـد الرحمن الراجحي، مصدر الكتاب: دروس صوتية قام بتفريغها موقع الشبكة http://www.islamweb.net الإسلامية • ع. العلل الواردة في الأحاديث النبوية. تأليف: أبي الحسن علي بن عمر بن أحمد بـن مهـدي بـن مسـود بـن النعمـان بـن دينـار البغـادي الــارقطني ، تحقيـق وتخريج: ححفوظ الرحمن زين الله السلفي، الناشر: دار طيبة - الرياض، الطبعة:

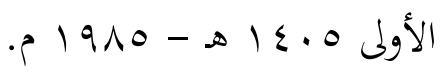




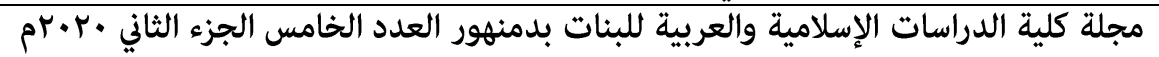

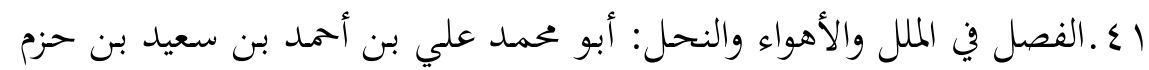
الأندلسي القرطبي الظاهري.

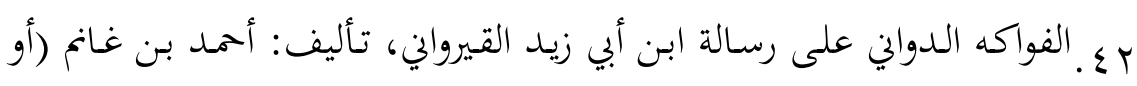
غنيم) بن سـالم ابن مهنـا، شهاب الدين النفراوي الأزهري المالكي، الناشر: دار الفكر، الطبعة: بدون طبعة، تاريخ النشر: 10 بـ ـالكافية الشـافية في الإنتصار للفرقة الناجيـة (نونية ابن القيم)، تأليف: محمد بن أبي بكر بن أيوب ابن قيم الجوزية، تحقيق: محمد بن عبد الرحمن العريفي | ناصر بـن يجيى الجنيني | عبد الله بـن عبد الرحمن الهذيل | فهد بـن علي

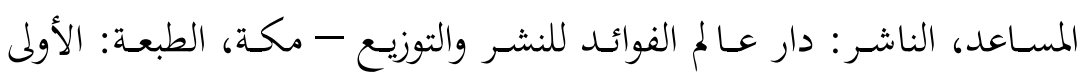
$.8 \leqslant Y \Lambda$

§ ـ.لسان العرب، لابن منظور حممد بن مكرم الناشر: دار صادر، بيروت، ط اه . $) 99 \mathrm{~V}$ ○ـ .لطائف الإشارات = تفسير القشيري، تأليف: عبد الكريم بن هوازن بن عبد الملـك القشـيري ، تحقيـق: إبـراهيم البسـيوني، الناشـر: الهيئسة المصسرية العامـة للكتاب ، مصر، الطبعة: الثالثة.

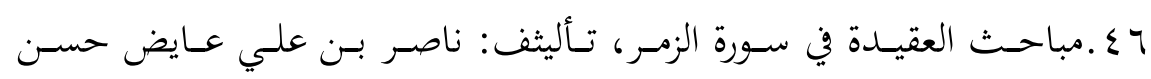
الشـيخ، الناشـر : مكتبـة الرشـد، الريـاض، المملكـة العربيـة السعودية، الطبعـة:

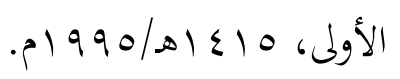

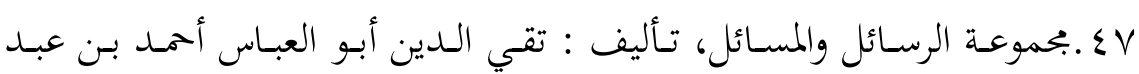

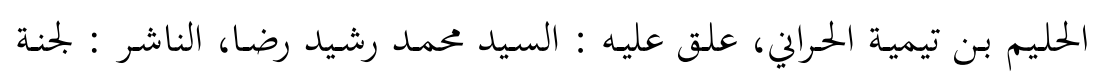

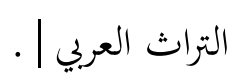




\section{لقاء الله في القرآن الكريم ( دراسة موضوعية )}

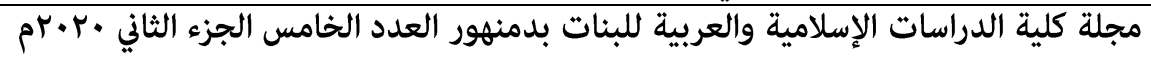

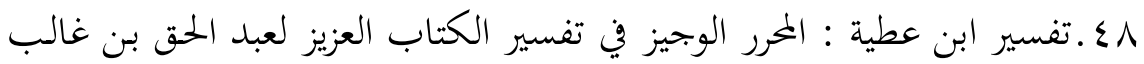
بن عبد الرحمن بن تمام بن عطية الأندلسي المحاربي أبو محمـد. تحقيق: عبـد السالام عبد الشافي محمد.، ، الناشر: دار الكتب العلمية - بيروت. الطبعة:

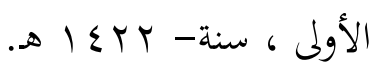

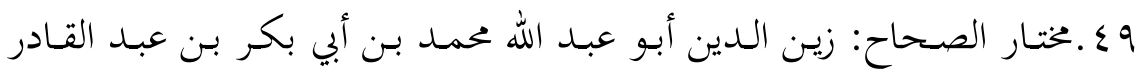

• ه. مسند الإمام أحمد بن حنبل = الموسوعة الحديثية، إشراف الدكتور: عبد الله عبد المحسن التركي، والشيخ شعيب الإرنؤوط، وشارك في تحقيقه بحموعة من

$$
\text { الباحثين، مؤسسة الرسالة، الطبعة الأولى سنة(الب ع (هـ) }
$$

اهـ المعجم الكبير: لأبي القاسم سليمان بن أحمد الطبراني ، تحقيق : حمدي بن عبدالبحيد السلفي ، الطبعة الثانية،(ع ع اهـ)مكتبة العلوم والحكمم، الموصل. به المعجـم الوسيط، تـأليف: بحمـع اللغـة العربيـة بالقـاهرة، (إبـراهيم مصعفى / أحمد الزيات / حامد عبد القادر / محمد النجار)، الناشر: دار الدعوة. به .معجــم مقـاييس اللغـة : لأبي الحسـين أحمـد بـن فـارس بـن زكريـا، تحقيـق : عبد السلام هارون ، الطبعة الأولى (1 (1) إهـ ، دار الجيل . عه .الوصية الكـبرى = رسالة شيخ الإسلام ابن تيمية إلى أتباع عدي بن مسافر الأمـوي، تأليف: شيخ الإسـلام أبو العباس أحمـد بن عبد الحليم ابن تيمية، تحقيق: حمدد عبد الله النمر - عثمان جمعة ضميرية، الناشر: مكتبة الصديق - الطائف، الطبعة: الأولى، م · ع اهـ - $191 V$ ام. 
لقاء الله في القرآن الكريم ( دراسة موضوعية )

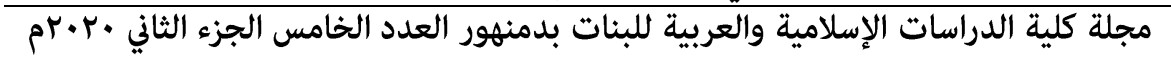

